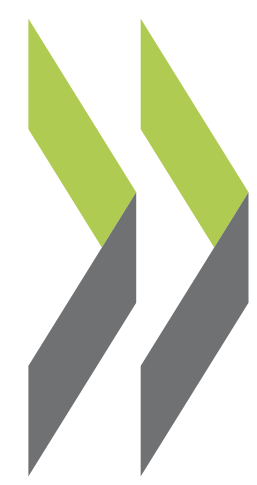

OECD Economics Department Working Papers No. 313

\author{
Increasing Efficiency \\ and Reducing Complexity \\ in the Tax System \\ in the United States
}

Richard Herd, Chiara Bronchi 
ECONOMICS DEPARTMENT

INCREASING EFFICIENCY AND REDUCING COMPLEXITY IN THE TAX SYSTEM IN THE UNITED STATES

ECONOMICS DEPARTMENT WORKING PAPERS No. 313

by

Richard Herd and Chiara Bronchi 


\title{
ABSTRACT/RÉSUMÉ \\ INCREASING EFFICIENCY AND REDUCING COMPLEXITY IN THE TAX SYSTEM IN THE UNITED STATES
}

\begin{abstract}
There are only a few OECD Member countries with a lower tax take than the United States. Nonetheless there are a number of improvements that could help reduce the distortions that taxation creates in the economy and so boost long-run economic performance. The most noticeable gains could come from reforming the taxation of the income from capital. Savings are not always allocated to the area where they have the highest return, as there are large variations in the tax on capital income depending on the sector in which it is invested and the financing instruments that are used. In addition, taxation of capital income favours present over future consumption with a negative impact on savings and capital accumulation. In the past, a number of proposals have been made to reduce the tax burden on saving, by replacing the income tax with a consumption tax. While in many ways this would be the best approach, it is would represent a major change in a system that has evolved gradually and, therefore, is unlikely to be undertaken. A more likely alternative direction for change, that could also generate benefits, would be to lower the taxation of capital income by reducing corporate tax rates, integrating the taxation of corporations and individuals and cutting the capital gains tax rate. Efficiency gains might also flow from lowering the top marginal tax rates on income and extending the scope of saving schemes that allow tax-free accumulation of income until the money is spent.
\end{abstract}

JEL classification: $\mathrm{H} 2$

Keywords: taxation, tax policy, United States

\section{VERS UNE FISCALITE PLUS EFFICIENTE ET MOINS COMPLEXE}

Il n'y a seulement que quelques pays membres qui ont des recettes fiscales moindres que celles des États-Unis. Néanmoins, il y a un certain nombre d'améliorations qui pourraient aider à réduire les distorsions créées par la fiscalité dans l'économie et dynamiser ainsi les performances économiques à moyen terme. Les gains les plus sensibles pourraient venir de la réforme de l'imposition du capital. L'épargne n'est pas toujours affectée aux domaines offrant les rendements les plus élevés, de grandes disparités existant selon les secteurs dans lesquels elle est investie et les instruments financiers qui sont utilisés. En outre, l'imposition des revenus du capital favorise la consommation présente plutôt que la consommation future avec un impact négatif sur l'accumulation de l'épargne et du capital. Dans le passé, un certain nombre de propositions avaient été faites pour réduire le fardeau de la fiscalité sur l'épargne en remplaçant l'imposition sur le revenu par une imposition de la consommation. Même si à bien des égards cette approche est la meilleure, elle représenterait un changement majeur pour un système qui a évolué graduellement et il est donc peu probable qu'elle soit retenue. Une alternative plus vraisemblable, qui pourrait générer aussi des avantages, serait de réduire l'imposition des revenus du capital en baissant le taux d'imposition sur les sociétés, en combinant la fiscalité des sociétés et des personnes physiques et en diminuant le taux d'imposition sur les plus-values. On pourrait également dégager des gains d'efficience en baissant les taux d'imposition marginaux sur le revenu les plus élevés et en élargissant les limites des programmes d'épargne qui permettent une accumulation de revenus exonérés d'impôt.

Classification JEL : $\mathrm{H} 2$

Mots clés : fiscalité, politique fiscale, États-Unis

\section{Copyright $\odot$ OECD 2001. All rights reserved.}

Applications for permission to reproduce or translate all, or part of, this material should be made to: Head of Publications Service, OECD, 2 rue André-Pascal, 75775 PARIS CEDEX 16, France 


\section{TABLE OF CONTENTS}

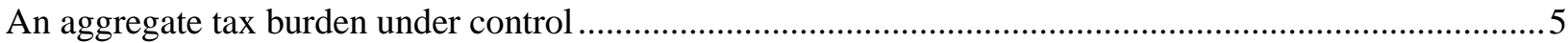

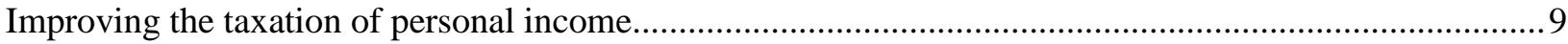

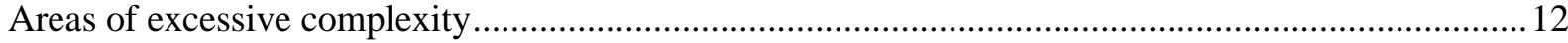

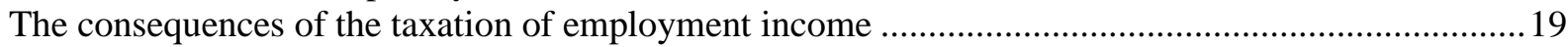

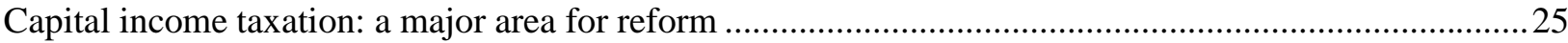

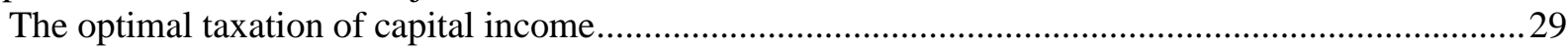

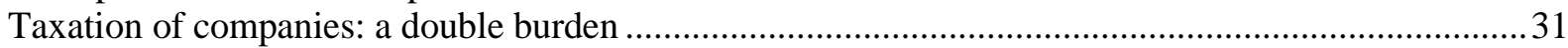

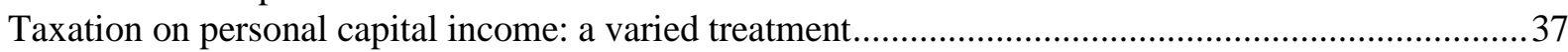

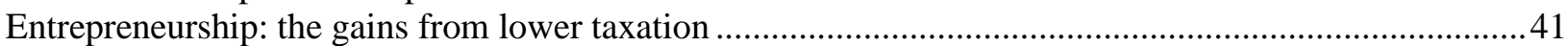

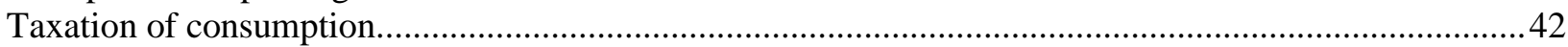

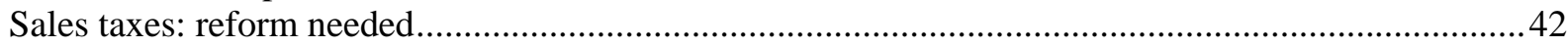

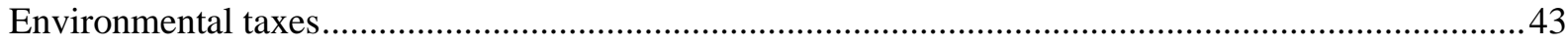

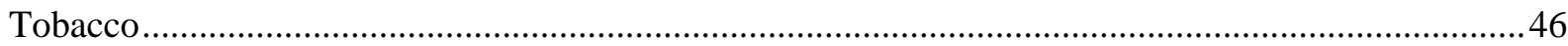

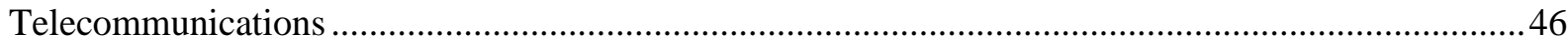

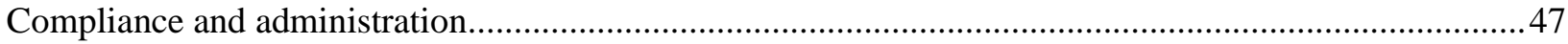

Assessment of past changes and recommendations for action............................................................48

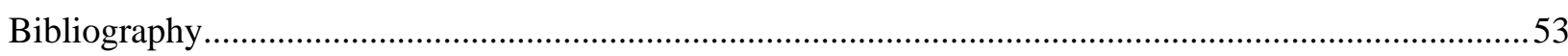

Annex

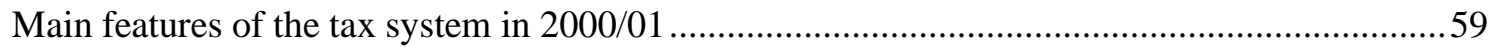

Boxes

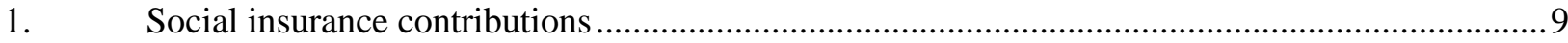

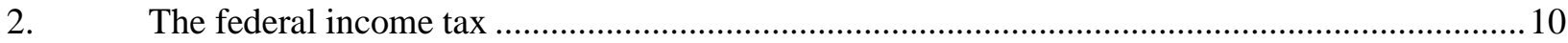

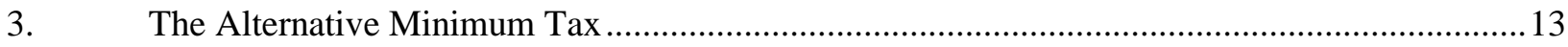

4. Benefits and costs from shifting to a consumption tax ..........................................................29

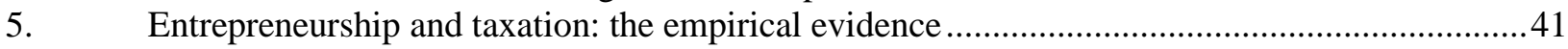

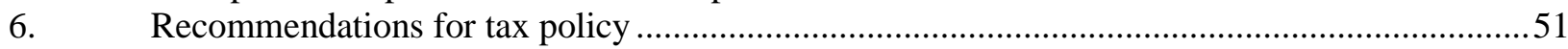

\section{Tables}

1. Personal income taxation in selected OECD countries. .11

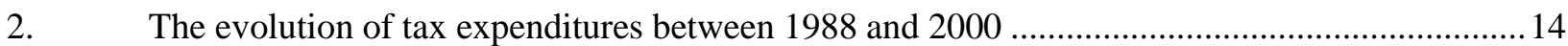

3. The biggest and most rapidly growing tax expenditures .......................................................15

4. The distribution of revenue loss for selected tax expenditures by income category ...................16

5. Statutory tax rates and marginal effective tax rates ................................................................... 17

6. Marginal effective tax rates for different family types ..........................................................2

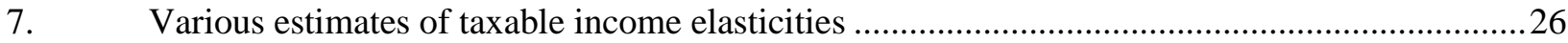

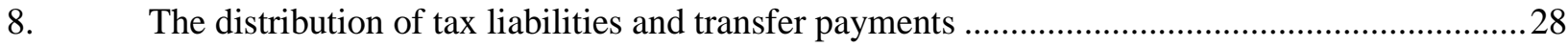

9. Net income of business enterprises and corporate tax payments ...............................................33

10. Marginal effective corporate tax wedges in manufacturing by source of financing ....................35

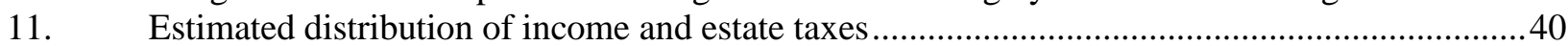

12. Taxes and fees on motor vehicles compared to costs generated by motor vehicles ...................45

13. Carbon dioxide emissions by fuel and current tax status......................................................... 46 
A1. State individual and corporate income taxes: top marginal rates 63

A2. Some state tax rates

\section{Figures}

1. Tax-to-GDP ratios in selected OECD countries and regions.................................................... 6

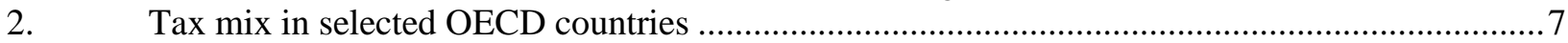

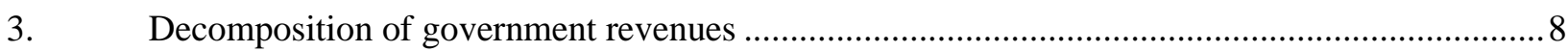

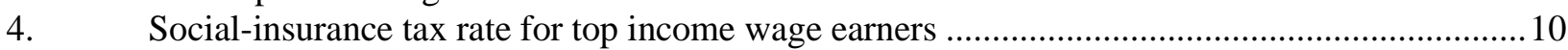

5. Highest combined social insurance and personal income tax rate ............................................ 12

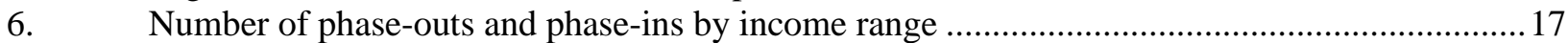

7. CEO pay and risk-adjusted pay for major US companies ..................................................... 18

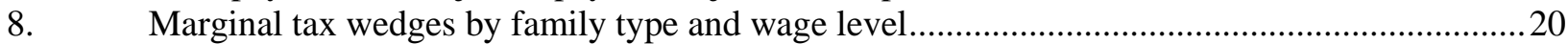

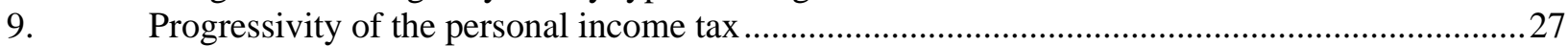

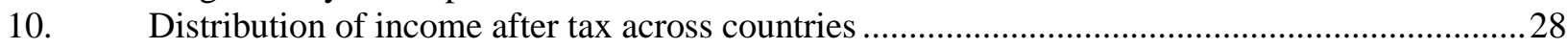

11. Number of limited liability entities by structure and tax regime ............................................... 31

12. Taxation of corporate income in OECD countries ..................................................................... 34

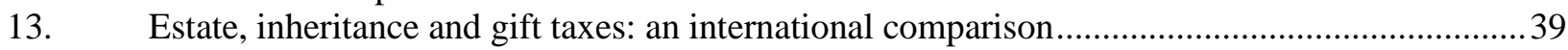

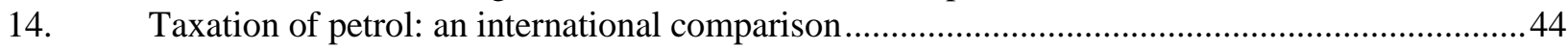


ECO/WKP(2001)39

\title{
INCREASING EFFICIENCY AND REDUCING COMPLEXITY IN THE TAX SYSTEM IN THE UNITED STATES
}

\author{
Richard Herd and Chiara Bronchi ${ }^{1}$
}

\section{An aggregate tax burden under control}

1. The total amount of tax revenue raised in the United States has increased only modestly over the past 35 years relative to GDP. Two periods of tax increases are apparent (Figure 1). The first occurred by design in the 1960s and 1970s, with a progressive broadening of social insurance programmes, the second occurred between 1993 and 2000, and was mainly unexpected. Overall, total federal revenues rose from 17.5 per cent of GDP in 1962 to 20.6 per cent in 2000. New legislation will remove almost half of this modest run-up, by lowering taxes by 1/1/4 percentage points of GDP when the cuts are fully implemented in 2010. Previous work in the OECD and elsewhere (Bassanini et al., 2001; Leibfritz, 1997; and Engen and Skinner, 1996) has suggested the average tax burden does influence the growth rate of the economy and so these cuts should boost the medium-term growth rate of the economy by a small but yet worthwhile amount. This chapter examines the areas where the tax structure could still be improved - especially as regards efficiency and complexity - as well as assessing some of the changes that have been made in the latest legislation. An overview of those changes and their budgetary consequences is given in OECD (2001).

2. Over the first 30 years, there has been a marked reduction in the highest statutory marginal rate of personal income taxation. The federal component of this rate fell from 70 per cent in 1980 to 28 per cent in 1986. Indeed, in many ways the reforms of 1986 were the most important tax legislation in this period, with statutory marginal rates being lowered, and the tax base widened, so that the overall changes were revenue neutral for personal and corporate taxation. Between 1986 and 2000, tax changes tended to reverse the reforms of 1986, with the highest statutory federal tax rate being raised to 39.6 per cent, while the personal tax base was narrowed. The latest tax reform will unwind some of the structural changes that have occurred in the past decade by reducing higher statutory marginal tax rates. At the same time, the recent reform will reduce the lowest statutory tax rate and raise tax credits for children. In the area of capital taxation, estate tax is to be phased out over time, while the gift tax rate is being reduced.

1. The authors are a senior economist and an economist at the OECD. This paper was originally produced for the OECD Economic Survey of the United States published in November 2001 under the authority of the Economic and Development Review Committee. The authors are indebted to Peter Jarrett, Mike Feiner, Jorgen Elmeskov, and Christopher Heady for comments and drafting suggestions, and to the US authorities for their assistance with obtaining the information and clarifications necessary to prepare the paper. Special thanks go to Françoise Correia, and to Mee-Lan Frank for technical assistance. 


\section{Figure 1. Tax-to-GDP ratios in selected OECD countries and regions}

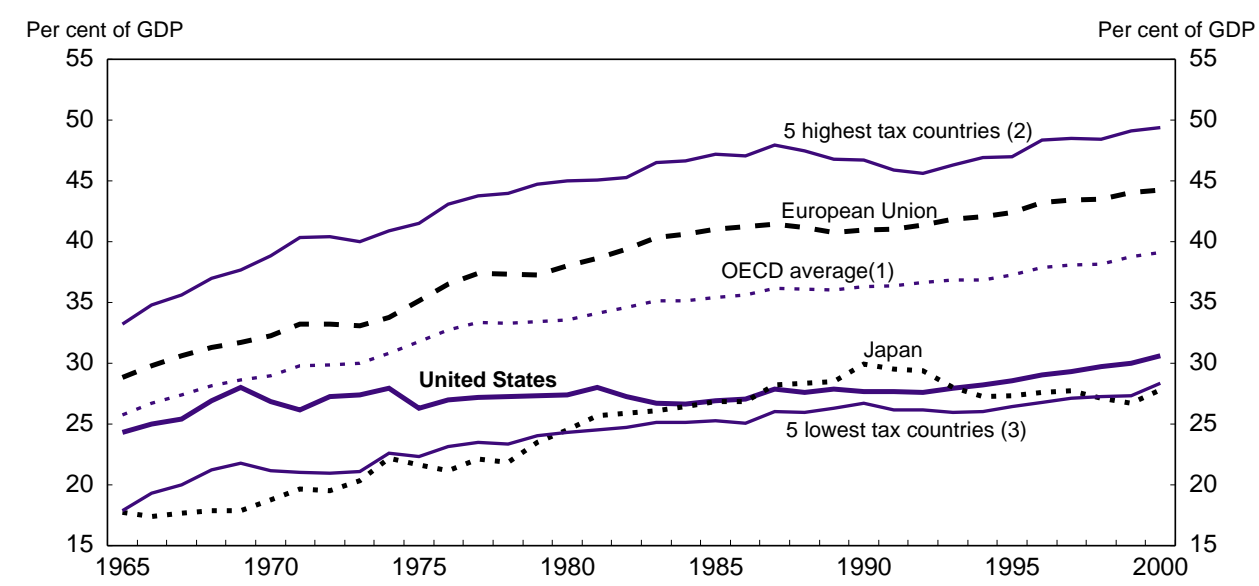

1. Unweighted average. Excluding Czech Republic, Hungary, Poland and Slovak Republic. Including Mexico from 1980.

2. 5 highest countries: Belgium, Denmark, France, Norway and Sweden.

3. 5 lowest countries: Australia, Japan, Korea, Mexico (from 1980) and United States.

Source: OECD.

3. Despite the small increase in the overall general government tax ratio, the level of overall taxation is low relative to other countries in the OECD area, representing slightly more than 30 per cent of GDP (Figure 1). As such, the distortive features of taxation are likely to be much lower than in most OECD countries. In 2000, the United States was close to the average for the five lowest countries and only four countries (Japan, Korea, Mexico and Turkey) raised less taxation. Personal income is the major source of taxation, more so than in the average OECD country (Figure 2). The share of social insurance taxes in total taxes is only slightly below the average in the area. The share of revenues raised from property taxes is high, reflecting the use of these taxes to pay for a number of local services, notably on education. By comparison, the share of revenues from the taxation of consumption is the second lowest and represents only half of the average share attributable to this particular base. The United States is the only OECD country not to have a national value-added tax and also has particularly low taxation on petrol, alcohol and tobacco.

4. The authority to raise taxation is very widely diffused, giving rise to significant tax competition between local areas that helps limit the burden of taxation. The constitution grants the states wide fiscal autonomy that enables each state to design a tax system that reflects the preferences of its citizens. State tax systems differ widely; this diversity extends to rates and bases and to the choice of which taxes to levy. ${ }^{2}$ More than 7000 sub-federal governments have the power to raise taxation, while individuals can always move if the burden from sub-federal taxation becomes too high, relative to benefits. Sub-federal authorities raised almost 31 per cent of all taxes in 2000. States account for the bulk of this, but nonetheless local governments account for one-third of non-federal tax receipts.

5. State and local government taxation has increased only slightly relative to GDP over the past 20 years. Most of the increase was concentrated in the 1980s. Since then sub-federal taxation has remained constant at just under 10 per cent of GDP. Such stability has occurred in the context of voters having the

2. For example, five states do not levy general sales taxes, seven have no personal income tax, and five do not levy a corporate income tax. 
possibility to challenge taxes by referenda and in an environment where many states face constitutional limits either on their ability to spend, tax or borrow. There is a certain degree of overlap in tax bases between the federal and the state and local governments, notably in the area of income taxation (Figure 3). The federal government draws most revenue from income taxation; state governments add a sales tax, while also taxing income. Finally, local governments raise most tax revenue from property taxes. State governments generally rely on the federal government for income assessment.

Figure 2. Tax mix in selected OECD countries ${ }^{1}$ 1999, per cent of total taxation
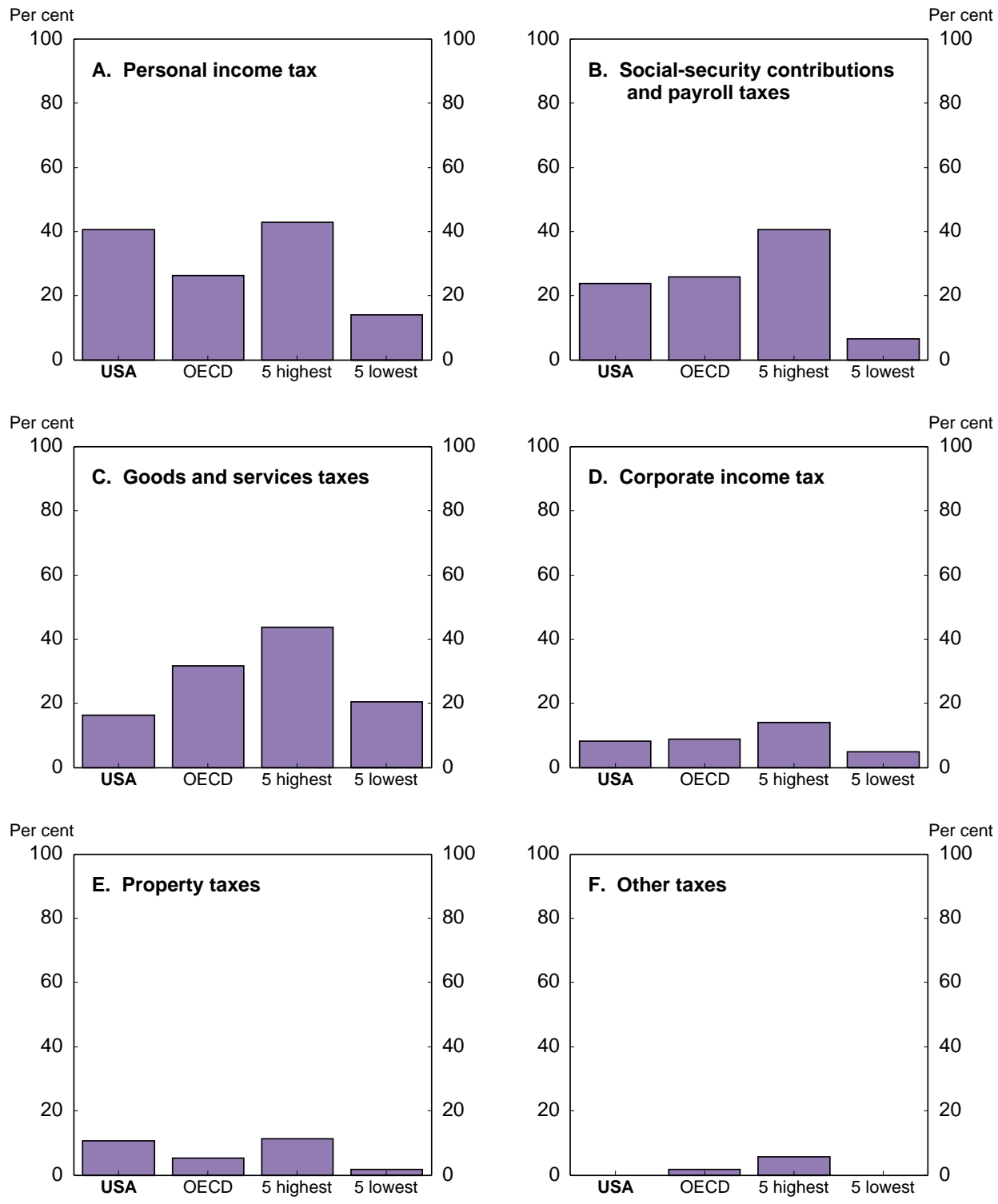

1. All averages are unweighted.

Source: OECD, Revenue Statistics (2001). 
Figure 3. Decomposition of government revenues

\section{A. Decomposition of federal government revenues, 2000}

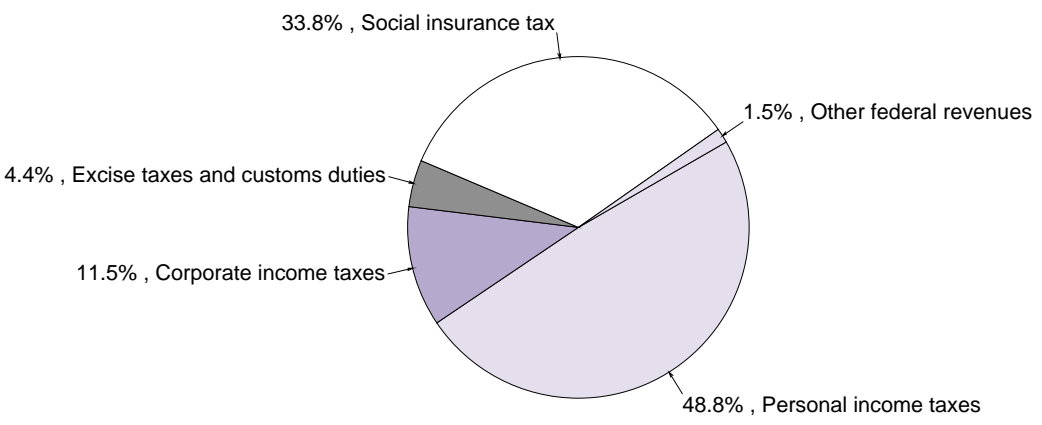

B. Decomposition of state government revenues, 1998-99

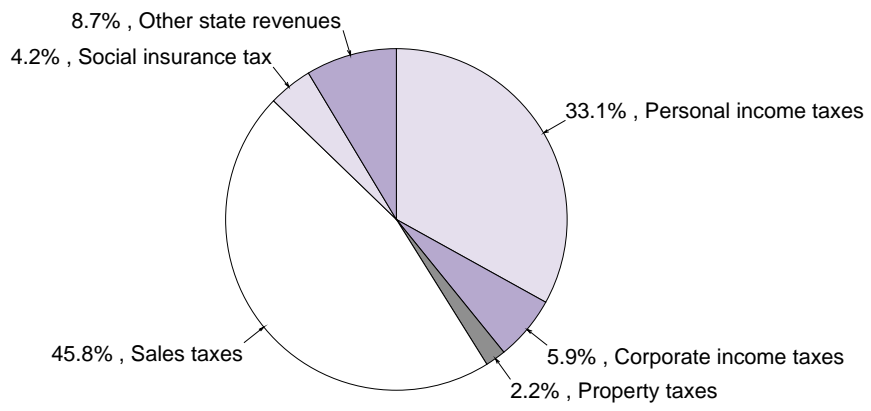

C. Decomposition of local government revenues, 1998-99

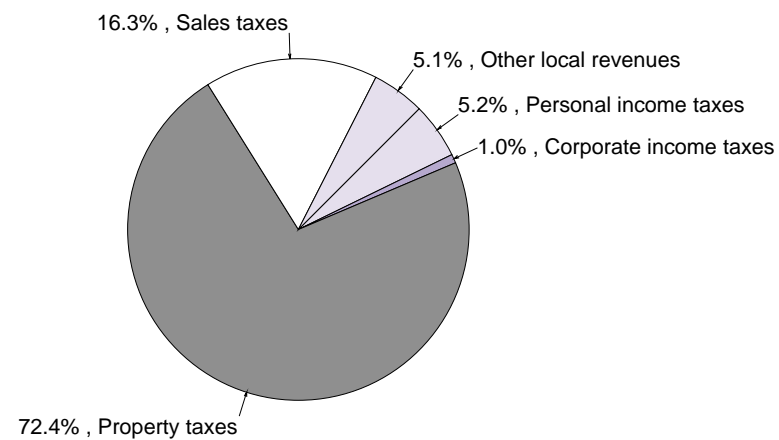

Source: Bureau of Economic Analysis and Bureau of the Census.

6. Despite the low and relatively stable level of government revenues, a number of concerns have been voiced about the tax system. First, it has become increasingly complex and, especially at the federal level, has been set a large number of tasks other than gathering a given amount of revenue in the most efficient way, though the federal government is obliged to quantify the cost of these deductions and include estimates of such tax expenditures in the annual budget documentation. Second, although many of the most adverse effects of taxation have been reduced with the progressive reduction of marginal income tax rates, adverse incentive effects remain in certain areas of the taxation of individual income. The area of capital income taxation is one where the system sits awkwardly between exempting such income from taxation 
altogether and a view that capital income should be taxed more heavily on distributional grounds. The rest of this chapter looks in more detail at the US tax system and makes some recommendations for its improvement.

\section{Improving the taxation of personal income}

7. Taxation of personal incomes represents by far the main source of revenue for governments in the United States. The system of personal income taxation is split into two parts: contributions to various social programmes that are generally proportional to labour income below a certain cap, and the personal income tax which is progressive and has increasing marginal rates. This group of taxes accounted for 81.8 per cent of federal revenues in 2000. Social Security contributions (and benefits) are subject to an overall income cap, beyond which no contributions are made or pensions paid. As a result, Social Security contributions and benefits decline as a proportion of income, as income moves beyond the cap. Although income tax rates do vary between states and to some extent local areas, the sub-federal authorities rely generally on the federal income tax system for the definition of income and enforcement. Moreover, the two systems are further linked since taxpayers have the right to deduct state and local income tax payments from their federal taxable income. Social insurance taxes are earmarked to finance specific programmes. This section does not deal with such social contributions in depth, as they were analysed in the context of population ageing in a recent Survey (OECD, 1999). Rather, it focuses on the design of the federal income tax system and the consequences for the economy of the changes in the relative prices that are induced by income taxation. Boxes 1 and 2 give broad details of the federal income and insurance tax system. Details of the whole system are to be found in the Annex.

\section{Box 1. Social insurance contributions}

Nearly all people in employment pay social-insurance taxes that serve to finance pensions and health care for the elderly. Old-age, survivors and disability pensions are financed by a tax of 12.4 per cent on annual wages up to a maximum of $\$ 80400$ in 2001. Health care for the elderly (Medicare) is partially financed by a tax of 2.9 per cent on all wages without limit. The tax is paid equally by employers and employees. Employers can deduct these payments from personal and corporate income tax, but employees cannot deduct them from personal income tax. The self-employed pay both the employee and employer components of the tax. They may deduct 50 per cent of their payments from gross income for federal income tax purposes, so putting them on the same basis as the employed, their payments amount to only 5.8 per cent of total social-security contributions. The share of payroll taxes in the federal fiscal revenues has risen in the past two decades. Indeed, by 1999, payroll tax payments exceeded income tax payments for 62 per cent of households, up from 44 per cent 20 years previously (Mitrusi and Poterba, 2000), with the yield of social insurance taxes rising form 5.5 to 6.7 per cent of GDP in the same period. Moreover, since, with the exception of Medicare contributions, social insurance contributions are subject to a ceiling, the rate for high wage earners is amongst the lowest within the OECD area (Figure 4). Of course, for some social insurance taxes there is a direct link between taxes and benefits. But, in the case of the United States, and more generally the financial return that is obtained from Social Security contributions is much lower than that can be obtained from capital markets. The difference in the rate of return on Social Security contributions and the return of investments in capital markets is due to the PAYGO (pay-as-you-go) structure of Social Security. The theoretical long-run rate of return of Social Security is the sum of growth rate of real wages and the labour force. This return will be less than the return on accumulating real capital, and, under certain circumstances the difference between these returns can exceed the gain to the initial generation that participated in the PAYGO system (Feldstein and Liebman, 2001). In addition, the US system of public pension benefits is redistributive, adding further to the extent to which the contributions are regarded as taxes. 


\section{Figure 4. Social-insurance tax rate for top income wage earners ${ }^{1}$ 1998}

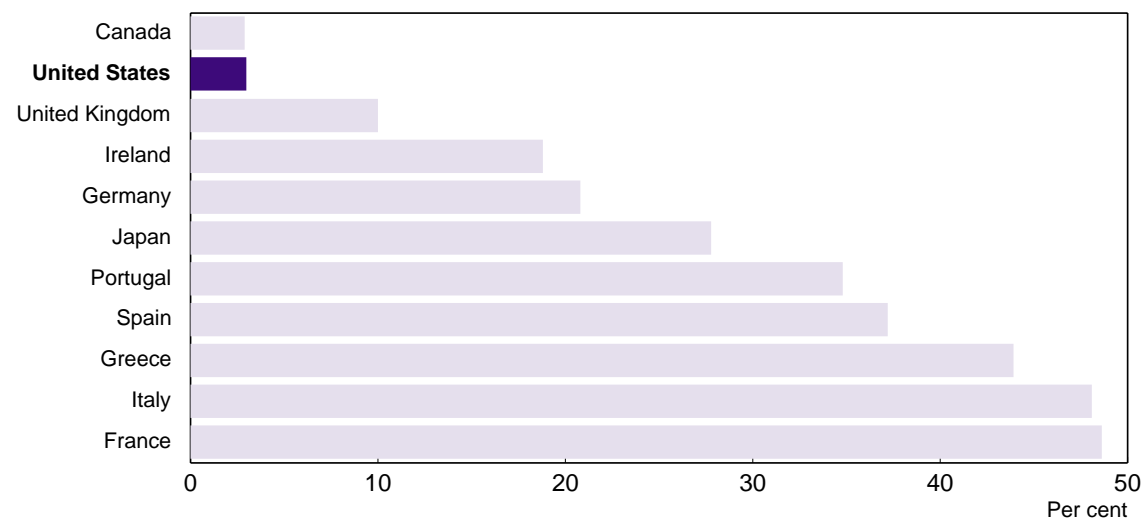

1. The social-insurance tax rate is the sum of the statutory rate paid by both the employee and the employer for top wage-income levels.

Source: OECD and European Tax Handbook, 1999.

\section{Box 2. The federal income tax}

All individuals or married couples are liable for income tax on gross income. This consists of wages and salaries, unemployment compensation, tips and gratuities, interest, dividends, annuities, pensions, rents, royalties, capital gains, alimony, up to 85 per cent of Social Security benefits if the recipient's income exceeds a base amount, and certain other types of income. Among the items excluded from gross income, and thus not subject to tax, are public assistance benefits and interest on exempt securities (mostly state and local government bonds). A number of other exclusions are made from this definition in order to arrive at the concept of adjusted gross income (AGI) that serves as the reference concept from which a number of deductions are made in order to arrive at taxable income. ${ }^{1}$ All tax filers must claim exemptions, depending on their personal circumstances, and can choose between taking a standard deduction or deducting individual items of expenditure for certain diverse uses. The standard deduction and the personal exemption do not favour any particular sources or uses of income over others, nor do they significantly complicate the tax system. In practice, together they create an extra tax bracket at the bottom of the income scale, in which the effective tax rate is zero. ${ }^{2}$ Itemised deductions, on the other hand, favour particular uses of income and make the tax compliance process more complicated and, in practice, lessen the progressivity of the tax system (see below). In 2000, statutory federal income tax rates ranged from 15 to 39.6 per cent. The top federal rate was relatively low by international standards and began only at a high level of income (Table 1), but in making such comparisons, allowance has to be made for state income tax rates. The average highest statutory state income tax was 5.5 per cent in 2000 with peak of 12 per cent in Massachusetts, while the lowest top rate averaged 2.3 per cent in those states with an income tax. However, state and local income taxes are a federal itemised deduction, so that the total federal and state and local marginal rate is not additive for taxpayers who itemise, but rather multiplicative. Overall, the United States had the lowest combined marginal rate for high earners amongst major countries (Figure 5).

1. Among these deductions from gross income are: alimony paid; penalties on early withdrawal of savings; payments to an Individual Retirement Accounts; payments to a Keogh retirement plan; and self-employed health insurance payments and certain moving expenses.

2. For example, in 2000, the tax-exempt threshold amounted to $\$ 18550$ for a married couple with two children (\$2 800 times four plus $\$ 7$ 350). Taking account of the refundable child tax credit and the (refundable) Earned Income Tax Credit, the effective tax-exempt threshold would be $\$ 28683$ for an employee with a child. 
Table 1. Personal income taxation in selected OECD countries 2000

\begin{tabular}{|c|c|c|c|c|c|c|c|c|}
\hline & $\begin{array}{l}\text { United } \\
\text { States }\end{array}$ & Canada & France & Germany & Italy & Japan $^{1}$ & Spain & $\begin{array}{l}\text { United } \\
\text { Kingdom }\end{array}$ \\
\hline \multicolumn{9}{|l|}{ Labour income } \\
\hline \multicolumn{9}{|l|}{ Taxes raised by central government } \\
\hline Range of statutory rates (per cent) & 15-39.6 & $17.51-30.45$ & $10.5-54$ & $0-53.8$ & $18.5-45.5$ & $10-37$ & $15-39.6$ & $20-40$ \\
\hline Number of tax rates ${ }^{2}$ & 5 & 4 & 6 & 4 & 5 & 4 & 6 & 3 \\
\hline Rates of sub-national taxes (per cent) ${ }^{3}$ & $0-12.0$ & $0-18.1$ & - & - & $0.5-1$ & $5-13$ & $3-8.4$ & - \\
\hline $\begin{array}{l}\text { Tax threshold (per cent of APW } \\
\text { income) }\end{array}$ & 0.24 & 0.03 & 0.2 & 0.21 & 0.02 & 0.09 & 0.21 & 0.24 \\
\hline $\begin{array}{l}\text { Highest rate starts at (proportion of } \\
\text { APW income) })^{5}\end{array}$ & 9.7 & 1.8 & 2.2 & 2.1 & 3.5 & 7 & 4.6 & 1.8 \\
\hline \multicolumn{9}{|l|}{ Highest tax rates on capital income } \\
\hline Interest from bank deposits & 46.8 & 48.6 & 25 & 53.8 & 27 & 20 & 48 & 40 \\
\hline Dividends & 46.8 & 48.6 & 61.2 & 53.8 & 12.5 & 50 & 48 & 40 \\
\hline Capital gains & 20 & 48.6 & 26 & 0 & 12.5 & 26 & 20 & 40 \\
\hline
\end{tabular}

1. Tax on dividends depends on the size of distribution. Tax credit is not included

2. Excluding zero band or basic allowance.

3. For the United States, it excludes local income taxation.

4. It includes sub-national tax rates and employee's social security contributions.

5. APW = average production worker in manufacturing, single, no children

Source: OECD Tax Database, 1999. 


\section{Figure 5. Highest combined social insurance and personal income tax rate} 2000

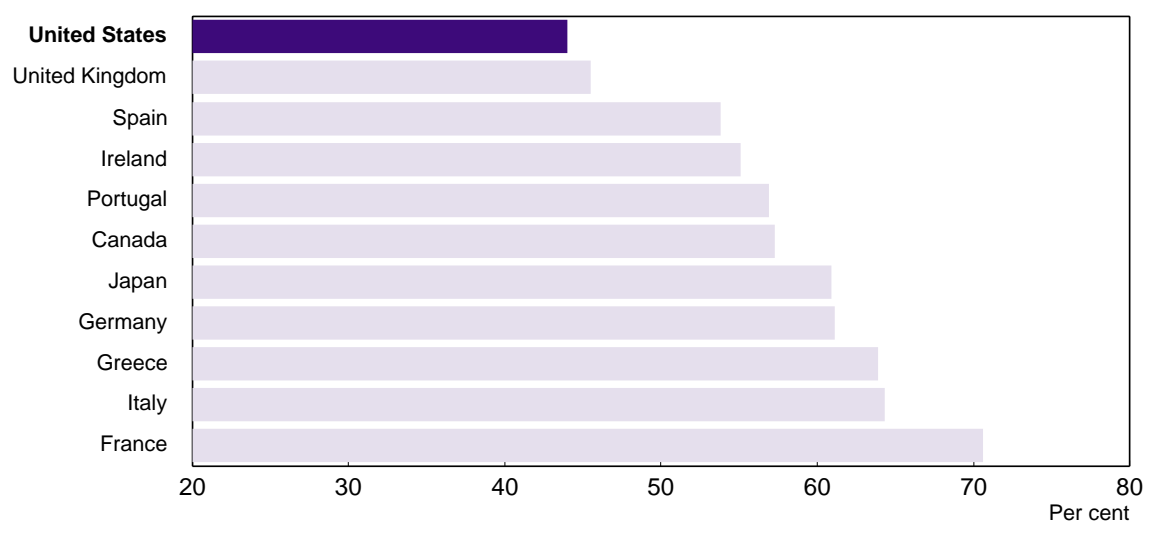

Note: The combined tax rate is calculated as the complement of the ratio of take-home pay to the product of the gross pay and one plus the employers' social security rate.

Source: OECD Tax database.

\section{Areas of excessive complexity}

8. Apart from incentive and equity effects that are considered later, the principal problems with the personal income tax arise from its complexity (Joint Committee on Taxation, 2001b). This report makes a wide-ranging set of proposals aimed at simplifying the federal tax system. In particular, it strongly supports the need to eliminate burdensome, complex computations and the elimination of tax increases introduced by phase-outs. The elimination of a number of phase-outs would provide simplification for up to 30 million filers. Although, the broad lines of the income tax are simple, its implementation has become extremely intricate because of the special treatment for certain types of income or the deduction of certain types of outlays. These tax breaks can take the form of exemptions, deductions or credits, refundable or not. In order to limit the cost of many of these tax allowances, they are limited to lower income groups and are phased out over varying income ranges. Each of these special treatments requires detailed implementation to deal with the varied circumstances of each taxpayer. Even some of the general deductions are phased out at very high income levels. All of these provisions create many effective marginal tax rates. If the system of deductions was not sufficiently complicated, there is also a parallel tax system that has a much higher deduction than the standard system but only two rates and a different definition of income. If the tax due under the second system is higher than the tax under the first system, then the amount calculated under the second system has to be paid. This system, known as the Alternative Minimum Tax (AMT), was designed to reduce the number of higher-income people paying no tax, but in fact it applies increasingly to middle-income taxpayers (see Box 3). Moreover, it has not achieved its original goal of lowering the number of people who pay no tax. Finally, there have been questions raised about the tax treatment of stock options that have been a major source of income for many business executives. 


\section{Box 3. The Alternative Minimum Tax}

The revenue impact of a large number of tax deductions is limited by the impact of the Alternative Minimum Tax (AMT), a very unusual levy. This system for determining tax liability runs in parallel to the standard income system. A number of deductions allowable under standard taxation are added back to taxable income for AMT purposes. A flat deduction is then made against this wider definition of income and the remaining income is taxed in two tranches: the first at a rate of 26 per cent, the second at 28 per cent. If the AMT liability exceeds the standard income tax liability (net of tax credits), then the total tax due is determined by the AMT liability. The AMT deduction is itself phased out at the rate of 25 cents per dollar of AMT income above a certain limit, thereby generating a 32.5 or 35 per cent marginal rate over the income range in which it is phased out. Most of the taxpayers obliged to calculate their AMT liability do not actually have to pay the tax as their liability is less than their regular tax liability. In any case, no other OECD Member country has such a double tax system with the actual liability being determined as the greater of the liabilities under the two systems.

The AMT adds substantially to complexity without achieving its original goals. The AMT was first introduced in 1975 following concern that a number of high-income taxpayers were not paying income tax. However, its original motivation was largely lost when the 1986 Tax Reform Act was passed, as this law ended most of the blatant tax shelters that created artificial losses. In 2000, of the $\$ 41$ billion difference between the total of taxable income and the AMT base only $\$ 7$ billion could be accounted for by activities that remotely resemble tax shelters. In fact, 97 per cent of the difference was accounted for by adding back the deductions for state and local taxes, personal exemptions and aggregate miscellaneous deductions (Rebelein and Tempalski, 2000). ${ }^{1}$ In practice, the AMT has not prevented a further increase in the number of high-income filers apparently paying no income tax. Between 1987 and 1998 , the number of filers with incomes of over $\$ 200000$ (in constant 1976 dollars) who paid no US tax has increased from 126 to 289, while those paying no world-wide tax has increased from 85 to 253 (Balkovic, 2001). The principal reason for the apparent non-taxation is that these filers had large incomes from the interest on tax-exempt bonds. ${ }^{2}$ With the increase in the marginal tax rates for high-income earners introduced in the 1990s, the AMT now mainly affects middle- rather than high-income tax units.

The AMT parameters have not been changed since 1986, pushing up the number of people liable for the tax. The highest AMT rate (28 per cent) was equal to the highest statutory rate of the personal income tax in 1986. However, through most of the 1990s, the highest rate was 39.6 per cent, pulling the tax bill of high earners above a rate calculated on a wider basis but with a lower marginal rate. That is, the high rates introduced in the 1990s removed a large number of people from the AMT net and the lower rates of the next decade will do the reverse. Prior to the introduction of the new tax law, the number of people liable was projected to rise even faster in the next ten years than in the past decade, raising the predicted take of the tax to 0.25 per cent of GDP by 2010 , up from 0.06 per cent of GDP in 2000. The new law increases the yield of the AMT to 0.6 per cent of GDP by 2010, thereby offsetting some of its gross cost.

1. Miscellaneous deductions generally are expenses related to the production of income. They can be claimed only if their total exceeds 2 per cent of taxable income. Expenses below 2 per cent cannot be deducted. There are a few adjustments that slightly reduce the AMT base.

2. The other reasons for the income being untaxed are the deductions allowed for medical expenses and for uninsured losses through theft.

\section{Tax expenditures}

9. Most nations' tax codes contain differing treatment for certain types of income or treat certain types of outlays as deductions from income. The United States is no exception to this general rule. Congress has instructed the Administration to monitor the use of such exemptions and deductions since 1974. Each year the budget presented to Congress by the Administration must contain estimates of the cost of all such special treatments, calculated both according to the revenue loss relative to an income tax base 
(using the Haig-Simon or Hicksian definition of comprehensive income) and the cost of replacing such outlays by government expenditure. Measuring the deviations of the current income tax system from a baseline does not imply that the baseline system itself is desirable but attempts to quantify the cost of deviations from the baseline system. Indeed, the list of tax expenditure items, as well as their costs, would look completely different, if the calculation were start from a consumption tax base. In any case, the measurement of tax expenditures is difficult and requires knowledge of the individual circumstances of each taxpayer. Moreover, their cost is evaluated on the basis that each is abolished while all others remain in place. However, if all items were abolished, the marginal tax rates facing individuals would be changed and so the cost of the tax expenditure would also change. Consequently, the overall cost of the expenditures cannot be judged from the sum of the components. Nonetheless, such a sum does give an order of the magnitude of the implicit outlays. By 2000, their cost had reached 7.8 per cent of GDP up from 6.3 per cent in 1988 (Table 2). Such a figure can be contrasted to total federal spending of 16.8 per cent of GDP and a yield of federal individual and corporate income taxes of 12.6 per cent of GDP. Allowances against the individual income tax represent 90 per cent of total tax expenditures.

Table 2. The evolution of tax expenditures between 1988 and 2000 Per cent of GDP

\begin{tabular}{|c|c|c|c|c|c|}
\hline & \multirow[b]{2}{*}{2000} & \multirow[b]{2}{*}{1988} & \multicolumn{2}{|c|}{$\begin{array}{l}\text { Impact of changes } \\
\text { introduced in } 1986\end{array}$} & \multirow{2}{*}{$\begin{array}{c}1988 \\
\text { based on } \\
1986 \\
\text { tax systems }\end{array}$} \\
\hline & & & $\begin{array}{c}\text { Programmes } \\
\text { abolished or } \\
\text { curtailed }\end{array}$ & $\begin{array}{c}\text { Impact of } \\
\text { reduced } \\
\text { marginal } \\
\text { tax rates on } \\
\text { programme }\end{array}$ & \\
\hline Programmes that have existed since 1988 & 6.67 & 6.07 & -0.14 & -2.06 & 8.25 \\
\hline New programmes & 0.58 & 0.00 & 0.00 & 0.00 & 0.00 \\
\hline Programmes abolished in 1986 but re-introduced & 0.56 & 0.00 & -0.57 & 0.00 & 0.57 \\
\hline Programmes abolished between 1988 and 2000 & 0.00 & 0.24 & -0.80 & -0.05 & 1.10 \\
\hline Programmes abolished in 1986 & 0.00 & 0.00 & -0.22 & 0.00 & 0.22 \\
\hline All programmes & 7.81 & 6.31 & -1.74 & -2.11 & 10.14 \\
\hline
\end{tabular}

Note: Tax expenditures were estimated for 1988 using the 1986 tax system as 1988 was the first year when the 1986 changes were fully in force. The cost estimates calculate the reduction due to the change in the deduction and then that resulting from lowering of the marginal tax rate. The decomposition of the total reduction would be different if the order of calculation were reversed.

Source: Office of Management and Budget; Office Tax Analysis, Department of Treasury.

10. There are a large number of different tax expenditure items, but revenue losses are very concentrated in a way that serves to move the personal income tax base towards a consumption base, a shift that fits with the main thrust of this chapter. The disaggregated tax expenditure data illustrate the extent to which policy has been oriented in this direction. In total, the budget identifies 129 items that cost more than $\$ 10$ million annually. However, just ten account for over three-quarters of the total (Table 3). It is noticeable that those aimed at reducing the rate of taxation on capital income figure prominently amongst the largest tax expenditures. Principal amongst these were lower tax rates on capital gains than on other income, the exemption of capital income from retirement saving during the period when saving is building-up and the tax treatment of the income of life insurance companies. Housing also figures prominently, mainly through mortgage-interest deductions. There is also a deduction for the payment of real-estate taxes. Indeed, overall, housing accounts for 14 per cent of total individual tax breaks. Tax 
expenditures promoting other social goals, favouring families with children, subsidising education, health and training costs account for a further 25 per cent of the total. As education represents an investment that produces a taxed return, there is a logic to making such activities deductible. The biggest category of tax expenditures concerns special deductions for saving, accounting for 39 per cent of the total. Finally, there are various deductions that serve to reduce the impact of state taxation on income and consumer durables, even though the implicit income from the latter is not taxed, or favour borrowing by states and local authorities. A number of tax expenditures (Earned Income Tax Credit and Social Security) favour lower-income households, but of those analysed here, the biggest are of greatest benefit to households with incomes between $\$ 75000$ and $\$ 200000$ (Table 4).

Table 3. The biggest and most rapidly growing tax expenditures

\begin{tabular}{|c|c|c|c|}
\hline & \multicolumn{2}{|c|}{2000} & \multirow{2}{*}{$\begin{array}{l}\text { Change between } \\
2000-1998 \\
\text { Per cent of GDP }\end{array}$} \\
\hline & \$ million & Per cent of GDP & \\
\hline \multicolumn{4}{|l|}{ Biggest expenditures } \\
\hline Capital gains (lower tax rate, treatment at death and housing) & 113320 & 1.15 & 0.14 \\
\hline Employer pension plans & 104170 & 1.06 & -0.03 \\
\hline Exclusion of employer health plan premia & 98640 & 1.00 & 0.39 \\
\hline Deductibility of state and local taxes & 68660 & 0.70 & 0.05 \\
\hline Deductibility of mortgage interest & 60270 & 0.61 & 0.11 \\
\hline Exclusion of interest on public purpose bonds & 32830 & 0.47 & 0.04 \\
\hline Accelerated depreciation of machinery & 30660 & 0.31 & -0.18 \\
\hline Child credits & 25707 & 0.28 & n.a. \\
\hline Deduction of other charitable gifts & 27070 & 0.26 & 0.08 \\
\hline \multirow[t]{3}{*}{ Individual Retirement Accounts } & 20310 & 0.21 & -0.02 \\
\hline & 2000 & 1988 & $\begin{array}{l}\text { Annual average } \\
\text { growth rate }\end{array}$ \\
\hline & \multicolumn{2}{|c|}{ \$ million } & Per cent \\
\hline \multicolumn{4}{|l|}{ Most rapidly growing tax expenditures } \\
\hline Tax credit for orphan drug research & 100 & 1 & 46.8 \\
\hline Alternative fuel production credit & 1310 & 15 & 45.1 \\
\hline Deferral for foreign controlled corporations & 6200 & 150 & 36.4 \\
\hline Accelerated depreciation on rental housing & 4740 & 310 & 25.5 \\
\hline Exemption of credit unions & 2310 & 175 & 24.0 \\
\hline Exclusion of employer provided child care & 890 & 80 & 22.2 \\
\hline Accelerated depreciation of buildings (other than housing) & 3620 & 350 & 21.5 \\
\hline Credit for low income housing & 4350 & 425 & 21.4 \\
\hline New technology credit & 50 & 5 & 21.2 \\
\hline Exclusion of foreign sales corporations & 5990 & 780 & 18.5 \\
\hline Capital gains on housing & 23170 & 4605 & 14.4 \\
\hline Keogh plans & 6980 & 1475 & 13.8 \\
\hline Exemptions for small passive losses & 4720 & 1205 & 12.1 \\
\hline Exclusion of interest on public purpose bonds & 32830 & 9975 & 10.4 \\
\hline Exclusion of employer health plan premia & 98640 & 31005 & 10.1 \\
\hline
\end{tabular}

Source: Office of Management and Budget. 
Table 4. The distribution of revenue loss for selected tax expenditures by income category Estimates made using 2000 tax rates and 2000 income levels

\begin{tabular}{|c|c|c|c|c|c|c|c|}
\hline & $\begin{array}{l}\text { Real } \\
\text { estate } \\
\text { tax }\end{array}$ & $\begin{array}{c}\text { State } \\
\text { and } \\
\text { local taxes }\end{array}$ & $\begin{array}{l}\text { Charitable } \\
\text { contributions }\end{array}$ & $\begin{array}{l}\text { Mortgage } \\
\text { interest }\end{array}$ & $\begin{array}{c}\text { Four } \\
\text { selected tax } \\
\text { expenditures }\end{array}$ & $\begin{array}{l}\text { Cumulative } \\
\text { share of } \\
\text { total tax } \\
\text { reduction }\end{array}$ & $\begin{array}{c}\text { Tax savings } \\
\text { relative to } \\
\text { tax paid }\end{array}$ \\
\hline & \multicolumn{7}{|c|}{ Per cent } \\
\hline \multicolumn{8}{|l|}{$\begin{array}{l}\text { Income category } \\
\text { ( } \$ 000 \text { per year) }\end{array}$} \\
\hline $0-10$ & 0.0 & 0.0 & 0.0 & 0.0 & 0.0 & 0.0 & n.a. \\
\hline $20-30$ & 0.2 & 0.0 & 0.4 & 0.2 & 0.2 & 0.2 & n.a. \\
\hline $20-30$ & 0.8 & 0.2 & 1.1 & 0.6 & 0.6 & 0.8 & 9.4 \\
\hline $30-40$ & 2.1 & 0.7 & 2.1 & 2.0 & 1.7 & 2.5 & 8.3 \\
\hline $40-50$ & 4.0 & 1.8 & 3.5 & 4.3 & 3.4 & 5.9 & 13.2 \\
\hline $50-75$ & 13.3 & 7.4 & 12.0 & 13.5 & 11.6 & 17.5 & 15.0 \\
\hline $75-100$ & 18.9 & 12.7 & 13.8 & 20.5 & 17.0 & 34.4 & 22.2 \\
\hline $100-200$ & 34.5 & 27.7 & 21.3 & 36.5 & 31.0 & 65.4 & 21.5 \\
\hline \multirow[t]{2}{*}{$200+$} & 26.2 & 49.6 & 45.8 & 22.5 & 34.6 & 100.0 & 13.6 \\
\hline & \multicolumn{6}{|c|}{$\$$ billion } & Per cent \\
\hline All income categories & & & & & & & \\
\hline Total tax saving & 20.2 & 38.7 & 28.4 & 60.6 & 148.0 & - & 16.7 \\
\hline
\end{tabular}

Source: Joint Committee on Taxation (2001a).

11. Widening the base of taxation by curtailing tax expenditures and so being able to lower marginal tax rates has not been a major issue since 1986. If anything, much of the move towards a comprehensive income tax with a Haig-Simon definition that occurred in the 1986 reform has been reversed in subsequent years. In 1988, when the reform programme had been fully implemented, it had reduced expenditures by 1.7 percentage points of GDP. Since then, tax expenditures have rebounded by 1.5 percentage points of GDP, though part of this move reflects an increase in marginal tax rates in the 1990s. Several of the items that were abolished or reduced in 1986 have subsequently been re-introduced, moving back towards a consumption base. This oscillation is not new and has recurred several times in past decades (Edwards, 2001). For instance, capital gains are once again taxed at a lower rate than the standard income tax rate and several new tax-deferred savings instruments have been introduced. In addition, over 50 new tax expenditures have been introduced, mainly in the social area.

\section{Phase-outs, effective and statutory marginal tax rates}

12. Phase-outs are means of limiting the benefit of a tax expenditure to certain income groups, and their use has been growing. They were markedly expanded by the Tax Reform Act of 1986 to help pay for the reduction overall marginal tax rates. ${ }^{3}$ This instrument reduces the value of a tax deduction as income increases. The first to be introduced was the phase-out of deductible contributions to Individual Retirement Accounts for those with an AGI above a high threshold. In subsequent years, phase-outs were applied to a wider set of tax breaks. By 2000, there over 20 different phase-outs and fully 25 per cent of individual taxpayers were in effective marginal income tax brackets above the statutory rate implied by their income (Table 5). The phase-outs sometimes imply high additional marginal tax rates (notably the HOPE

3. Prior to 1986, the major phase-outs applied only to the Earned Income Tax Credit and to the reduction on the credit rate for the Child and Dependant Care Tax. 
education credit), but the addition to the statutory rate is generally small. They do, however, overlap. In a given income range, a taxpayer could have up to five phase-outs applied in calculating the appropriate tax liability (Figure 6). Such a system can generate theoretically up to 120 different marginal tax rates at the same income level, depending on the combination of allowances for which the taxpayer is eligible.

Table 5. Statutory tax rates and marginal effective tax rates

\begin{tabular}{ccccc}
\hline $\begin{array}{c}\text { Statutory tax rate } \\
\text { for a taxpayer }\end{array}$ & $\begin{array}{c}\text { Average effective } \\
\text { marginal tax rate }\end{array}$ & $\begin{array}{c}\text { Impact of phase-outs } \\
\text { on marginal tax rates } \\
\text { of those affected }\end{array}$ & $\begin{array}{c}\text { Proportion of tax } \\
\text { payers affected }\end{array}$ & $\begin{array}{c}\text { Total number of } \\
\text { taxpayers with } \\
\text { effective rates above } \\
\text { statutory rates }\end{array}$ \\
\hline Per cent & Per cent & Percentage Points & Per cent & Millions \\
\hline & & & & \\
0.0 & -2.0 & -11.2 & 17.5 & 40.5 \\
28.0 & 16.8 & 7.4 & 24.9 & 62.2 \\
31.0 & 28.4 & 1.4 & 25.9 & 26.6 \\
36.0 & 31.7 & 1.0 & 66.7 & 3.0 \\
39.6 & 37.1 & 1.2 & 90.9 & 1.1 \\
\hline
\end{tabular}

Source: Joint Committee on Taxation (2000a).

Figure 6. Number of phase-outs and phase-ins by income range ${ }^{1}$

For a married couple; 2000

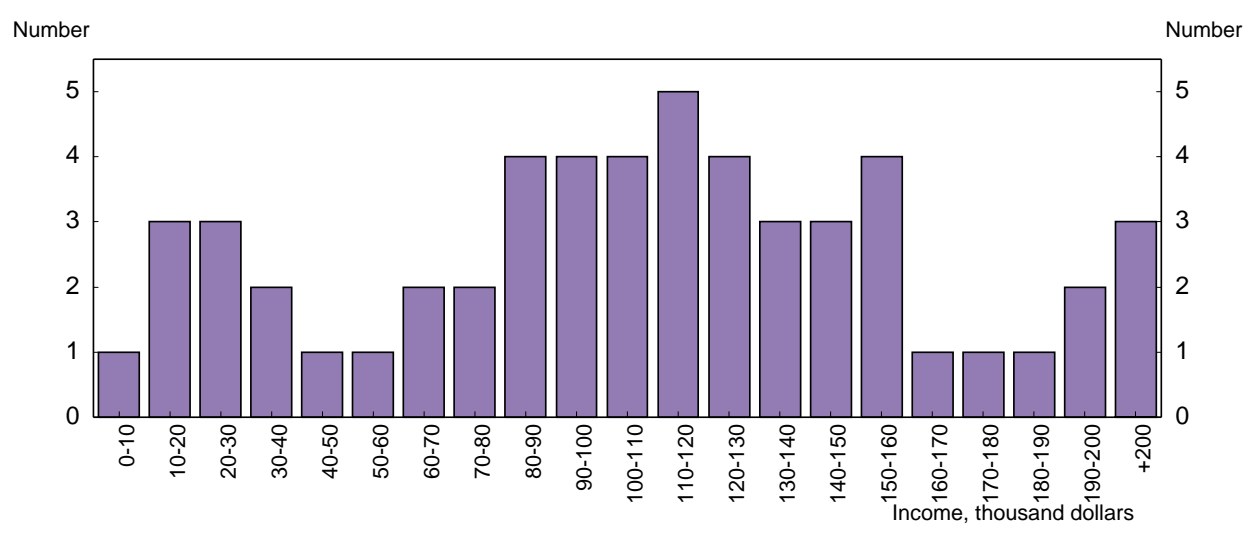

1. However, a family can claim the HOPE scholarship credit and Lifetime Learning Credit for several child. Each credit can be phased-out over the same income range with the result that the number of phase-outs could be much higher than presented in the figure.

Source: Joint Committee on Taxation (2001b).

\section{Employee stock options}

13. The treatment of stock options under the personal income tax system is anomalous relative to the treatment of other wage income and the treatment under corporate tax and financial reports. For most stock options, the difference between the price of the underlying share and the strike price (generally the price of 
the share when the option was issued) is typically taxed as employment income when it is exercised. ${ }^{4}$ This difference can be included as a business expense and so reduces the taxable profit of a company. ${ }^{5}$ However, companies do not have to treat the profit that employees make on the sale of an option as a cost in their financial reports. Options have a value when granted, and it is this value that should be taxed as it is effective addition to wage income that an employee receives, with the gain from holding the option being taxed at the capital gains rate. Such an approach would need a valuation for the option. However, standard pricing formulae for options are based on the volatility of the underlying share and assume that an investor is able to hedge his position and close it out at any point of time. Neither of these assumptions hold for executive option plans. Executives are not expected to hedge their positions and cannot sell before the vesting that is usually a relatively long period. Both of these factors lead standard formulae to overstate substantially the value of an option issued under a corporate incentive plan (Hall and Murphy, 2000). Once these factors are corrected using a new formula, the recent increase in estimated total Chief Executive Office (CEO) pay substantially moderated, suggesting some over-taxation of the gains on stock options (Figure 7). One reason for the existence of stock options is that tax legislation does not allow executive compensation of over $\$ 1$ million per year to be treated as a business cost, unless a significant portion is performance related. Options are automatically considered to be performance-related pay and so are not subject to the million dollar cap.

\section{Figure 7. CEO pay and risk-adjusted pay for major US companies}

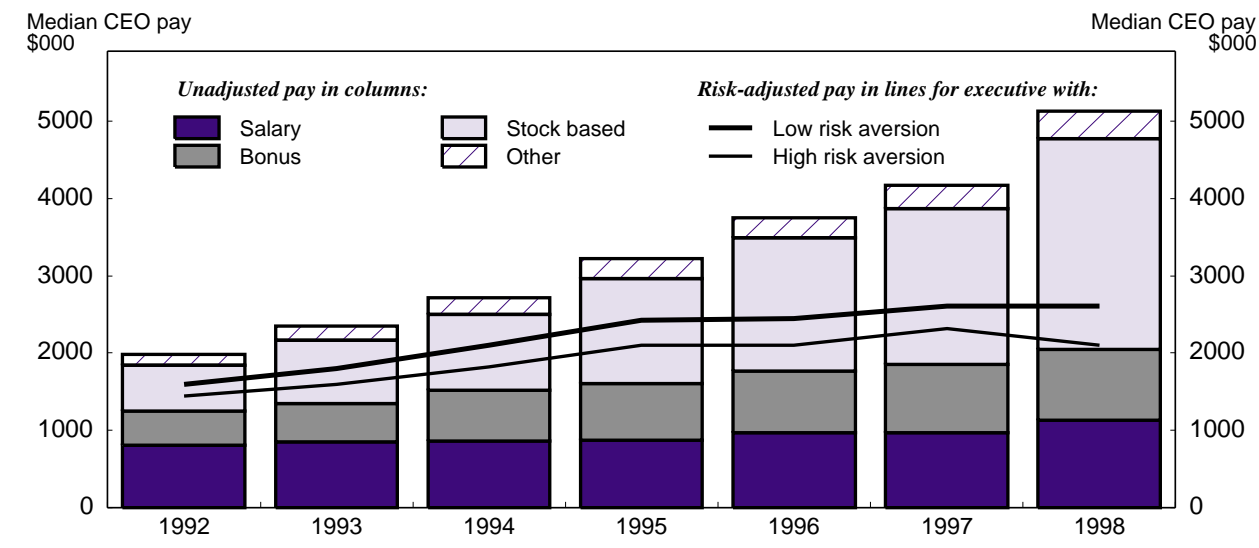

Note: Median pay levels (in constant 1998 dollars) based on ExecuComp data for S\&P 500 CEOs (financial firms and utilities excluded). Total compensation (in columns) defined as the sum of salaries, bonuses, benefits, stocks options (valued on date of grant using the Black-Scholes formula), stock grants and other compensation. Executive values are estimated using the "certainty equivalence" approach.

Source: (c) Hall and Murphy (2000).

4. In principle, if an option has a readily ascertainable market value it can be taxed. However, employee stock options have a number of features that mean that they do not correspond to market-traded options. For instance, they have a vesting period before they become the property of the individual, and they typically run for much longer period than traded options. Valuations based on option theory have not been accepted by the IRS for tax purposes. Consequently, nearly all non-qualified options are taxed on realisation.

5. The main type of stock option referred to in this paragraph is a non-qualified stock option (NQSO) which are typically taxed at exercise, with subsequent holding gains taxed as capital gains. Incentive stock options are not subject to income tax ever. However, when the resulting shares are finally sold, the entire realisation amount is taxed. There is an annual cap of $\$ 100000$ for an individual and are not ever deductible from the corporate income tax base. Only five per cent of total options are granted in this form. 


\section{The consequences of the taxation of employment income}

14. The response of households to tax rates is a crucial element in evaluating the efficiency of a tax system. Taxation gives rise to unnecessarily high deadweight costs to the economy, if the product of marginal tax rates and the response of employment to changes in the tax rate is significant. Beyond the impact of taxation on hours worked, significant efficiency costs can arise along other dimensions of effort such as investment in human capital, intensity of work and risk-taking. In addition, costs are raised by shifts towards tax-favoured activities. As a result of these movements, efficiency effects are best judged by the elasticity of taxable income with respect to the tax rate, a figure that appears to be higher than the elasticity of hours worked. Some microeconomic estimates suggest that the average deadweight cost of overall income taxation could be quite high but such calculations are sensitive to underlying assumptions. Moreover, these effects have to be set against equity considerations in determining the quality of any given tax structure.

\section{Labour supply}

15. Distortions are introduced to the labour market by income taxation. Most research has found that taxes have relatively small effects on labour supply both in terms of hours worked and the labour-force participation rate. Male labour supply appears to be particularly unresponsive to changes in the real after-tax wage, with an elasticity of only 0.1 . In contrast, the female labour-force is more responsive, with an elasticity of $0.5 .^{6}$ Overall, hours worked appear to have an elasticity of about 0.25 with respect to the after-tax price of labour (Triest, 1996). Whether the elasticity varies with income is in dispute, with some studies finding that low-qualified workers have a more elastic labour supply but others finding the reverse. As the United States is a low-tax country, the average marginal tax wedges on labour income are somewhat below the OECD average for most wage and family situations (Figure 8 and Table 6). The wedge in the United States would be even more below the OECD average if consumption taxes, which are particularly low, were included in the calculations. ${ }^{7}$

\section{Marriage and the income tax}

16. A progressive income tax system faces a conflict when deciding how to tax a married couple. On one hand, horizontal equity might suggest that couples with similar combined incomes should pay the same amount of tax, regardless of which partner earns the income. On the other hand, there is also a desire to ensure that a married couple does not face higher taxation than an unmarried couple with the same income. These are conflicting goals when rates are progressive. It is impossible to have a progressive rate structure and not change the tax burden when two earners marry without having income splitting. But income splitting means that a married couple, where only one person works, will pay less tax than a single person with the same income, especially at higher levels. Over the longer run US tax policy has oscillated in its objectives. As this shifting policy response indicates, the horizontal equity objective, neutrality with

6. The results assume sequential decisions on when partners work. Models that allow joint determination have lower elasticities (Hoynes, 1996).

7. A striking feature of the interaction between taxes and benefits is that unemployed workers with a non-employed spouse face high marginal tax rates on additional income. Assuming that the unemployed principal earner accepts a full-time job, the marginal tax rate is 68 per cent. Taking a part-time job is even more costly, with the tax wedge being over 100 per cent. 
respect to marriage and a progressive tax system have to be weighed carefully. Advancing on any one of these objectives necessarily requires making a sacrifice with respect to one or both of the other two. ${ }^{8}$

Figure 8. Marginal tax wedges by family type and wage level ${ }^{1}$ 2000
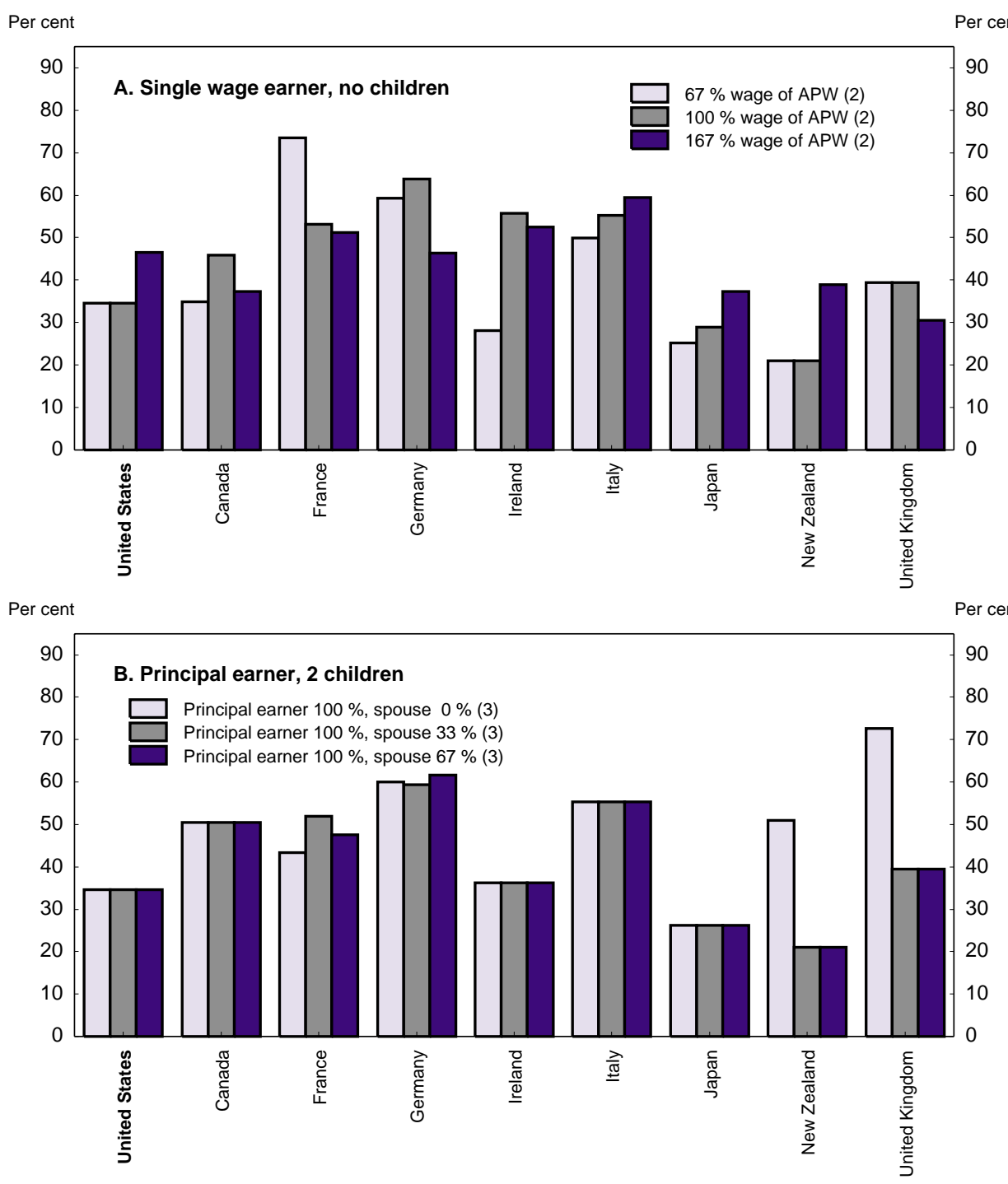

1. Marginal tax rates covering employee's and employer's social security contributions and personal income tax with respect to a change in gross labour costs.

2. APW: Average production worker in manufacturing.

3. Refers to proportion of wage of APW.

Source: OECD, Taxing wages.

8. The interaction of these factors means that couples with one earner receive marriage bonuses, while 61 per cent of couples with $\$ 100000$ paid more tax than if they were single, nearing to 78 per cent if both were working. Overall, bonuses and penalties were about the same (Bull et al., 1999). The penalty could also affect incentives to enter marriage (Rosebaum, 2000; and Eissa and Hoynes, 1999). 
ECO/WKP(2001)39

Table 6. Marginal effective tax rates for different family types ${ }^{1}$ 1997

\begin{tabular}{|c|c|c|c|c|c|c|}
\hline \multirow{4}{*}{$\begin{array}{l}\text { Principal earner } \\
\text { Secondary earner }\end{array}$} & \multirow{2}{*}{\multicolumn{2}{|c|}{ Full-time employed }} & \multirow{2}{*}{\multicolumn{2}{|c|}{ Unemployed }} & \multicolumn{2}{|c|}{$\begin{array}{c}\text { Moving from } \\
\text { unemployment to: }\end{array}$} \\
\hline & & & & & $\begin{array}{l}\text { Full-time } \\
\text { employed }\end{array}$ & $\begin{array}{l}\text { Part-time } \\
\text { employed }\end{array}$ \\
\hline & \multicolumn{2}{|c|}{$\begin{array}{c}\text { Moving from } \\
\text { non-employment to: }\end{array}$} & \multicolumn{2}{|c|}{$\begin{array}{c}\text { Moving from } \\
\text { non-employment to: }\end{array}$} & \multirow{2}{*}{\multicolumn{2}{|c|}{ Non-employed }} \\
\hline & $\begin{array}{l}\text { Full-time } \\
\text { employed }\end{array}$ & $\begin{array}{l}\text { Part-time } \\
\text { employed }\end{array}$ & $\begin{array}{l}\text { Full-time } \\
\text { employed }\end{array}$ & $\begin{array}{l}\text { Part-time employed } \\
\text { without benefit } \\
\text { entitlements }\end{array}$ & & \\
\hline United States & 19 & 11 & 20 & $\mathbf{0}$ & 68 & 102 \\
\hline Japan & 12 & 10 & 10 & 7 & 60 & 133 \\
\hline Germany & 51 & 50 & 31 & 19 & 80 & 115 \\
\hline France & 28 & 38 & 29 & 30 & 76 & 69 \\
\hline Germany & 51 & 50 & 31 & 19 & 80 & 115 \\
\hline Italy & 33 & 25 & 37 & 19 & 63 & 84 \\
\hline United Kingdom & 28 & 20 & 60 & 55 & 72 & 93 \\
\hline Canada & 37 & 33 & 34 & 29 & 75 & 105 \\
\hline United Kingdom & 28 & 20 & 60 & 55 & 72 & 93 \\
\hline EU average & 35 & 31 & 38 & 38 & n.a. & 107 \\
\hline OECD average & 32 & 27 & 34 & 32 & n.a. & 107 \\
\hline
\end{tabular}

1. Marginal effective tax rate $=1$ - (net income in work - net income out of work)/change in gross income. Countries are ranked according to rate for a part-time employed principal earner with a non-employed secondary earner. Part-time employment corresponds to 16 hours or two days each week, and total earnings are 40 per cent of the average production worker level of earnings. Earnings from full-time employment correspond to average production worker earnings.

Source: OECD (1999), Benefit Systems and Work Incentives.

17. The labour supply response of some spouses suggests that there might be a significant deadweight cost from policies that result in a high marginal tax rate for the spouse that is most likely to vary labour supply. If the decisions to participate in the labour force are made by a couple, then the second person to work in a couple does face a higher marginal tax rate, as their Social Security contributions bring limited additional benefits, because of regulations that provide benefits to a spouse who does not have earnings. In addition, the marginal tax rate on the first dollar of the second earner can be thought of as the marginal rate on the last dollar of the first earner. Overall, these factors suggest that spouses typically face a marginal tax rate of 32.1 per cent on the first dollar earned on entry into employment. ${ }^{9}$ A significant proportion of taxpayers face higher marginal tax-rates.

9. The calculation can be illustrated by the following formula. Suppose that gross employee compensation increases by one dollar and that the marginal tax rates are as follows:

- the employer and employee each pay a Social Security and hospital insurance tax of $r$ on the employee compensation excluding the employers Social Security tax payment and hospital insurance tax;

- the rate of state income tax is $s$ on employee compensation excluding the employers Social Security tax payment;

- the rate of federal income tax is $f$ on employee compensation excluding the employers Social Security tax and state income tax payments.

Then the marginal tax payments are as follows:

- Social Security and hospital taxes $\quad 2 r /(1+r)$

- State income tax $\quad s /(1+r)$ 
18. A number of ways exist to reduce the tax burden on married couples. They could be allowed to file as separate units or their social security benefits made to be linked more clearly to their contributions. A further option would be to tax the second earner using a separate flat tax rate, and finally the pre-1986 special deduction for a second earner could be re-introduced. This latter deduction functioned by lowering the tax rate for spouses by 10 per cent up to a certain income ceiling. ${ }^{10}$ One simulation suggests that this latter deduction might be cost-effective, reducing the deadweight cost of this type of taxation by 70 cents for each dollar of revenue lost (Feldstein and Feenberg, 1995). The second-earner deduction may be particularly effective because it is well targeted on reducing the marriage penalty. Of the total cost of a second-earner deduction almost 80 per cent would go to reducing marriage penalties (Bull et al., 1999). It is this option that the President proposed to Congress in his tax reduction plan, but the Congress decided on a different version that sets the personal exemptions and rate thresholds for a married couple at twice those of a single person.

\section{The Earned Income Tax Credit}

19. The earned income tax credit (EITC) has successfully increased the employment of low-income people. Below a given income level, the EITC is increased by up to 40 per cent of each additional dollar that is earned; above this ceiling the credit is held constant, and then it is phased out. Thus, there is an incentive to be employed with an income up to the threshold level and a disincentive to earn more than the ceiling once employed. Single workers are able to claim the credit, but the amount is smaller than for families, with the credit being set at the same rate as the employees' Social Security contribution. Though the evidence is now somewhat dated, it appears that the EITC reaches a large percentage of its intended beneficiaries. In addition, a number of states have introduced a state EITC, so adding to the incentive to work. In particular, the rapid expansion of the credit in the 1990s has ensured that the tax bill for a working single mother with a low income has declined markedly and, by 1996 had become negative (Meyer and Rosenbaum, 2000). ${ }^{11}$ The proportion of working single mothers employed rose substantially more quickly than for either single women with no children or married women. Amongst unmarried female high-school drop-outs, those with children experienced greater employment gains than those without children despite both groups having low initial employment rates, suggesting that the business cycle was not the main factor in this increase in employment.

20. It might be possible to expand and change the current structure of the EITC in a way that raises labour force participation even more than the present system. In 2001, for a family with two children, the phase-in range ends at an income of $\$ 10000$, somewhat below the yearly minimum-wage income yielded by a full-time job (\$10 712) and it does not distinguish between those who work full time at low-wage job and those who work less than full time at a better rate of pay. The phase-out of the credit starts at an earnings level of $\$ 13090$ for families with at least one child (2001 figures), which is lower than the poverty threshold for a family of three. Sawhill and Thomas (2000) estimate that about 1 million new

- Federal income tax

The overall marginal tax rate is given by $f(1-s) /(1+r)$, provided the taxpayer itemises.

$(2 r+s+f(1-s)) /(1+r)$

With the following values $r=0.0765, s=0.05$ and $f=0.15$, the overall marginal tax rate is 32.1 per cent.

10. The deduction amounted to 10 per cent of earnings subject to tax, effectively reducing the marginal tax rate to 90 per cent of its normal value, as long as the cap was not exceeded.

11. In 1999, the EITC claimed amounted to $\$ 31.9$ billion, up from $\$ 3.9$ billion in 1979 (in 1999 dollars). No other Federal anti-poverty programme has grown at a comparable rate. 
workers would enter the labour force if the phase-in range was extended to an earnings level corresponding with a full-time minimum wage salary for all family types, even if phase-out rates were increased. ${ }^{12}$

21. The increase in employment of lower income people brought about by the EITC has to be balanced against the cost of funding the benefit. The EITC draws people into work and thus reduces outlays on welfare programmes. Offsets to these gains occur for two reasons. First, the transfers given by the EITC are not lump-sums; rather they are means-tested. Consequently, they change the incentives for the low paid who were already working, making them less likely to work more hours or change job for better pay. Secondly, financing the transfer through the tax system imposes a deadweight cost. Moreover, part of the benefit of the EITC may be shared with employers so changing the relative price of labour to the detriment of people with higher incomes. Whether overall utility improves depends on the weight that that is given to the utility of low-income people versus that of high-income people. Simulations based on plausible labour supply elasticities and welfare functions suggest that if this relative weight is less that two, then the programme should be contracted, and if it is greater than three, then it should be expanded (Liebman, 2001). These simulations are based on perfect substitutability between high and low skill labour-trade extent that may not be the case as employers might still prefer high-income workers. On balance, such simulations suggest that the EITC might be worthwhile for society if the utility of poor people is valued highly. ${ }^{13}$ The simulations are only illustrative but nonetheless highlight that there may be losses that have to be set against the gains from increased participation of lower income workers.

22. People making claims to which they are not entitled appears to be the single most important threat to the political viability of the EITC programme (Hotz and Scholz, 2000). In the 1997 tax year, $\$ 7.8$ billion in EITC claims - or 25.6 per cent of total EITC claims - were erroneously paid to taxpayers. EITC errors are generally associated with family status issues. Many EITC errors are caused by taxpayers claiming children who do not meet the eligibility criteria, especially the residency requirements. The loss through non-compliance has to be offset against the much lower direct administrative costs of the tax-based system compared to standard welfare programmes ${ }^{14}$ whose costs amount to as much as 19 per cent in the case of food stamps, for example, the recent changes in definitions in the EITC programme should help reduce the number of erroneous claims and thereby help increase support for the programme.

\section{The sensitivity of tax yields to tax rates}

23. The response of taxable income to tax rates appears to be greater than the impact of taxation on labour supply alone. Taxable income can move independently of labour supply both because effort can be expended along paths in dimensions other than hours worked such as effort and the choice of conditions of work and also because changes in tax rates alter the cost of undertaking a number of tax-deductible activities. The estimates of the response of tax yields to changes in the tax rate vary considerably (Table 7). Some studies have been based on specific episodes when marginal rates were reduced substantially at the beginning of 1980s and again in 1986. Others have been based on changes in tax yields measured over a period of a few years when individuals had prior knowledge that a tax change was coming and so could alter the timing of their income. One recent study (Gruber and Saez, 2000), exploits a much larger database

12. In 1997, for example, roughly 23.3 per cent of EITC claimants are in the phase-in range of the credit and they receive 22.3 per cent of total payments. Roughly 18.2 per cent are in the flat range and they receive 26.4 per cent of total payments. The remaining 58.3 per cent of claimants are in the phase-out range of the credit and receive 51.3 per cent of total payments (Hotz and Scholz, 2001).

13. A similar point is made by Bassanini et al. (1999).

14. For instance, in FY 1998, the food stamp programme cost $\$ 4$ billion to administer. The programme provides benefits to 8 million households each month. On the other hand, the entire cost of the IRS was only $\$ 7.6$ billion. 
and estimates and estimates that the taxable income elasticity for all households with respect to the price of taxable income (i.e. one minus the federal and state income tax rate) is around 0.4 and that it increases across income groups to 0.57 above $\$ 75000$ (1992 prices). Moreover, if the researchers had not excluded all those with incomes above $\$ 1000000$, then the elasticity for high-income earners would have risen to 1.42 , suggesting that the fall in tax yields from rate cuts would be significantly offset by changed behaviour and perhaps most markedly at high income levels. Such responses are a function of the existing tax system. The itemisation of certain expenses allows a large number of deductions from income and thereby increases the elasticity of taxable income with respect to the tax price. It is possible that part of this elasticity reflects switching into and out of tax-favoured sources of income, rather than an impact on the production of income.

\section{Distributional effects of personal income taxation}

24. The personal income tax system, which has been designed to be progressive, has a small redistribution impact on some measures it has narrowed since 1993 pre-tax income distribution. The shares of pre-tax income - measured with the "Retrospective Income Concept" have fallen, while the share of the top quintile, and especially of the top 1 per cent, has risen, with a peak towards the end of the period (Figure 9). Over the last two decades, the burden of taxes has also shifted to the highest quintile. ${ }^{16}$ The average tax rate of this group has increased, on balance since 1979, though the extent of the increase has been moderated by the lowering of the standard rate of tax on capital gains. Despite the increase in the average tax rate of the top income groups, the United States has one of the widest distributions of post-tax income amongst OECD countries (Figure 10). ${ }^{17}$ Such a distribution does not take into account the transfer payments. Once transfer payments are taken into account, the distribution of income becomes somewhat less unequal (Table 8). The ratio of the income of people in 90-95 ${ }^{\text {th }}$ percentile and those in $5-10^{\text {th }}$ percentile falls from 14.2 for pre-tax income to 10.4 for post-tax income and 8.3 for post-tax plus transfer income. ${ }^{18}$ Optimal taxation of income

15. The "Retrospective Income Concept" was developed by Petska et al. (2000) to allow comparisons both before and after the major tax reforms and to provide a more uniform measure of income across tax years. Retrospective income is calculated by including the same income and deduction items in each years' income calculation using items available on federal individual income tax returns. Tax years 1979 through 1986 are used as base years to identify the income and deduction items that are then applied to later years so that the same income components are common to all years. The advantage of using the retrospective income concept (i.e. tax data) as opposed to Census-based data is that the former provides a more complete sampling of the highest income levels and it includes realised capital gains that are a large component of the revenues of upper income groups. However, welfare transfers and Social Security benefits are omitted from the tax data, which overestimate tax shares for the lowest income quintile.

16. Petska et al. (2000)'s estimates show that the Gini coefficients increased throughout the 19-year period for both the pre-tax and the post-tax income distributions. However, the federal income tax served to decrease the Gini coefficient for all years due to its progressive nature. Such a finding is also consistent with estimates on the distribution of income after taxes and transfers found using the Current Population Survey (Forster, 2000).

17. Although there is considerable body of evidence that supports the notion that tax changes are responsible for the increase in income inequality, Slemrod and Bakija (2000) argue that the fast rise of income shares of the wealthiest between 1994 and 1996 cannot be explained by tax factors, since no tax change took place in those years.

18. Life-time income inequality would likely be lower than inequality at a point in time, since there is considerable mobility across income categories from year-to-year. International comparisons of such mobility are difficult to make in the absence of comparable panel data. A comparison of the United States and Germany found there were "surprisingly similar patterns of quintile-to-quintile mobility" (Burkhauser, Holtz-Eakin and Rhody, 1997). 
25. In any tax system, a balance is drawn between the extent of the losses from efficiency and the gains to welfare that might accrue from the redistribution of income, as the marginal utility of lower income people is generally implicitly valued more highly by society than that of higher income people. Empirical progress in quantifying that balance in the United States has been limited. ${ }^{19}$ When making international comparisons of the balance between equity and efficiency though, it may be that the relative weights given to the utility of different income groups vary across countries. Some empirical support for such differences comes from a study that attempts to explain why people declare themselves to be more or less happy. In Europe, more inequality appears to reduce happiness, while this is the case to a much lesser extent in the United States (Alesina et al., 2001).

\section{Capital income taxation: a major area for reform}

26. The appropriate method for the taxation of capital income, consisting of the return to both financial physical and human capital, has been a perpetual source of legislative tension. There has been recognition that this form of taxation engenders a considerable deadweight loss to the economy. Against this, capital income accrues mainly to the rich and so, in the short-term, has been seen as a source of tax revenue that can be used to improve the situation of lower-income families. Different governments have accorded different priorities to distributional rather than efficiency arguments. The result has been a patchwork of tax rates on different sources of capital income, according to the legislators' view of the desirability of different types of assets. Thus, tax rates can vary between 65 per cent, for corporate income that is paid as dividends to a person living in a high income-tax state, and zero for interest from state and local government bonds. Interest and capital gains accumulated in a pension fund, and the imputed income from owner-occupied housing are also not taxed. By end-2000, 44 per cent of household assets were held in personal-income-tax-exempt forms. Such a variety of tax rates, depending on the type of asset and the entity holding the assets, may distort the pattern of economic activity at a given point in time, while the existence of any capital income taxation distorts activity over time.

19. Two researchers (Gruber and Saez, 2000) have proposed a methodology that attempts to estimate the social weights implied in the current income tax system and to dense an optimal tax system. According to them, an optional system might well involve lump-sum transfers to the poor that are taxed away quite rapidly and relatively low top marginal tax rates. 
ECO/WKP(2001)39

Table 7. Various estimates of taxable income elasticities

\begin{tabular}{|c|c|c|c|c|c|c|}
\hline $\begin{array}{l}\text { Author } \\
\text { (Date) }\end{array}$ & $\begin{array}{l}\text { Data } \\
\text { (Years) }\end{array}$ & Tax change & Sample & $\begin{array}{l}\text { Controls for mean } \\
\text { revision and income } \\
\text { distribution }\end{array}$ & $\begin{array}{l}\text { Income } \\
\text { definitions }\end{array}$ & $\begin{array}{l}\text { Elasticity } \\
\text { results }\end{array}$ \\
\hline $\begin{array}{l}\text { Lindsey } \\
\text { (1987) }\end{array}$ & $\begin{array}{l}\text { Repeated Tax Cross-sections } \\
\text { (1980 to 1984) }\end{array}$ & ERTA 81 & $\mathrm{AGI}>\$ 5 \mathrm{~K}$ & None & Taxable income & $\begin{array}{l}1.05 \text { to } 2.75 \\
\text { Central estimate: } 1.6\end{array}$ \\
\hline $\begin{array}{l}\text { Feldstein } \\
\text { (1995) }\end{array}$ & $\begin{array}{l}\text { NBER Tax Panel } \\
\text { (1985 and 1988) }\end{array}$ & TRA 86 & $\begin{array}{l}\text { Married, non-aged } \\
\text { non } S \text { corporation } \\
\text { creating income } \\
>\$ 30 \mathrm{~K}\end{array}$ & None & $\begin{array}{l}\text { AGI } \\
\text { Taxable income }\end{array}$ & $\begin{array}{l}0.75-1.3 \\
1.1-3.05\end{array}$ \\
\hline $\begin{array}{l}\text { Navratil } \\
\text { (1995) }\end{array}$ & $\begin{array}{l}\text { NBER Tax Panel } \\
\text { (1980 and 1983) }\end{array}$ & ERTA 81 & $\begin{array}{l}\text { Married, income } \\
>\$ 25 \mathrm{~K}\end{array}$ & Average income & Taxable income & 0.8 \\
\hline $\begin{array}{l}\text { Auten-Carroll } \\
\text { (1997) }\end{array}$ & $\begin{array}{l}\text { Treasury Tax Panel } \\
\text { (1985 and 1989) }\end{array}$ & TRA 86 & $\begin{array}{l}\text { Single and married } \\
\text { age } 25-55 \text {, have } \\
\text { income }>\$ 25 \mathrm{~K}\end{array}$ & Income in base year & $\begin{array}{l}\text { Gross income } \\
\text { Taxable income }\end{array}$ & $\begin{array}{l}0.66 \\
0.75\end{array}$ \\
\hline $\begin{array}{l}\text { Sammartino and } \\
\text { Weiner (1997) }\end{array}$ & $\begin{array}{l}\text { Treasury Tax Panel } \\
\text { (1985 and 1994) }\end{array}$ & $\begin{array}{l}\text { OBRA } \\
1993\end{array}$ & Less than 62 years & None & AGI & Close to zero \\
\hline $\begin{array}{l}\text { Goolsbee } \\
\text { (1996) }\end{array}$ & $\begin{array}{l}\text { Panel of Corporate } \\
\text { Executives } \\
\text { (1991 to 1994) }\end{array}$ & $\begin{array}{l}\text { OBRA } \\
1993\end{array}$ & $\begin{array}{l}\text { Corporate executives } \\
95 \text { per cent with } \\
\text { income }>\$ 150 \mathrm{~K}\end{array}$ & Average income & $\begin{array}{l}\text { Wages, bonus and } \\
\text { stock options }\end{array}$ & $\begin{array}{l}\text { Short-run: } 1 \\
\text { Long-run: } 0.1\end{array}$ \\
\hline $\begin{array}{l}\text { Carroll } \\
(1998)\end{array}$ & $\begin{array}{l}\text { Treasury Tax Panel } \\
\text { (1987 and 1996) }\end{array}$ & $\begin{array}{l}\text { OBRA } \\
1993\end{array}$ & $\begin{array}{l}\text { Married aged 25-55 } \\
\text { income }>\$ 50 \mathrm{~K}\end{array}$ & Average income & Taxable income & 0.5 \\
\hline $\begin{array}{l}\text { Saez } \\
(1999)\end{array}$ & $\begin{array}{l}\text { NBER Tax Panel } \\
\text { (1979 to } 1981)\end{array}$ & $\begin{array}{l}\text { Bracket } \\
\text { Creep }\end{array}$ & Married and singles & $\begin{array}{l}\text { Long and polynomials } \\
\text { in income }\end{array}$ & $\begin{array}{l}\text { AGI } \\
\text { Taxable income }\end{array}$ & $\begin{array}{l}0.25 \\
0.4\end{array}$ \\
\hline $\begin{array}{l}\text { Moffitt and } \\
\text { Wilhelm (2000) }\end{array}$ & $\begin{array}{l}\text { SCF Panel } \\
\text { (1983 and 1989) }\end{array}$ & TRA 86 & $\begin{array}{l}\text { High incomes } \\
\text { over-sampled }\end{array}$ & Various instruments & AGI & 0 to 2 \\
\hline $\begin{array}{l}\text { Goolsbee } \\
\text { (1999) }\end{array}$ & $\begin{array}{l}\text { Tax Statistics Tables } \\
\text { (1922 to 1989) }\end{array}$ & Various tax reforms & Income $>\$ 30 \mathrm{~K}$ & None & Taxable income & -1.3 to 2 \\
\hline $\begin{array}{l}\text { Gruber and Saez } \\
(2000)\end{array}$ & $\begin{array}{l}\text { NBER Tax Panel } \\
\text { (1979 to 1990) }\end{array}$ & $\begin{array}{l}\text { All state and federal } \\
\text { tax reforms in the } \\
1980 \text { s }\end{array}$ & $\begin{array}{l}\text { Married or singles } \\
\text { income }>\$ 10 \mathrm{~K}\end{array}$ & $\begin{array}{l}\text { Log income and } \\
\text { splines in income }\end{array}$ & $\begin{array}{l}\text { Consistent definition } \\
\text { of taxable income }\end{array}$ & 0.4 \\
\hline
\end{tabular}

Source: Gruber and Saez (2000). 
ECO/WKP(2001)39

Figure 9. Progressivity of the personal income tax
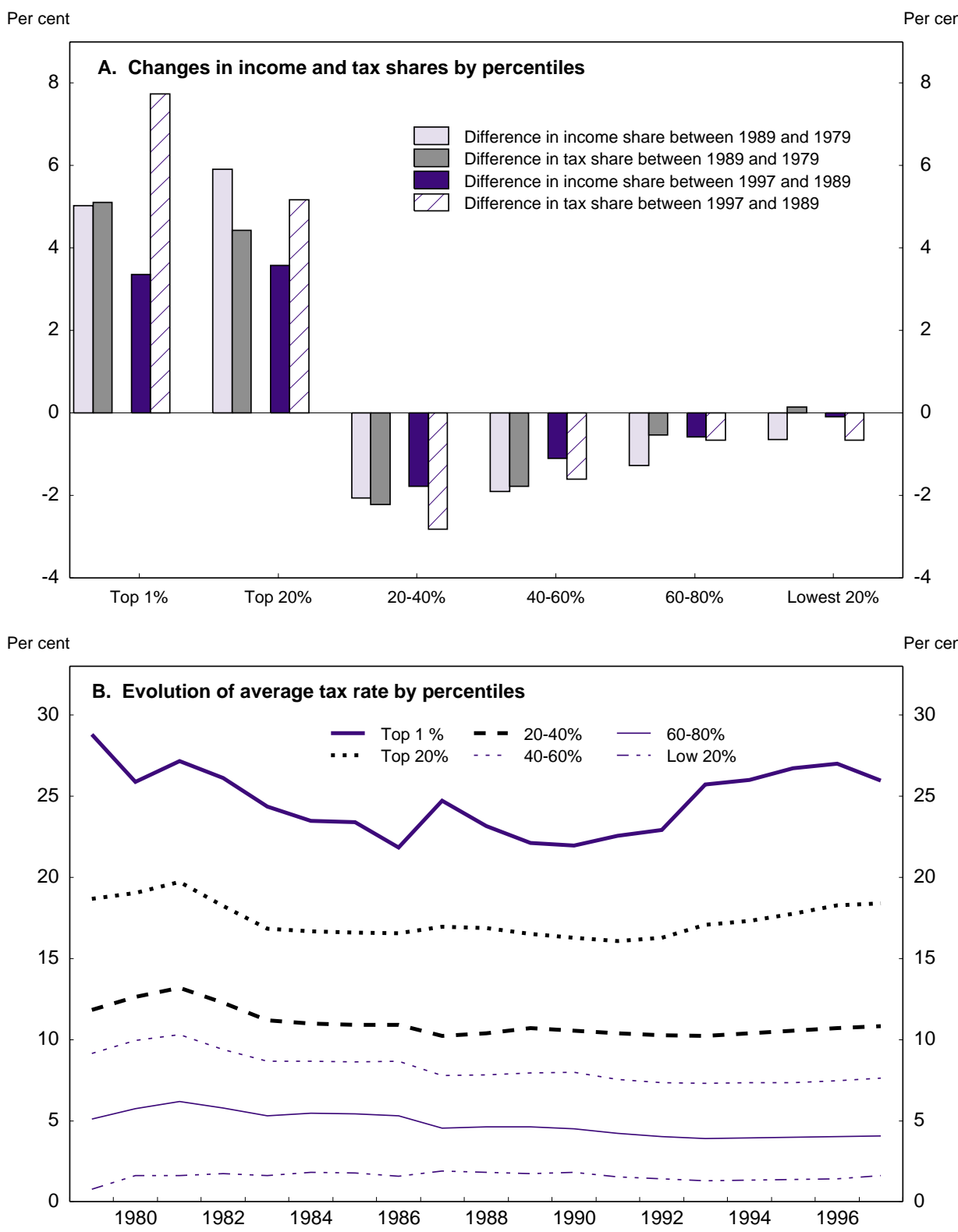

Source: Petska et al. (2000). 
Figure 10. Distribution of income after tax across countries

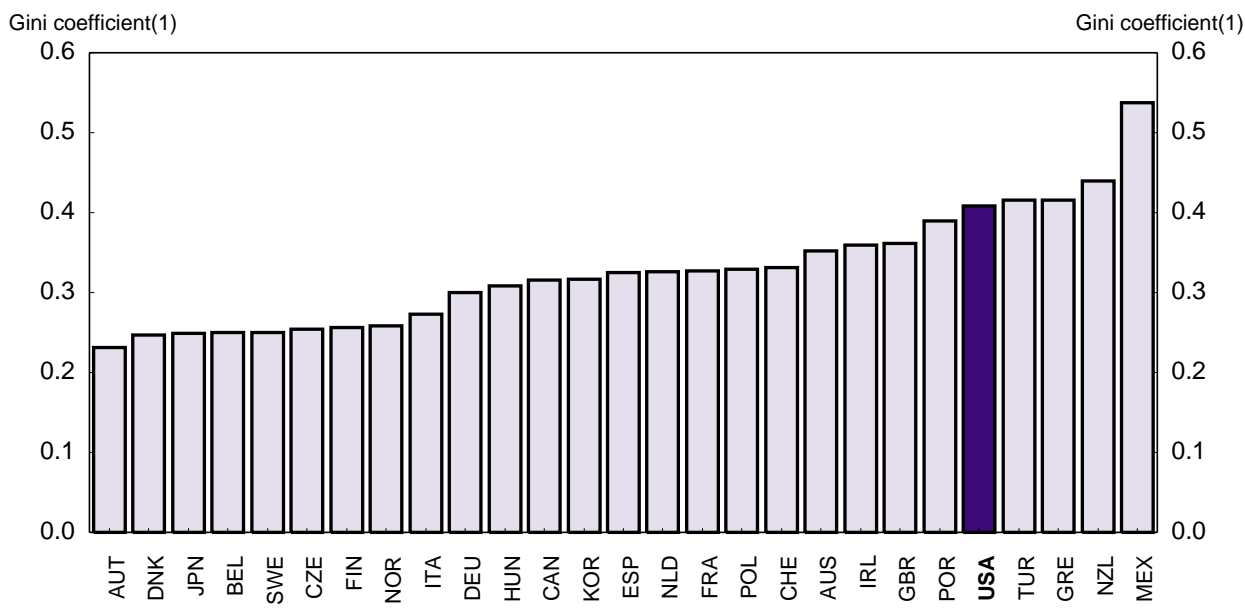

1. The Gini coefficient is a measure of income inequality: the higher the coefficient, the wider the income distribution. Gini coefficients are for 1997 or nearest year available.

Source: Anastassakou et al.(1999); REIS (2000) ; World Bank, World Development Indicators (2000).

Table 8. The distribution of tax liabilities and transfer payments 1994

\begin{tabular}{|c|c|c|c|c|c|}
\hline $\begin{array}{c}\text { Family expanded } \\
\text { income } \\
\text { percentile }^{1}\end{array}$ & $\begin{array}{l}\text { Current law, } \\
\text { average taxes }^{2}\end{array}$ & $\begin{array}{l}\text { Average } \\
\text { tax rates } \\
\text { Per cent }\end{array}$ & $\begin{array}{l}\text { Average } \\
\text { transfer } \\
\text { payments }\end{array}$ & $\begin{array}{c}\text { Taxes paid } \\
\text { minus transfers } \\
\text { received }\end{array}$ & $\begin{array}{l}\text { Average tax } \\
\text { rates including } \\
\text { transfers } \\
\text { Per cent }\end{array}$ \\
\hline $5-10$ & 175 & 2.7 & 1552 & -1376 & -21.0 \\
\hline $10-20$ & 627 & 6.1 & 1384 & -757 & -7.4 \\
\hline $20-30$ & 1686 & 10.8 & 669 & 1017 & 6.5 \\
\hline $30-40$ & 3159 & 14.8 & 226 & 2933 & 13.7 \\
\hline $40-50$ & 5023 & 18.2 & 188 & 4835 & 17.5 \\
\hline $50-60$ & 7145 & 20.5 & 90 & 7055 & 20.3 \\
\hline $60-70$ & 9785 & 22.5 & 63 & 9722 & 22.3 \\
\hline $70-80$ & 13284 & 24.4 & 88 & 13197 & 24.2 \\
\hline $80-90$ & 18562 & 26.4 & 48 & 18514 & 26.3 \\
\hline $90-95$ & 26714 & 29.0 & 64 & 26651 & 28.9 \\
\hline $95-99$ & 43375 & 31.3 & 31 & 43344 & 31.3 \\
\hline $99-100$ & 223953 & 41.6 & 0 & 223953 & 41.6 \\
\hline Total & 11834 & 25.8 & 376 & 11457 & 24.9 \\
\hline
\end{tabular}

Note: Data are from the 1999 Survey of Income and Program Participation, updated to 1994.

1. Family expanded income is wage and salary income, taxable interest and dividend income, alimony, business income, taxable pensions and annuities, rents, royalties, income from partnerships, income from estates and trusts, unemployment compensation, taxable social security, other miscellaneous income, non-taxable interest income, non-taxable pension income, non-taxable social security income, Aid to Families with Dependent Children, food stamps, Supplementary Security Income, employer-provided health insurance, and the employer-paid portion of payroll taxes and corporate taxes.

2. Taxes are federal individual and corporate income taxes, state income taxes, and payroll (OADSHI) taxes.

3. Transfer payments under current law, including AFDC, food stamps, and SSI.

Source: Gale et al. (1996). 


\section{The optimal taxation of capital income}

27. A large part of the economic literature has argued that the theoretically optimal rate of capital income taxation is zero (Hassett and Hubbard, 2001), but there are some provisos that have to be made to this claim. A tax on capital income changes the price of present and future consumption goods, and is the equivalent of imposing a growing tax on consumption in future time periods. Therefore, if the tax was optimal in the first period, an unchanged capital income tax implies a constantly growing distortion (Judd, 2001). If there were no other distortions in the economy, moving to an equal taxation of present and future consumption would improve efficiency. However, as income tax distorts labour supply, this move could only be guaranteed to improve efficiency if it did not further reduce labour supply. This is most easily seen by dividing consumption into two goods: one in the present and one in the future. If these two types of consumption are equally complimentary with leisure, there would be no change in labour supply and a consumption tax is better than an income tax. However, it is not clear that this is the case, and that limits the use of this insight for policy purposes (Heady, 1996). If it were the case, a further benefit of moving towards a consumption tax (Box 4) is that the tax differentials between risky and safe assets would be removed. It is not necessary, though, to shift to a consumption tax to achieve this result. Introducing neutrality between these types of assets into the present code could also achieve this result. Indeed up to half of the gain from a move to a consumption tax may stem from the elimination of this bias (Judd, 2001).

\section{Box 4. Benefits and costs from shifting to a consumption tax}

Proponents of consumption taxation have suggested abandoning the entire income tax system and replacing it by some form of consumption taxation. Such a tax could take many forms. It could be an income tax with a net saving allowance or an expenditure-based tax such as VAT, or an employment tax coupled with a cash-flow tax for companies. No country has opted to rely solely on such a tax; nonetheless, the academic literature generally shows it to be superior to an income tax. It has been advocated as a particularly promising route for countries that face strong growth in revenue needs in the future (Auerbach, 1997). It is also expected to increase welfare and real incomes (Boskin, 1996 and Congressional Budget Office, 1997). A significant part of the benefit from a consumption tax would come from the implied one-off levy on existing capital. If governments can commit to not repeating such a levy, then this a very efficient form of taxation. Any move to compensate holders of existing capital reduces the gain from the shift to a consumption tax.

A move towards consumption taxation would have negative consequences for the holders of existing capital. This might have disruptive transition effects. The extent of the size of the transition costs has been a matter of extensive debate (see Hassett and Hubbard, 2001). Many have argued that the housing market would be particularly affected, as mortgage-interest and property-tax deductions would be eliminated under a consumption tax. In the short term, such a fall seems likely, with one paper in the cited collection implying a fall of 6 per cent in the real price of structures and a 19 per cent fall in real land prices. To the extent that financial asset values reflect investment in intangibles that have already expensed, there would be less of a fall in profits and, therefore, the fall in equity values would be lowered. Equally if old and new capital were complementary, then transition costs would be lower, but this might also lower long-term gains from introducing a consumption tax. 
A consumption tax could be implemented in a number of ways with varying distributional consequences, both in the short- and long-term. ${ }^{1}$ One approach that has been advocated is to entirely replace income taxation by a uniform national sales or value-added tax. The initial consequences of such a move would appear to be particularly adverse for low-income groups and could raise effective tax rates for all but the highest 10 per cent of income-earners at a given point in time. Over the longer term, though, there is considerable movement between income categories and lower income categories gradually accumulate assets. Even taking into account the lifetime earnings distribution, some models suggest the lowest income category would experience a reduction in income. The overall welfare gain from such a policy change are estimated to be extremely large (Jorgenson and Yun, 2001), giving room to compensate the latest income groups for their losses. Other approaches to the introduction of a consumption tax are possible that would have less impact on low-income groups. These approaches essentially involve taxing personal income less net saving, corporate cash flow as well as a small value-added tax. In these cases a consumption tax could be progressive. In the long term, such taxes appear to still improve income. All of these changes would have significant transitional costs, especially for the generation that has just retired when the tax base is changed.

1. This section draws on the various simulation presented in Aaron and Gale (1996).

28. There has, though, been considerable controversy about the magnitude of the elasticities involved, in particular as to whether private savings would respond to a higher post-tax rate of return. Theoretically it is not clear whether people would increase saving in response to a higher return. ${ }^{20}$ Studies of tax-favoured saving plans have arrived at opposite conclusions about whether tax-preferred retirement plans stimulate saving, though they concur that households with high income and wealth or the ratio of wealth to income were more likely to use such plans. Some authors have found that the sample population participating in these programmes increased their total assets over time, that nearly all of this increase was in tax-favoured forms, and that at the same time non-tax favoured saving plans did not decline (Poterba, Venti and Wise, 1996). This was true even after controlling for age and income effects. Others have found that tax-favoured accounts had little measurable effect on aggregate personal saving (Gale, Engen and Sholz, 1996). They inferred that higher saving in these accounts was mostly asset reallocation. Any positive saving effect was largely explained by the increase in income implied by the tax break involved (Kohl and O'Brien, 1998). Provided that the government has a goal for public-sector savings, as is the case in the United States, such programmes would not decrease the government surplus. Moreover, there is some disagreement as to whether the goal of tax incentives for saving should be to increase aggregate saving or to create incentives for saving in a form that cannot easily be reversed in order to forestall myopic consumers. The case for non-reversible incentives rests on consumption models in which the discount rate increases with time (known as hyperbolic discounting) ${ }^{21}$ However, these objectives are not mutually exclusive: incentives for specific kinds of saving could increase national savings. However, in a period when incentives have been increasing, the personal saving rate has declined and is lower than in almost all other OECD Member countries, though part of the decline is like to be definitional and linked to the rise in the valuation of equities (see OECD, 2001).

29. Part of employment income represents a return to an investment in human capital through education or training. The same arguments about incentives and distortions of choice through time apply to investment in this area as well as investment in financial capital. It is, however, difficult to distinguish the part of employment income that is a return to human capital. Consequently, the best way to reduce the distortion is to allow investment in education to be made out of pre-tax income, or to treat education

20. While the tax on saving creates an incentive to substitute consumption today for less in the future, it also makes the taxpayer effectively poorer, which would tend to reduce consumption today.

21. See Laibson (1996) for an explanation of the consequences of this type of behaviour. 
outlays on the same basis as investment in a consumption tax. Practically, this would involve the tax deductibility of education spending. ${ }^{22}$ The US tax system already allows substantial deductibility of education expenditure but from parents' tax bills, rather than students'. Moreover, within certain limits, the interest on the deductibility of loans used to finance education spending is tax-deductible. The 2001 tax law goes further in this direction by extending a number of allowances and permitting withdrawal from a number of tax-favoured savings schemes to finance education.

\section{Taxation of companies: a double burden}

30. Corporate taxation is not high in the United States. The top statutory rate for federal corporate taxation is in the middle range of OECD rates. Moreover, the tax code allows for a variety of different tax treatments for limited-liability entities. The major distinction in this domain is between companies that are regarded as "pass-through" vehicles and that are not subject to taxation in their own right but are taxed in the hands of their owners under income taxation, and structures that are taxed in their own right. Amongst the former, there are three types: "S" corporations, whose main distinguishing feature is that they can have no more than 75 shareholders, none of which can be a non-resident alien. There are also a number of other structures such "LLC" companies and "LLP" partnerships. The first of these is a relatively new construct and is limited to non-publicly traded entities. In the past decade, nearly all of the growth of in the number of limited liability entities has been in the form of pass-through structures. The number of classic corporations has stagnated (Figure 11). Finally, real estate investment trusts and regulated investment companies (mutual funds) pay corporate tax only to the extent that all income is not distributed to the owners each year.

\section{Figure 11. Number of limited liability entities by structure and tax regime ${ }^{1}$}

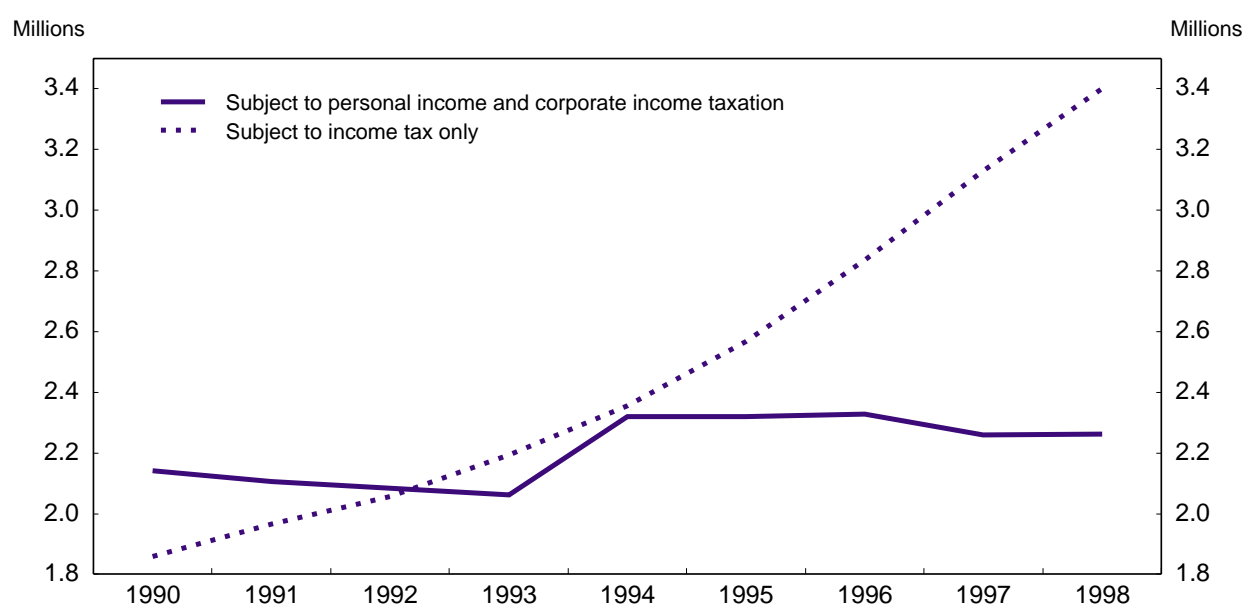

1. Limited liability entities include "C" corporations, "S" corporations, "LLC" companies and "LLP" partnerships. Only the first in the list are subject to both corporate and income taxation.

Source: Joint Committee on Taxation (2001a). 
31. Four tax acts since 1986 have spurred these types of pass-through arrangements. The income of "S" corporations, for example, growth at an average annual rate of 10 per cent between 1987 and 1997. In addition, sole proprietorships and general partnerships, real-estate investment trusts and regulated investment companies (mutual funds) are taxed on a pass-through basis. Overall, only 53 per cent of enterprise income is subject to corporate income tax (Table 9). The income of these entities accounted for around about 11.2 per cent of GDP in 1997, against 8.6 per cent of GDP for classic corporations. The prevalence of these pass-through arrangements may explain why federal tax revenue is somewhat lower than the OECD average of 3.3 per cent of GDP (Figure 12). ${ }^{23}$ Another factor may be the extensive foreign investments of US companies that generate considerable tax credits. ${ }^{24}$

\section{Corporate taxation: the main features}

32. Classic corporations and their shareholders bear the heaviest burden of capital income taxation. The tax schedule for classic corporations has marginal rates that increase with the net income of the company, with the top rate, at 35 per cent, applying to corporations with taxable income above $\$ 10$ million. However, the benefits of the low tax rates are phased out as net income increases. The result is that the principal benefit of low tax rates goes to corporations that have net income below $\$ 335000 .{ }^{25}$ Between that level of income and the rate at which the standard rate kicks in, corporations are taxed at 34 per cent, scarcely any different from the standard rate. Like the personal tax code, the corporate tax system has its own AMT that is intended to ensure that all corporations pay tax, even those benefiting from extensive tax breaks. The AMT applies a lower tax rate of 20 per cent to a broader definition of taxable income. Companies are liable for the greater of the AMT and the regular tax. This provision affects a minority of corporations.

33. Despite the availability of pass-through company structures, the majority of classic corporations are small. Corporations with less than $\$ 5$ million of gross assets (and broadly having net income below $\$ 300$ 000) amounted to almost 94 per cent of all companies in 1997 (Contos and Legel, 2000). However, they accounted for only just over 6 per cent of net income and less than 4 per cent of total corporate tax payments. The distribution of profits within all corporations is extremely concentrated, with the largest 9000 companies, those having assets of over $\$ 250$ million, accounting for 84 per cent of corporate tax payments. These companies paid an average effective federal tax rate of 27 per cent. Companies with assets between $\$ 5$ million and $\$ 250$ million paid a slightly higher effective tax rate of just over 28 per cent. The difference between the statutory rate and the actual rate is accounted for by tax credits, principally that for tax paid abroad.

\footnotetext{
23. This is indicative only since no account is taken of differences across countries in the composition of GDP or taxation of income not included in GDP. National statistics put the yield of the federal corporate tax at 2.1 per cent of GDP in 2000 .

24. The state corporate tax adds to the federal, but at the individual state level it is levied in proportion to a mix of labour, capital and sales.

25. This concession cost $\$ 6.5$ billion in 2000 , about 3 per cent of the total corporate tax yield.
} 
Table 9. Net income of business enterprises and corporate tax payments

A. Net income of enterprises by structure

Enterprises subject to income tax only Limited liability

S Corporations

Limited liability partnerships

Limited liability companies

Unlimited liability

General partnerships

Non-farm sole proprietorships

Investment companies

Real estate investment trusts

Regulated investment trusts

Enterprises subject to income and corporate taxation Classic corporations

\section{All enterprises}

(Pass-through structures as per cent of total enterprise income)

\section{B. Analysis of corporate tax payments}

Profits of classic corporations

Income not subject to further tax

Income subject to tax

Total income tax before credits

Foreign tax credit

US possessions tax credit

Non-conventional source fuel credit

General business tax credit

Prior year minimum tax credit

Total income tax after credits

Corporate income tax rate before credits

Corporate income tax rate after credits

\begin{tabular}{|c|c|c|c|c|}
\hline 1996 & \multicolumn{2}{|c|}{1997} & 1996 & 1997 \\
\hline \$ billion & \$ billion & $\begin{array}{l}\text { Per cent } \\
\text { change }\end{array}$ & \multicolumn{2}{|c|}{ Per cent of GDP } \\
\hline 775.2 & 928.6 & 19.8 & 9.9 & 11.2 \\
\hline 193.0 & 233.1 & 20.8 & 2.5 & 2.8 \\
\hline 125.2 & 153.1 & 22.2 & 1.6 & 1.8 \\
\hline 55.5 & 62.9 & 13.5 & 0.7 & 0.8 \\
\hline 12.3 & 17.1 & 38.6 & 0.2 & 0.2 \\
\hline 73.5 & 79.8 & 8.5 & 0.9 & 1.0 \\
\hline 176.8 & 186.6 & 5.5 & 2.3 & 2.2 \\
\hline 7.8 & 20.3 & 160.3 & 0.1 & 0.2 \\
\hline 131.0 & 175.8 & 34.2 & 1.7 & 2.1 \\
\hline 667.7 & 719.3 & 7.7 & 8.5 & 8.6 \\
\hline 1442.9 & 1647.9 & 14,2 & 18.5 & 19.8 \\
\hline (53.7) & (56.4) & - & - & - \\
\hline 667.7 & 719.3 & 7.7 & 8.5 & 8.6 \\
\hline 27.9 & 35.5 & 27.3 & 0.4 & 0.4 \\
\hline 639.8 & 683.8 & 6.9 & 8.2 & 8.2 \\
\hline 223.7 & 239.4 & 7.0 & 2.9 & 2.9 \\
\hline 40.2 & 42.2 & 5.0 & 0.5 & 0.5 \\
\hline 3.1 & 2.7 & -12.2 & 0.0 & 0.0 \\
\hline 0.9 & 1.1 & 20.4 & 0.0 & 0.0 \\
\hline 4.2 & 5.1 & 21.1 & 0.1 & 0.1 \\
\hline 4.7 & 4.1 & -12.2 & 0.1 & 0.0 \\
\hline 170.6 & 184.2 & 8.0 & 2.2 & 2.2 \\
\hline 35.0 & 35.0 & - & - & - \\
\hline 26.7 & 26.9 & - & - & - \\
\hline
\end{tabular}

Source: Internal Revenue Service (2000). 
Figure 12. Taxation of corporate income in OECD countries 1999

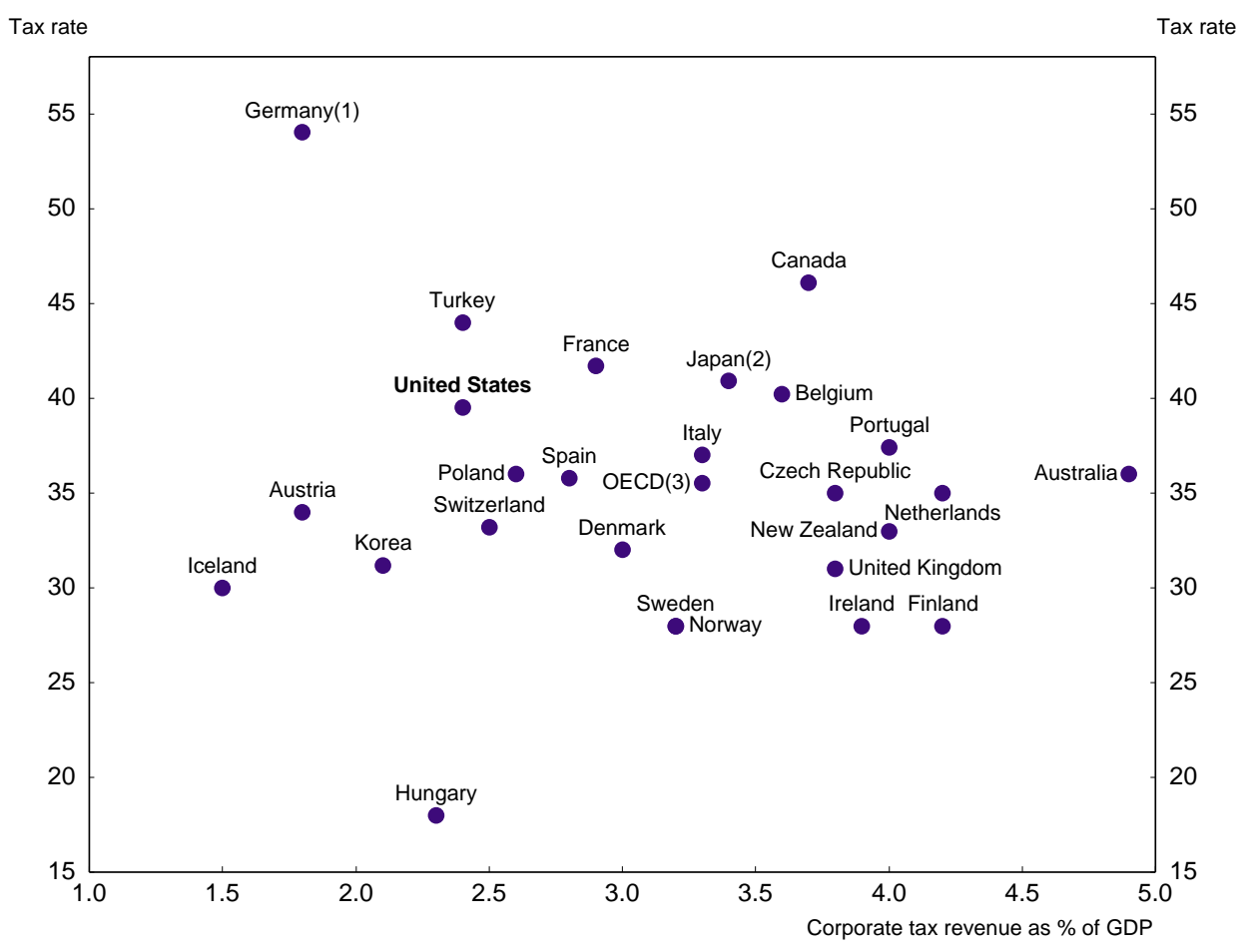

1. Tax rate on retained earnings.

2. The rates are net of the tax abatement.

3. Unweighted average.

Source: OECD, Revenue Statistics, 2001; OECD Tax Database.

\section{Lack of neutrality in corporate financing decisions}

34. The interplay of the corporate and the personal income tax system introduces a bias in favour of bond financing and discourages the payment of dividends. Marginal effective tax wedges across various financing vehicles exhibit more variability than other OECD Member countries, while the level of the tax wedge for equity is amongst the highest in the area. There is a bias in favour of debt finance and retained earnings (Table 10). This is the result of pre-tax profits being taxed both at the corporate stage and as dividends to shareholders under the personal income tax. ${ }^{26}$ However, even retained earnings are taxed twice, as they raise the share value of the company and generate a capital gain that is taxed. On the other hand, interest payments are taxed only in the hands of the recipient. Indeed the extent of the dispersion in taxation across financing methods in the United States is amongst the highest in OECD countries (Table 10).

26. See also Gravelle (1995) for a summary of the economic issues and policy options put forward by the Treasury to remedy this situation. 
ECO/WKP(2001)39

Table 10. Marginal effective corporate tax wedges in manufacturing by source of financing ${ }^{1}$ In per cent, 1999

\begin{tabular}{lccc|cc}
\hline & \multicolumn{3}{c|}{ Sources of financing $^{2}$} & \\
\cline { 2 - 3 } & $\begin{array}{l}\text { Retained } \\
\text { earnings }\end{array}$ & $\begin{array}{c}\text { New } \\
\text { equity }\end{array}$ & Debt & \multirow{2}{*}{ Standard deviation $^{3}$} \\
\cline { 2 - 3 } New Zealand & & & & \\
Norway & 1.48 & 1.48 & 1.48 & 0.00 & $(1)$ \\
Mexico & 1.06 & 1.06 & 1.06 & 0.00 & $(1)$ \\
Denmark & 0.77 & 1.04 & 1.04 & 0.13 & $(3)$ \\
Italy & 1.89 & 2.43 & 2.49 & 0.27 & $(4)$ \\
Korea & 1.27 & 1.27 & 0.39 & 0.41 & $(5)$ \\
United Kingdom & 0.61 & 1.59 & 1.59 & 0.46 & $(6)$ \\
Australia & 2.88 & 2.40 & 1.55 & 0.55 & $(7)$ \\
Finland & 2.02 & 0.81 & 2.11 & 0.59 & $(8)$ \\
Spain & 2.20 & 0.85 & 0.85 & 0.64 & $(9)$ \\
Germany & 3.20 & 2.23 & 1.65 & 0.64 & $(10)$ \\
Greece & 0.89 & 2.53 & 1.28 & 0.70 & $(11)$ \\
Luxembourg & 0.92 & 0.92 & -0.58 & 0.71 & $(12)$ \\
Sweden & 3.57 & 2.37 & 1.62 & 0.80 & $(13)$ \\
Iceland & 2.07 & 2.83 & 0.77 & 0.85 & $(14)$ \\
Austria & 1.82 & 2.28 & -0.08 & 1.02 & $(15)$ \\
Portugal & 0.74 & 2.65 & 0.06 & 1.10 & $(16)$ \\
Switzerland & 1.13 & 2.50 & -0.25 & 1.12 & $(17)$ \\
Belgium & 0.38 & 3.49 & 1.81 & 1.27 & $(18)$ \\
Ireland & 1.36 & 2.54 & -0.60 & 1.29 & $(19)$ \\
Canada & 1.52 & 4.12 & 0.69 & 1.46 & $(20)$ \\
United States & 4.48 & 5.63 & 1.98 & 1.52 & $(21)$ \\
Netherlands & $\mathbf{1 . 6 6}$ & $\mathbf{4 . 7 9}$ & $\mathbf{1 . 4 2}$ & $\mathbf{1 . 5 4}$ & $(\mathbf{2 2})$ \\
Japan & 0.46 & 5.33 & 2.46 & 2.00 & $(23)$ \\
France & 3.30 & 5.50 & -0.09 & 2.30 & $(24)$ \\
OECD & 3.58 & 7.72 & 0.67 & 2.89 & $(25)$ \\
EU & 2.02 & 4.03 & 1.09 & 1.23 & \\
\hline & 1.95 & 3.24 & 1.01 & 0.91 & \\
\hline
\end{tabular}

1. These indicators show the degree to which the personal and corporate tax systems scale up (or down) the real pre-tax rate of return that must be earned on an investment, given that the household can earn a 4 per cent real rate of return on a demand deposit. Wealth taxes are excluded. See OECD (1991), Taxing Profits in a Global Economy: Domestic and International Issues, for discussion of this methodology. Calculations are based on top marginal tax rates for the personal income tax and a 2 per cent inflation rate.

2. The weighted average uses the following weights: machinery 50 per cent, buildings 28 per cent, inventories 22 per cent.

3. The number in parentheses indicates the country rank according to the standard deviation in descending order. Hence countries with a low ranking number have comparatively neutral tax systems with respect to corporate funding.

4. Weighted average across available countries (weights based on 1995 GDP and PPPs).

Source: OECD.

\section{Corporate tax deductions}

35. There are a number of deductions that lessen the tax burden on certain businesses, including a number of programmes adapted to exports. They vary from deductions and credits for research and development to incentives for small businesses. Accelerated depreciation is a major outlay but may not 
represent a true deduction. ${ }^{27}$ Few new tax expenditures had been introduced in the 5 years to FY 2000. These include the so-called "enterprise zones" created in 1997, renewal zones in 1998 and renewed community areas in 1999. Some additional measures to favour family firms and small businesses were also introduced (e.g. up to $\$ 25000$ of new capital equipment can be deducted if profits are below $\$ 200000$ ). The cost of the research credit is expected to be $\$ 6.1$ billion in 2001 .

36. A significant change in the tax treatment of foreign revenues was introduced by the Extraterritorial Income Exclusion Act. In the past, the use of foreign sales corporations (FSCs) allowed a 15 to 30 per cent exemption from corporate taxation of export sales. The FSC regime was replaced by the Extraterritorial Income Exclusion Act on 15 November $2000 .{ }^{28}$ This law considerably widens the scope of the possible tax deduction. The law gives the same tax exemptions to goods that are produced domestically for export as to goods that are made and sold abroad by US companies. According to the FY 2002 budget documents, this new tax break will be 15 per cent more expensive than its predecessor, costing $\$ 4.5$ billion per year.

37. US companies can defer the recognition of the income of their controlled foreign corporations, until it is repatriated, thereby postponing US taxation. Under these circumstances, if host countries of subsidiaries of US companies tax profits at a lower rate than that on investment income in the United States, then there is an incentive to defer taxation in the United States indefinitely. This tax break is estimated to cost $\$ 6.6$ billion in 2001. Such a strategy has become more profitable because the average host country tax rate on the income of foreign manufacturing subsidiaries declined from 33 per cent in 1980 to 21 per cent in 1996 (US Department of the Treasury, 2000), with no doubt further declines since then. By comparison, the average tax rate on domestic income of US manufacturing corporations was 31 per cent in 1996. This appears to have led to an international reallocation of assets, with the percentage of assets of US manufacturing subsidiaries in countries where the average effective tax rate was less than 29 per cent rising to 80 per cent in 1996 from only 40 per cent in 1980. Overall, the tax breaks from the FSCs, deferred taxation on foreign earnings and other small benefits amounted to about one percent of the value of exports and 31/4 per cent of the pre-tax profits for manufacturing industry in 1996 (Desai and Hines, 2000).

\section{State corporate taxation}

38. The state corporate income tax is only nominally a tax on the profit earned by a company in a given state. The tax is based on an apportionment formula by which companies allocate their national income across state tax jurisdictions. States have long used a formula that accords equal weight to three factors: payroll, property and sales. Such a formula effectively transforms the tax into a combination payroll, sales and property tax (McClure, 1980). Recently individual states have increased the weight of the sales factor and reduced the weight on payrolls and property, in the hope of attracting new employment. The use of destination- rather than origin-based indicators represents an attempt to generate economic development at the expense of other states. ${ }^{29}$ On average, the states that have lowered the payroll

27. Accelerated depreciation of machinery and equipments cost $\$ 33$ billion in 2001. Estimates by Brazell and Mackie (2001) show that the combination of normal and accelerated tax depreciation is only slightly more than economic depreciation. Moreover, economic depreciation rates were last estimated 20 years ago and may have increased since.

28. The FSC regime has been ruled to be an impermissible export subsidy by the World Trade Organisation (WTO) in February 2000 (see OECD, 2001). The OECD Forum on Harmful Tax Practices listed the FSC regime as a potentially harmful tax practice in the same year. The new regime itself was found to be in contravention of the WTO in August 2001, but that ruling is under appeal (see OECD, 2001).

29. If some fraction of firms' sales is within the state of production, the sales weight is not purely destination based. If the fraction is high, it becomes effectively an origin-based tax. 
weight have increased employment, with aggregate employment effects across the whole country close to zero (Goolsbee and Maydew, 1998). ${ }^{30}$ Since each state faces the same incentives, promoting uniformity in the apportionment formula, as among Canadian provinces, might improve welfare in the nation as a whole. Incentives for location are used extensively. In recent years every state has either enacted or significantly expanded one or more tax incentives with respect to business location (Enrich, 1998). Incentives cause other states to adopt retaliatory incentive measures, imposing high costs and further shrinking the aggregate tax base. However, this form of tax competition can lead to lower tax rates for all corporations.

\section{Taxation of personal capital income: a varied treatment}

39. Personal capital income is subject to a variety of different treatments. The income flows from some assets is totally exempted from taxation, some are taxed fully, while yet others are fully taxed as income, having been already taxed in corporations. The taxation of the income from a given financial asset depends on the legal structure in which the asset is held, creating horizontal inequities. Moreover, investors have to make careful decisions as to the structure in which different classes of assets should be held in order to minimise taxation. These rules lead to complexity and inefficiencies.

\section{Preferential treatment of pension plans and long-term savings}

40. The tax system provides a wide variety of tax-preferred retirement savings accounts. These various plans usually combine deduction of contributions from taxable income, tax-free interest accumulation during the life of the plan and then taxation of the proceeds when the plan is terminated (details of the numerous US plans are given in OECD, 1999). Such treatment, in effect, moves the income tax towards a consumption tax, on the assumption that a withdrawal from a retirement plan is used to finance consumption. However, other savings schemes such as allowing interest income to build up tax-free in a so-called Roth IRA, where saving is from post-tax income but withdrawals are tax-free, also moves the system from an income tax towards a consumption tax. Indeed for low-income households, whose saving rate is normally modest, current ceilings mean that they could be effectively taxed on a consumption basis rather than an income basis. In addition, there are a number of schemes that, while not allowing deductibility of contributions, do allow interest to be accumulated tax-free within the plan.

\section{Preferential treatment of owner-occupied housing}

41. The income from owner-occupied housing is also taxed at a zero rate. A substantial part of households' wealth is represented by housing, which may in part be explained by generous tax breaks. Indeed, 67 per cent of households owned their principal residence in $1999 .{ }^{31}$ The major tax breaks for housing comprise the exemption of imputed rents and the failure to tax most of the capital gains on such housing. ${ }^{32}$ In addition, the interest payments on mortgages of less than $\$ 1$ million, secured against an

30. Goolsbee and Maydew (1998) find that for the average state, reducing the payroll weight from one-third to one-quarter increases manufacturing employment by approximately 1.1 per cent in the long run ceteris paribus.

31. Overall, the relative weight of real estate in household assets has fallen somewhat over the last decade as a result of the sharp increase in the price of equities and other financial assets, but it still accounted for 20 per cent of total gross household assets at end-2000.

32. Up to $\$ 250000$ ( $\$ 500000$ for a married taxpayer filing a joint return) of capital gains on a sale of a principal residence is exempt from tax. This effectively exempts most housing from capital gains since the median value of the house held by the most wealthy 10 per cent of the population was still only $\$ 250000$ in 1998 (Kennickell et al., 2000). 
owner-occupied house, can be deducted from gross income, if the borrower opts for itemised tax deductions. In practice, only one-quarter of all tax filers have both mortgages and incomes sufficiently large to warrant itemisation, thereby skewing benefits to the better off. Over a lifetime, however, a greater proportion of filers are likely to have claimed the deduction. Under a complete income tax, all net capital income would be taxed under the same schedule and so interest payments should be deductible from imputed income. Indeed, one problem with the current tax system is that the taxpayer has to show that a particular investment was funded by a given loan before the interest is deductible. A major simplification would be to allow any interest paid to be deducted from interest received. Of course, imputed income from owner-occupied housing is not taxed, and may never be so in view of the difficulty of establishing appropriate rental levels, thus strengthening the case for the abolition of the mortgage interest deduction. Mortgage interest should, however, continue to be deductible from the income from other financial assets, otherwise there would be a discrimination between a person who funded a purchase from a loan and one who financed the same purchase from the disposal of a financial asset. Given this difficulty, the general trend among OECD Member countries is to phase out mortgage interest relief. The United Kingdom has already phased it out in full; progress has been more modest in Denmark, France, the Netherlands, and Spain. Nonetheless, ending this tax break would lower the real price of land substantially in the short term (Bruce and Holtz-Eakin, 2001). Consequently, moves to abolish the allowance, as with a shift to a consumption tax, could have transition costs that would depend on whether the deduction is eliminated as a change in the income tax system or as a part of an introduction of a value-added tax.

42. The favourable tax treatment of owner-occupied housing and the ability to offset mortgage interest against taxable income induce a number of distortions. It is generally accepted that tax-related subsidies increase the consumption of land and housing and result in a less dense pattern of development. Overall, the benefits of the tax programme are very concentrated geographically: six metropolitan areas ${ }^{33}$ receive just over half of gross tax benefits. They account, however, for only 29 per cent of all owner-occupied units (Gyourko and Sinai, 2001).

\section{Capital gains}

43. The taxation of capital gains is one of the most complex areas of income taxation (Joint Committee on Taxation, 2001b). Such complexity occurs because capital gains are generally taxed at a marginal rate lower that the marginal rate on other forms of income. There has been, and continues to be, pressure to transform income that would otherwise be taxable as ordinary income into capital gains. As result, legislators are constantly trying to block newly discovered transformation routes. Provisions that allow gains to be taxed at different rates also introduce complexity. These vary according to the period for which assets are held, and when they were acquired. Taking into account differences generated by type of asset and whether the assets are located in business expansion zones, capital gains are taxed at no fewer than 22 different rates. Gains on assets held for less than twelve months are taxed as ordinary income, gains held between 12 and 60 months are taxed at 20 per cent, while assets held for longer will be taxed at only 18 per cent as from 2005. Capital gains are extremely concentrated. The top 400 tax payers accounted for 11.8 per cent of all tax paid on capital realised gains in 1998, up from 4.9 per cent of the total in 1992. For this group, capital gains represented 85 per cent of their income (Slemrod, 2001).

33. San Francisco-Oakland-San Jose, Los Angeles-Riverside-Orange Country, New York City-New Jersey, Boston, Washington, D.C. and Chicago. 


\section{Taxation of the transfer of wealth}

44. Transfers of wealth are subject to the federal estate and gift tax. In 2000, federal estate and gift tax collection provided about $\$ 29$ billion in revenue (about 0.3 per cent of GDP), much higher than in most countries (Figure 13). The United States and the United Kingdom are the only OECD Member countries to levy a "pure" estate tax. The majority levy an inheritance tax, while Switzerland and Italy levy taxes that have some features of both inheritance and estate taxes. ${ }^{34}$ The United States also imposes a generation-skipping tax in addition to any estate or gift tax liability on certain transfers to generations two or more younger than that of the transferor. This effectively raises the marginal tax rates on affected transfers. Under the 2001 Economic Growth and Tax Relief Reconciliation Act the estate tax will be repealed in 2010. The current estate tax credit will rise to $\$ 2$ million, which has the effect of raising the lowest tax rate to 46 per cent by 2006, as the thresholds for the payment of the different tax rates remain unchanged. Three countries have abolished transfer taxes: Canada abolished the federal capital transfer tax in 1972 and replaced it with a tax on accrued gains at death; Australia phased out its estate tax starting in 1977 and New Zealand in 1992; the Italian government submitted a proposal to abolish inheritance taxes to Parliament in 2001, while France extended lower inheritance rates to domestic partners who are not married.

Figure 13. Estate, inheritance and gift taxes': an international comparison As a percentage of GDP, 1999

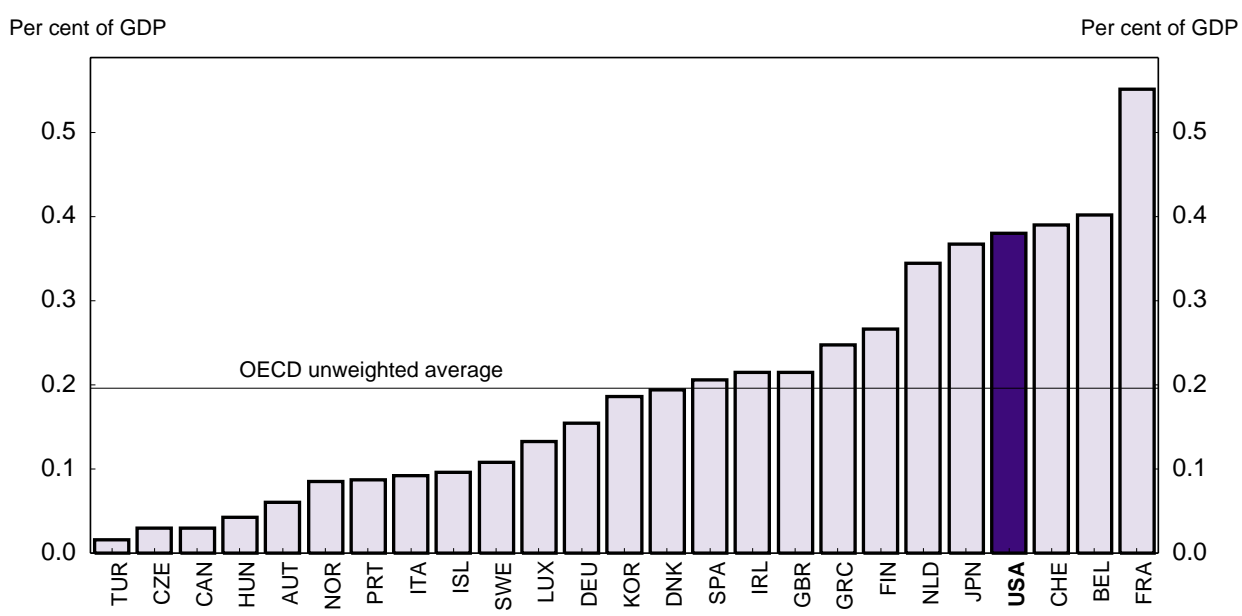

1. Periodic wealth taxes are not included.

Source: OECD, Revenue Statistics, 2001.

45. Estate taxes in the United States are much more progressive than the personal income tax, and the marginal tax rates are very high. The federal estate and gift tax is payable by just the largest 2 per cent of estates held by adults at death and effectively only households in the top income quintile. Its incidence is much more concentrated than the personal income tax (Table 11). The lowest rate of the federal estate tax

34. In Switzerland, transfer taxes are imposed at sub-federal levels. Ten US States also levy inheritance taxes. Most states levy only a "pick-up" estate tax, equal to the federal estate death tax credit. This allows the states to collect estate tax revenue without increasing the individual's overall estate tax burden. (However, the state credit is scheduled to be reduced between 2002 and 2004, and then replaced with a deduction in 2005.) 
Table 11. Estimated distribution of income and estate taxes 2000

\begin{tabular}{lcc|cc}
\hline & \multicolumn{2}{c|}{ As a per cent of income } & \multicolumn{2}{c}{ Allocation of total tax burden } \\
\cline { 2 - 5 } $\begin{array}{c}\text { Income quintile } \\
\text { or percentage }\end{array}$ & $\begin{array}{c}\text { Estate and } \\
\text { gift taxes }\end{array}$ & $\begin{array}{c}\text { Individual } \\
\text { income tax }\end{array}$ & $\begin{array}{c}\text { Estate and } \\
\text { gift taxes }\end{array}$ & $\begin{array}{c}\text { Individual } \\
\text { income tax }\end{array}$ \\
\hline & & & & \\
Lowest & 0.0 & -2.4 & 0.0 & -0.6 \\
Second & 0.0 & 0.8 & 0.0 & 0.5 \\
Third & 0.0 & 5.6 & 0.0 & 6.9 \\
Fourth & 0.0 & 7.8 & 9.8 & 76.3 \\
Highest & 0.5 & 13.7 & 96.2 & 61.3 \\
$\quad$ Top 10 per cent & 0.7 & 15.4 & 91.0 & 49.1 \\
Top 5 per cent & 0.9 & 16.9 & 64.2 & 29.5 \\
Top 1 per cent & 1.3 & 20.2 & 100.0 & 100.0 \\
All & & & & \\
\hline
\end{tabular}

Note: The distribution of income in 2000 was estimated using the Treasury Industrial Tax Model.

Source: Cronin (1999).

effectively applied (after taking into account the lifetime tax credit that is equal to the tax payable on an estate of $\$ 675000$ in 2001$)^{35}$ starts at 37 per cent, and the graduated rates range up to 55 per cent, which is reached for estates worth $\$ 3$ million and over. ${ }^{36}$ Gifts bear a somewhat lower tax rate, since the same tax rate is applied only to the net of tax amount. ${ }^{37}$ Cases can arise when the transfer tax rate is much higher. For instance, if a large amount is bequeathed out of earned income that has already been taxed at 39.6 per cent as personal income, this implies a cumulative tax rate as high as 73 per cent. If the delay between the saving and the inheritance is 30 years and the estate is left to a grandchild, the effective tax rate on the original pre-tax income rises to 96 per cent. ${ }^{38}$ Although it is recognised that the progressivity of the estate and gift tax is an important barrier to the inter-generational transfer of inherited wealth, many observers feel that, in combination with income tax, very high marginal tax rates may hinder saving and shift resources from productive to unproductive activities through estate-planning efforts. The impact of the estate tax on saving depends on the motivation for transfers. If bequests are unintentional, estate taxes will not affect saving by the donor. Even when bequests are intentional, though, evidence on the disincentives too may be weak (Gale and Slemrod, 2001), though one estimate suggests that the abolition of the estate tax might raise the size of estates by 10 per cent (Kopczuck and Slemrod, 2000). Moreover, estate taxes can be seen as horizontally inequitable, since they place a higher tax burden on those who wish to save than on those who wish to spend.

35. This lifetime credit is a tax deduction that ensures that this amount of money can be either given or bequeathed during a life.

36. Under current law, a surtax of 5 per cent applies to taxable estates between $\$ 10$ and $\$ 17$ million as the estate tax credit is phased-out.

37. Thus, for a gift that would be subject to a 37 per tax rate in an estate, the effective rate falls to 27 per cent.

38. The calculation is made on the following assumptions. The original income is taxed at 39.6 per cent, the asset is held as a corporate bond in conventional saving account with a nominal return of 7.6 per cent and inflation of 2 per cent. The size of the estate is over $\$ 1$ million and is left to a grandchild and, therefore, subject to a generation-skipping tax of 55 per cent. 
46. The new law that reduces estate tax rates and finally abolishes the tax in 2010 also changes the law with respect to capital gains and inheritances. On death, no capital gains taxes are payable when assets are transmitted to inheritors. Before its final abolition, the tax reference values for inherited assets is "stepped up" so that the recipients pay capital gains taxes only on the difference between the value of the asset when sold and the price on the date they inherited the assets. ${ }^{39}$ This gives a strong "lock-in" incentive for people to hold assets until death, reducing market liquidity and efficiency. However, once the estate tax is abolished in 2010, the capital gains tax that the inheritor pays eventually when the asset is sold will be determined by the acquisition cost of the asset of the legator. ${ }^{40}$ The new tax law does not abolish the gift tax; rather it sets the maximum rate at the same level as that of the income tax.

\section{Entrepreneurship: the gains from lower taxation}

47. There is a considerable body of evidence that the extent of entrepreneurship is increased by taxation. A high degree of entrepreneurship not only foster change but appears to be associated with higher saving and hence better economic performance (Box 5). Moreover, entrepreneurial households accounted for 39 per cent of household net worth in $1989,{ }^{41}$ with their wealth being held mainly in the form of business assets. Not only were these groups wealthier, they saved more - even after controlling for income level - and moved up the distribution of wealth during their lifetimes (Quadrini, 1999). Entrepreneurial activity, thus, appears to be linked to high saving, while lower taxation appears to improve the level of such activity. In this context, it is significant that much of the new tax cut will accrue to entrepreneurs, as a large part of income subject to the highest marginal tax rate accrues to this group. The Treasury estimated that 77 per cent of the marginal tax rate cuts in the House version of the new tax law would accrue to them.

\section{Box 5. Entrepreneurship and taxation: the empirical evidence}

Results based on cross-sectional studies that exploit the changes in marginal tax rates in the 1986 Tax Reform Act suggest that lower tax rates increase the probability of becoming an entrepreneur and the extent to which small companies expand (Gentry and Hubbard, 2000b). Other studies suggest that the size of an inheritance also affects the probability of starting a business and the likelihood of remaining an entrepreneur (Holtz-Eakin, Joulfaian and Rosen, 1994a and 1994b). Lower tax rates raise the reward to entrepreneurial activity and do indeed appear to increase the probability of becoming self-employed and expanding existing small companies. Capital gains taxes can also affect the supply and demand of funds for new enterprises. On the supply side, lower taxes increase the profitability of investing in new enterprises. On the demand side, lowering capital gains rates, if they are below income tax rates, are likely to increase the demand for funds as more managers leave employment and start businesses (Poterba, 1989). Empirical analysis of venture capital financing suggests that the demand effect predominates, as the sources of funds do not change when capital gains taxes change, despite some investors being exempt from this tax, indicating that more new venture capital operations is likely with lower capital gains tax rates

39. This is not the case for inter vivos gifts. The donor's cost of basis is carried over as the asset's basis. When the donee sells the asset, capital gains that accrued before the gift was made would be subject to capital gains taxation.

40. The new tax law provides for certain additions to the basis so that, in general, heirs of estates that are not currently subject to estate tax will not be subject to capital gains tax when carryover basis is implemented. Thus, for many estates, assets will still be stepped up at death, and there will still be an incentive to hold onto appreciated assets until death. In addition, taxpayers who inherit appreciated assets that are subject to capital gains tax, may still be induced to hold on to those assets. Therefore, it is not clear that lock-in under the new law will be markedly less than under the old law.

41. Many definitions of an entrepreneur are possible. One is that an entrepreneur is a person who owns at least $\$ 5000$ of business assets. On this basis, about 8.7 per cent of households are entrepreneurs (Gentry and Hubbard, 2000a). 
(Gompers and Lerner, 1999). ${ }^{1}$ Finally, reductions in tax rates appear to stimulate the growth of existing firms. Raising the tax price faced by an entrepreneur (i.e. one minus the marginal tax rate) by 10 per cent appears to increase the size of his enterprise by 8.4 per cent.

Taxation also affects the choice of organisational form, and firms that opt for the lower taxation regimes, in which companies are taxed only once ("S" corporations) grow faster than other companies. Such effects were noticed after the 1986 Tax Reform Act markedly changed the incentives for operating in these different forms, since income and capital gains fell relative to corporate taxation. Following the Act, there was a significant increase in the number of such "S" corporations. Moreover, as might be expected from the above links between saving and investment for entrepreneurs, corporations that changed status grew more rapidly than similar firms that did not (Carroll and Joulfaian, 1997). Policy changes that took effect in 1997 increased the attractiveness of these corporations, as they can now have 75 rather than 50 shareholders, and their attractiveness will be further increased by the planned reduction in personal income tax rates. However, non-resident aliens cannot be shareholders in " $\mathrm{S}$ " corporations, and this may restrict the supply of capital for these companies.

1. The elasticity of new venture capital investment with respect to the capital gains tax rate is similar across all classes of investors, independently of the tax status of the investor. This would not be the case if supply effects predominated, since pension funds are the largest supplier of venture capital and they are tax-exempt.

\section{Taxation of consumption}

48. The United States is the only OECD member country that does not apply a value-added tax, following the introduction of such a tax in Australia in July 2000. While states and local authorities rely mainly on sales taxes, the federal government collects mainly excises and tariffs. The major federal excise taxes, which in 1998 amounted to $\$ 118$ billion, are taxes on telecommunications, air travel, alcohol and tobacco, petrol and other fuels. Customs and import duties are a small share of indirect taxes. The most widespread federal tax is the telecommunications tax, paid by more than 94 per cent of households.

\section{Sales taxes: reform needed}

49. The state and local sales taxes lack a uniform sales tax base. Each taxing authority has its own exemption rules, its own definitions of products and services. As a result the Supreme Court has ruled that it is illegal for states to attempt to enforce the collection of sales taxes from enterprises that do not have a nexus in that state. The compliance costs would represent a barrier to interstate commerce, which would be unconstitutional. If tax bases were not so complex, then it might be possible to enforce out-of-state collection. Cross-border shopping, mail-order and e-commerce are the main sources of tax-base erosion. Consumers do not pay sales tax on goods ordered from out-of-state retailers by mail or the internet. ${ }^{42}$ States do have the option of taxing the use of a good rather than its purchase, but this is something that cannot be done easily, except in the case of goods that must be registered by the purchaser (e.g. cars and boats). It follows that residents of states with high sales taxes undertake more mail-order purchases - as well as electronic purchases - than those living in states with low sales taxes. Moreover such a system gives out-of-state retailers a competitive advantage over in-state retailers and deters mail-order and electronic commerce sellers from having a physical presence in a large number of states.

42. The revenue loss from untaxed interstate sales was estimated at over \$3 billion per year in 1997 (see Duncan and McLure, 1997), and about \$5 billion in total value of e-commerce escaped general sales taxes in 1998. For a more extensive description of the issues related to general sales taxes see Shaviro (1993). E-commerce is discussed in OECD $(2000 a)$. 
50. The states are moving to reduce the barriers to trade caused by differential sales tax regulations. Thirty-eight states are currently involved in the Streamlined Sales Tax Project, which is an effort by state governments, with input from local governments and the private sector, to simplify and modernise sales and use tax collection and administration. The Project's proposals will incorporate uniform definitions within tax bases, simplified audit and administrative procedures, and emerging technologies in order to substantially reduce the burden of tax collection. ${ }^{43}$

51. An ideal sales tax should not tax intermediate goods and services as this distorts the relative price of final goods, but sales taxes do not meet this criterion. Companies are, in many cases, able to claim exemption from the tax at the point of sale, but this provision does not work well. Ring (1999) estimated that 40 per cent of sales tax receipts are not paid by consumers. It is for this reason that there has been a general move away from sales taxes towards value-added taxes in the rest of the world. Moreover, in the United States, the proportion of sales tax paid by consumers is estimated by the same author to vary considerably across states. It is estimated by the same author that the highest proportion paid by consumers is in Virginia and Alabama (70 and 75 per cent, respectively), while the proportion is the lowest in Florida and Nevada (50 and 44 per cent, respectively).

52. The international experience of using a value-added tax that would serve both central and sub-central local government is limited. At one point, it was generally argued that a value-added tax was best administered just as a central government levy. A decentralised value-added tax was seen as involving high administrative and compliance costs and, moreover, might generate problems for cross-border trade between the states of a federation. Moreover, there was the further concern that, with no border controls, a conventional invoiced-based destination system of VAT would have difficulty in operating. Yet a destination system would be consistent with accountability, since it creates a direct link between the taxing authority and the local consumers that pay the tax. Destination-based systems have now been shown to work without border controls in the European Union. Moving to a joint federal state value-added tax would require the reconciliation of large number of conflicting interests that might be difficult to resolve. The Canadian experience suggests that a variety of arrangements are possible, with provinces choosing different mixes of sales and value-added taxes to supplement the federal tax. Compliance and administration costs would also have to be evaluated when considering such a tax.

\section{Environmental taxes}

53. Taxation can also be used to internalise costs that would otherwise not be taken into account by an individual in consuming a given product. Three product groups have traditionally attracted such taxes: hydrocarbons, alcohol and tobacco. It is not clear, though, whether the current taxes on these products are motivated more by the costs that their consumption places on others or by their relatively inelastic demands. The level of taxation on these products in the United States is much lower than in the rest of the OECD area.

54. Transportation is lightly taxed in the United States. Hydrocarbon taxes account for about 60 per cent of all taxes and fees levied on road transport, but there seems little environmental case for raising them all the way to European levels (Figure 14). Two principal externalities can be identified: the emission of pollutants that are harmful to health and the emission of carbon gases that generate global warming. In the United States, studies suggest that the external health costs of the first form of emission are around

43. Thirty-two states are voting participants in the project because their legislatures have enacted enabling legislation or their governors have issued executive orders or a similar authorisation. Six additional states are non-voting participants in the work of the project since they do not have the formal commitment of the state executive or legislative branches. 
10 cents per US gallon of gasoline (Krupnick et al., 1997). However, if the distance travelled in an area is high and the area is heavily populated, then costs may be as high as 60 cents per gallon (Small and Kazimi, 1995). High-pollution areas have generally chosen to limit motor vehicle emissions by special regulations governing allowable levels of additives (see OECD, 2001). There is, as yet, little agreement on the extent of the damage that might be caused by global warming. If the cost of damage is positive, then some taxation (or, less efficiently, equivalent regulation) would be justified.

Figure 14. Taxation of petrol : an international comparison 2000, US cents per US gallon

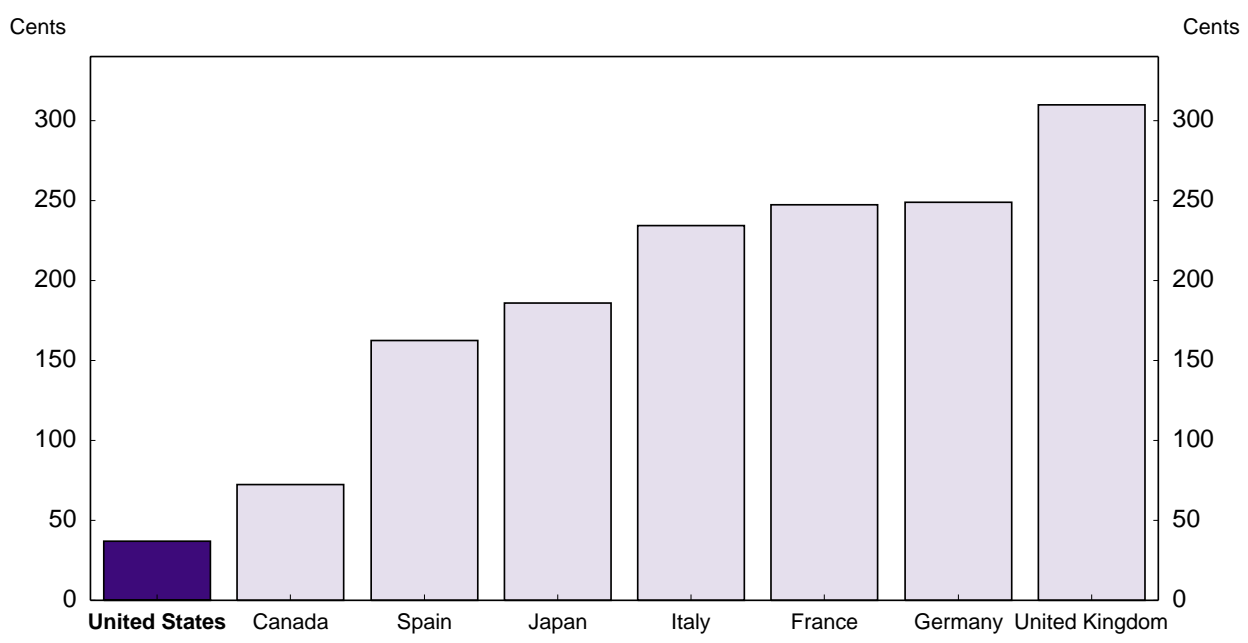

Source: International Energy Agency (2001).

55. Cars also are involved in accidents and cause congestion. A large part of accident costs is internalised through legal compensation for victims largely paid through compulsory insurance. The US government is generally not involved in the financing of insurance against road accidents, except through the programmes that cover old or poor people. The external cost of accidents appears to be around one cent per mile according to official estimates, an estimate that accords with academic estimates of 18 cents per gallon. ${ }^{44}$ Indeed, only 13 per cent of accident costs are not met by road users themselves (Table 12). Traffic congestion is also advanced as a reason for the taxation of petrol. Such a method of attempting to internalise the time lost by other drivers is, however, likely to be highly inefficient. It would impose large costs on people that travel at times or in places when there is no congestion. Road pricing would be the least-distorting solution to the problem of congestion.

44. The total cost of accidents was estimated by Small and Goméz Ibánez (1999) to be 18 cents per mile. With an average fuel consumption of 20 miles per gallon, this translates into a cost of accidents of 360 cents per gallon. A higher tax would improve fuel efficiency and reduce miles travelled by less — and accident cost is related to miles travelled - so this cost has to be halved (Parry, 2000). Moreover, the legal system is likely to ensure most of the cost of accidents is borne by the car driver. Assuming, as the authors do, that 90 per cent of accident costs are internalised, then the accident externality cost is 18 cents per gallon. 
ECO/WKP(2001)39

Table 12. Taxes and fees on motor vehicles compared to costs generated by motor vehicles 2000, \$ million

\begin{tabular}{|c|c|c|c|}
\hline Motor fuel & 71503 & Return on capital invested in roads & 48548 \\
\hline Tolls & 6661 & Maintenance & 23046 \\
\hline Tyre tax & 439 & Traffic services & 6326 \\
\hline Weight distance tax & 734 & Administration & 10660 \\
\hline Registration and title fees & 25217 & Law enforcement & 14403 \\
\hline Vehicle excise tax & 2347 & Pollution & 40443 \\
\hline Drivers licence & 1109 & Noise & 4336 \\
\hline Fines & 180 & External accident costs & 45246 \\
\hline Other fees & 5089 & & \\
\hline Total & 113279 & & 193008 \\
\hline \multicolumn{4}{|l|}{ Memorandum items: } \\
\hline Congestion costs & 61761 & & \\
\hline Accident costs borne by users & 294460 & & \\
\hline Global warming costs & Unquantifiable & & \\
\hline Capital expenditure on roads & 53730 & & \\
\hline Federal gasoline tax & 18.3 cents per gallon & & \\
\hline Federal diesel tax & 24.3 cents per gallon & & \\
\hline State gasoline tax & 18.7 cents per gallon & & \\
\hline
\end{tabular}

Note: Return on capital for road system based on the replacement capital stock value estimated by the Bureau of Economic Analysis multiplied by the yield on 30 year indexed government securities.

Source: Federal Highways Administration (2000).

56. Overall, the previous estimates suggest that taxes on petrol are on the low side in the United States. After including a number of other forms of taxation and levies on road-users, the total revenue raised from road-users amounted to $\$ 113$ billion in 2000 . Recognising for the direct cost of capital invested in roads, maintenance and other related costs of running the road system, the revenue raised from road-users slightly exceeds the direct costs of the system. However, once external costs (such as pollution, noise and accident costs) are allowed for, an increase in fuel taxes of around 40 cents per gallon would be justified. No adjustment has been made for the costs of global warming, as these cannot be quantified as yet with certainty. A full analysis would likely show that much of this increase should fall on trucks, in view of the damage they cause to infrastructure.

57. Environmental concerns linked to global warming might suggest taxing of other fossil fuels in accordance with their carbon dioxide emissions would raise considerable revenue. The use of gasoline and distillates in road transport accounts for only 26 per cent of carbon emissions in the United States (Table 13). The remaining three-quarters are not taxed. For example, the total yield from a tax to $\$ 100$ per tonne of carbon would have been slightly more than $\$ 110$ billion in $1999, \$ 55$ billion coming from coal and the remainder spit between natural gas and other forms of petroleum use that are currently not taxed. By comparison, the yield of the federal corporate income tax was $\$ 184$ billion in the same year. 
Table 13. Carbon dioxide emissions by fuel and current tax status

\begin{tabular}{|c|c|c|c|c|}
\hline & 1990 & 1995 & 1999 & 1999 \\
\hline & $\begin{array}{r}\text { Millior } \\
\text { carbc }\end{array}$ & $\begin{array}{l}\text { metric tor } \\
\text { n equivale }\end{array}$ & & $\begin{array}{l}\text { Per cent } \\
\text { of total }\end{array}$ \\
\hline Carbon-emitting fuels currently taxed & 337 & 364 & 399 & 26 \\
\hline Gasoline used for transportation & 261 & 279 & 299 & 19 \\
\hline Distillates in transport & 76 & 85 & 100 & 7 \\
\hline Carbon-emitting fuels currently not taxed & 1013 & 1071 & 113 & 74 \\
\hline Coal & 484 & 510 & 549 & 36 \\
\hline Natural gas & 273 & 314 & 312 & 20 \\
\hline All other uses of petroleum & 255 & 233 & 251 & 16 \\
\hline Coverage differences and other sources & 1 & 14 & 26 & 2 \\
\hline Total estimated carbon emissions & 1350 & 1435 & 153 & 100 \\
\hline
\end{tabular}

Source: Energy Information Administration.

\section{Tobacco}

58. Excise taxes are also generally levied on tobacco and alcohol. These taxes could be "optimal" since the demand for these goods is inelastic. Tobacco and alcohol are also likely to impose external costs on society in that both are addictive and have health effects both on the consumer and, for tobacco, on the rest of society. If, however, addicts are rational, that is to say that they foresee the adverse consequences on their own health and discount them over time in order to decide their smoking or drinking habits, then the evidence from the United States suggests that the optimal tax is low (Manning et al., 1991). However, Gruber and Köszegi (2000) have suggested that there is evidence that addicts are not rational and hence a higher tax would force them to take into account some of the costs they impose on themselves. ${ }^{45}$

\section{Telecommunications}

59. Another area that is subject to excise taxation is telecommunications. Not only is there an excise on telecommunication, but there are also a number of fees for landline services that are determined by the Federal Communications Commission (FCC). These taxes (including a 3 per cent excise tax) and fees are used directly to fund services in the telecommunications area. Congress has introduced a further charge on telephones to fund Internet access for schools and libraries. The demand for long-distance calls is price-elastic, whereas the demand for the rental of a telephone line is inelastic. Standard public finance theory suggests switching the charge to the rental of the line, thereby reducing the extent of loss in consumer welfare, but it was thought that keeping line rentals cheap helped the poor to have telephones. In practice, subsequent research found that even lower income groups would benefit from the rebalancing of

45. Addicts appear to discount future events at much higher interest rates than nearby events, thereby generating time-inconsistent behaviour. Such a proposition also finds support from experimental studies. There is room for government intervention not just to correct an externality, but also to ensure that smokers correctly value the internal costs of their own decisions on their health and that, according to Gruber and Köszegi (2000), amount to \$27 per package of cigarettes (on the basis that each cigarette smoked reduces life expectancy by 7 minutes). 
tariffs. Mobile telephony is also subject to considerable taxation. Most of these taxes are determined locally. The median tax rate across states is 14.5 per cent, and there are peaks in California ${ }^{46}$ and Florida of 25.5 per cent. However, the loss is less than for the long-distance access charges as the demand elasticity for mobile services is less than that for landline services, though this may be changing as mobile telephone penetration increases (Hausman, 1999).

\section{Compliance and administration}

60. The costs of administering the tax system are estimated to be high and rapidly growing and to fall mainly on the private sector, as in other countries. This burden can be divided into several components: the value of the time taken to fill out forms and keep appropriate records and the out-of-pocket costs incurred by taxpayers. ${ }^{47}$ In FY 2000, the cost of this compliance effort is estimated to have amounted to $\$ 167$ billion, fully 133/4 per cent of corporate and personal federal income taxation, ${ }^{48}$ over 20 times as much as the annual cost of running the IRS. Indeed, the work represented to fill in tax forms represented 82 per cent of the time burden placed on the private sector by the federal government through information collection. The corporate tax does seem particularly expensive in terms of compliance, with costs perhaps as high as half the yield of the tax. The distinction between items that are a current expenditure and those that are capital expenditures is an area that generates much litigation. Many taxpayers used professional tax preparers (38 per cent for those filing the simplified form and 64 per cent amongst those who used the more complicated forms (Gale and Holtzblatt, 2000)). Even professional tax preparers make interpretation errors in complex areas (Caplin, 1998). Technology may be helping to reduce compliance costs with 39.5 million people having filed their 2000 tax returns electronically by April 2001, an increase of 13 per cent on the previous year. Almost one-third of the returns are now filed this way, the bulk originating from professional preparers. However, the number of people filing directly from their own PC has been soaring, reaching 6.6 million in 2001, up 35 per cent from the previous year. The IRS aims to have 80 per cent of all tax and information returns filed electronically by 2007.

\section{Improving the yield of taxation}

61. Despite the high compliance rate, there has been evidence that a significant amount of tax was not collected. Until 1988, the Internal Revenue Service (IRS) conducted random audits of a small sample of taxpayers. For subsequent years, projections were made on the basis of such checks. In 1992, the latest year available, it was estimated that about 18 per cent of potential revenues from corporate and individual

46. In addition to the normal state, county and local sales tax, a mobile-phone user pays taxes levied by the California Public Utilities Commission for universal service, emergency telephone services, a high-cost-areas fund, a tele-connect fund and a hearing-impaired fund. Finally, there is state utility tax and the federal excise tax to be paid.

47. The benchmark estimates of these compliance costs are now very dated, as they are based on a survey conducted in 1983. It concluded that the time spent on compliance amounted to 1.6 billion hours for individuals and 2.7 billion hours for businesses and partnerships. These survey results have been used to calibrate a model based on the length of tax forms, providing the basis for official estimates of the time required to comply with the tax system. By 2000, the total time spent on compliance amounted to an estimated 6.1 billion hours, fully 2.5 per cent of total hours worked in the United States. The total had increased by over 15 per cent since 1997 (Office of Management and Budget, 2001). Based on official estimates of the value of this time.

48. These estimates are based on Table 3 of Gale (2001). It uses the estimate of compliance estimates by Hall and the post-tax wage for individuals and hourly professional labour cost for corporations. The hourly costs have been updated to 2000 using the movement of business sector wages and the growth in compliance time shown by the OMB (Keating, 2001). 
income taxes were not paid. ${ }^{49}$ Not surprisingly, compliance rates are lowest for income that does not have taxes withheld at source and is not reported separately to the IRS. Small businessmen and farmers were estimated to have underreported about 30 per cent of their income in 1992. Since then, no further random samples have been undertaken due to the unpopularity of these audits amongst the vast majority of filers whose mistakes, if any, were inadvertent. Congress has included funding for specific compliance initiatives designed to improve tax yields through programmes such as the one that seeks to improve the collection of delinquent taxes (General Accounting Office, 1994).

62. The progressive move to electronic filing should free more resources within the IRS to be devoted to reducing tax evasion. This would help make up for the 31 per cent cut in IRS permanent staff that has occurred since 1988, while the number of returns filled has gone up rapidly (e.g. individual return filing has risen by 34 per cent). Changes in collection and audit procedures by the 1998 IRS Reform Act have led to reduced collection activity by the IRS, as it revised procedures to comply with the law, and to fewer tax audits. The staff of the IRS has been oriented towards improving the way it deals with individual taxpayers with the share of individual income tax returns audited falling from 1.3 to 0.5 per cent between 1997 and 2000. At the same time, the use of information technology to cross-check declarations from different sources has been increased substantially. The progressive move to electronic filing should permit a further improvement in cross-checking, once the appropriate investments have been made.

\section{Assessment of past changes and recommendations for action}

63. In aggregate, the United States is a low-tax economy. There are only a few OECD Member countries with a lower tax take, despite the large number of US taxing authorities. The rates on individual items are also at the low end of the scale used in other OECD Member countries, with the exception of property taxation. The highest marginal income tax rate varies between 39.6 per cent and 46.8 per cent in Massachusetts. The average top rate is around 43 per cent, given full deductibility of state and local taxes. Moreover, this tax rate does not come into effect until a household has an annual income of around $\$ 300000$, an extremely high level. Social insurance taxes are also low, reflecting a policy choice that emphasises private provision of health and pension services for middle- and higher- income groups. General sales taxes are also low, with an average rate of just 5.2 per cent, but fall on intermediate transactions to a certain extent, distorting the organisation of production. This is in contrast to other OECD countries that have moved to a system based on the taxation of final consumption alone using a VAT.

64. The 2001 tax changes will reduce taxes by 11/4 percentage points of GDP when they are finally implemented in 2010. The tax changes and the timetable for implementation are outlined in detail in OECD (2001), where the impact on the budget is also discussed. The changes introduced in the act do not amount to a full-scale tax reform. Rather they are more designed to ensure that the overall tax ratio does not remain at its recent high level permanently. The cuts do move, nonetheless, in a direction that is likely to improve efficiency. The reductions in higher marginal tax rates, the ending of the phase-outs on the personal exemption and itemised deductions and ending of estate tax are projected to account for 51 per cent of the total tax cuts by 2010. A further 4 per cent of the total is devoted to expanding tax-favoured saving plans. The remainder is made in a way that is essentially distributed on a flat-rate basis to all taxpayers and so has little incentive effect. In some respects, the tax act leaves an amount of unfinished business and uncertainty. The expiration of the cuts in 2010 is an anomaly that was generated by

49. The tax gap measures the difference between taxes that should have been paid on income earned in legal activities and taxes that were paid on that income in a voluntary and timely manner. The gap stems from taxpayers who do not report all of their income, or do not remit all of their reported taxes, or who claim excess deductions, or do not file a tax return, but it does not include revenues lost from the failure to tax criminal activities (Gale and Holtzblatt, 2000). 
procedural problems. Putting the changes onto a permanent basis should be a priority. Equally, a few small measures expire at an even earlier date and should also be prolonged, as in some cases they refer to expenditure that has to be planned over a long period (such as education). The tax cut has pre-empted most of the long run on budget surplus and so makes future tax reform that much more difficult. Nonetheless, further revenue-neutral tax reform could well further improve economic performance and so should be an important objective for the Administration.

65. Although there is a low level of taxation, the current system is not designed in a way that minimises the excess burden of taxation. The most noticeable inefficiencies come in the area of capital income taxation. There is a notable tension between not taxing some forms of capital income and imposing high tax rates elsewhere. Income and most capital gains from owner-occupied housing are tax-free, and there are several forms of savings accounts where income is not taxed. Almost half of personal-sector assets are held in forms that ensure that they are exempt from personal income taxation. Moreover, capital gains are taxed at a lower rate than ordinary income. In contrast, corporate dividends are taxed heavily, with a combined rate that approaches 62 per cent in high-income tax states. The combined rate of tax is lower for retained earnings and even lower for interest, giving rise to considerable possible bias in business financing decisions. Legislators have recognised that such taxation may be an excessive price to pay for the advantage of limited liability and so may act as a deterrent to entrepreneurial activity. Congress has allowed corporate structures that do not face double taxation on dividends, and their numbers have risen to become a majority of all companies. Any taxation of capital income, however, represents a significant departure from the neutrality of taxation over time, favouring present over future consumption. In the past, a number of legislative proposals have been designed to reduce the burden on saving, through the replacement of an income by consumption tax. While in many ways this would be the best approach, it is one that that would represent a major change in a tax system that has evolved gradually and, therefore, is unlikely to be undertaken.

66. A more likely alternative direction for change would be to reform business taxation by lowering corporation tax, not taxing dividends and reducing capital gains taxation at the individual level. This corresponds to the limiting case of the relief systems introduced in several OECD countries in recent years. At the same time the various tax breaks for companies could be phased out. The economy would be likely to benefit from such a process since the cost of capital is determined primarily by domestic factors, as US internal developments exert a large influence on the determination of interest rates in global capital markets. Such a system would eliminate the difference between the cost of capital for new-equity and retained-earnings finance; it would reduce the bias in favour of debt finance and non-corporate business structures. Lower capital gains taxation would likely stimulate entrepreneurial activity. Moreover, a rise in the post-tax return to savings would reduce the bias in favour of housing. Nonetheless, a financing bias would still exist in view of the number of tax-exempt methods of holding assets. The personal income tax system could also be moved towards a consumption-based system by extending the number of tax-favoured saving schemes. Another possible direction for reform would be to introduce different schedules for labour and capital income. Many countries have such systems and usually tax capital income at a lower rate than labour income. Nordic countries have been particular advocates of this system, with Iceland having a flat capital income tax rate of only 10 per cent.

67. Substantial efficiency gains could be also made in the personal income tax system through lowering marginal tax rates. The new tax law passed by Congress recognises the possibility of such gains and is oriented to reducing marginal tax rates and lowering capital income taxation by eliminating the estate and gift tax. However, the recent tax reductions and spending increases have eliminated most of the scope for further reductions in the budget surplus over the next decade - especially as it makes no allowance for the continuation of the programme in the last year of the current budget window. Further reform would need to be part of a revenue-neutral package. There is considerable scope for such a plan. The list of tax expenditures is long, and reductions could focus on those that introduce the most 
pronounced distortions. Mortgage interest payments and the deductibility of state and local income and property taxes could be called into question. The value of such deductions increases with income and results in markedly unequal transfers of resources across the nation. The former distorts capital allocation away from business assets. Another large revenue loss stems from the non-taxation of employer-provided health-care insurance premiums. It seems anomalous that a person with low income and perhaps no health-insurance coverage receives no help from the federal government while a high-tax worker with employer-provided insurance benefits from substantial subsidies. A number of proposals have been made to end this anomaly by granting tax credits to low earners. (A fuller treatment of the issue of financing health care and reducing the number without insurance cover can be found in the two previous Surveys). However, a number of tax expenditures are justifiable such as those for saving and education spending.

68. At the same time as the base was widened and marginal rates reduced, the Administration has indicated that it will be working towards substantial changes in the Alternative Minimum Tax (AMT). This parallel tax system was designed to stop the wealthy paying no tax. In practice, just as many of the wealthy do not pay tax today as 20 years ago. However, they pay no tax not because of excessive use of legal tax shelters, but in the main because they have invested in municipal tax-exempt bonds or have had exceptionally large medical expenses or losses not covered by insurance - both of which reduce their ability to pay income tax. In any case, if the tax base were to be broadened by ending, for instance, the deduction for state and local income taxes, thereby enabling marginal tax rates to be lowered, the rate under the normal system and the AMT could be brought together. Indeed, the relative simplicity of the AMT structure has much in its favour, in that it is based on a single deduction and has only two rates.

69. More generally, a reduction in the number of allowances would allow the multiplicity of marginal effective tax rates for people with the same taxable income to be reduced. Such differences are generated by phase-outs that depend on their personal circumstances, thereby adding to complexity and, arguably, generating a lack of horizontal equity. The sheer number of allowances also adds to complexity, as each tends to have its own particular definitions of concepts that are also used elsewhere in the tax code. Thus, there are nine different definitions of a child, educational expenditure is defined in four different ways, and there is a whole range of different education allowances and tax-favoured saving accounts. There has, though, to be some doubt about whether reducing the extent of tax expenditures is a realistic goal. The FY 2002 tax legislation contains many new tax expenditures, though some (such as the raising of ceilings on retirement saving plans) bring the income tax system even closer to a consumption tax base. The new energy policy of the Administration contains further tax expenditures.

70. A broadening of the tax base would allow an expansion of the Earned Income Tax Credit. To reward work, the EITC is set in a way that the credit is phased in smoothly as earnings increase. However, the current phase-in range extends to an income that is below the yearly minimum-wage income for a full-time job. As well, the phase-out of the benefit starts at below the poverty line for a family of four and raises the effective marginal tax rate low-income households. Extending the EITC ceilings towards the annual minimum wage could draw many more workers into the labour force and reduce welfare payments. Nonetheless, there would be a risk that, if the rate at which the credit is phased-out were raised, incentives to look for better-paid jobs would be lowered. It seems likely, nevertheless, that the expansion of the credit would draw more people into employment. Policy makers would have to weigh this gain against the cost imposed elsewhere in the economy, taking into account the extent to which gains for low-income workers are valued more highly than losses for high-income workers.

71. The current system of state and local sales taxes appears to be archaic. They are mainly levied on goods, though some services are taxed. The bases and definitions vary from state to state and even locality to locality. The degree of complexity is such that, in the opinion of the Supreme Court, they constitute a barrier to inter-state commerce, and so an out-of-state business cannot be obliged to pay the tax when selling to an in-state client. Moreover, about 40 per cent of the tax does not fall on consumers, thereby 
violating a basic principle of tax neutrality. States are moving to harmonise their tax bases under the threat of erosion of their tax base stemming from e-commerce, and further progress is needed in this area. It could come through the adoption of a value-added tax rather than a sales tax, with a uniform national structure. Such a tax might be difficult to agree. However, states have been willing to use federal tax bases for the taxation of income and estates. One path might be to introduce a low federal value-added tax that could also be used to finance part of any reform to the taxation of business, capital gains taxation and income that is saved. States would then be able to add their own VAT to replace a sales tax, while some might choose to retain a sales tax.

72. Both the federal government and states have a large number of specific excise taxes, mainly set at low rates. Specific taxes are less important than in other countries as a result of the low rates charged on alcohol, tobacco and gasoline. A comparison of external costs and current tax rates suggests that there is justification for increasing the tax on tobacco substantially. In this case, there seems to be evidence that smokers do not internalise the full costs of their addiction, valuing the future much less than is justified in a normal economic framework.

73. There is a case based on externalities for some increase in the tax on petrol. Such taxes should be set at a level that internalises the external and use-related costs of using the fuel. The health costs of car pollution, noise, the external cost of accidents and road-use costs appear to be around 80 cents per gallon. The current tax levels is 38 cents per gallon, suggesting that gasoline taxes should be increased by about 40 cents per gallon. It is only if gasoline taxes were used as a way to reduce traffic congestion that a greater increase in major taxation could be justified. This however would be a very inefficient way of achieving this goal, costing three times as much as peak-hour road pricing - a form of taxation that should be considered when technically feasible. In effect using gasoline taxes to reduce congestion imposes costs for travel in non-congested or at off-peak times. Scope exists for taxing other uses of carbon, in view of the concern about the warming effect of a carbon dioxide emissions. For example, a tax of $\$ 100$ per tonne of carbon might raise $\$ 100$ billion of revenue. As yet, costs benefit studies are uncertain and should be improved.

74. Overall, there appears to be considerable scope for improving the overall efficiency with which taxation is raised. The current package of tax cuts legislated this spring contains many elements that will improve efficiency. Further progress could take two routes (Box 6). One is just to focus on anomalies in the current income tax system with the objective of simplifying the system. But it would seem that a more fundamental reform is called for. The taxation of businesses, capital gains and capital income more generally should be lowered relative to that of income that is consumed. Such a move would be likely to initially increase the income share of the richest groups in US society but should eventually also increase output and real wages more generally.

\section{Box 6. Recommendations for tax policy}

\section{Move the tax system more to one based on the taxation of consumption}

- Increase the limits for contributions into tax-free saving accounts

- Reform company taxation through lowering the tax rate, exempting dividends from further taxation, updating depreciation rates and reducing tax deductions for companies.

- Lowering capital gains taxation

\section{Simplify the personal income tax system}

- Ensure consistency of definitions used in allowances across the board

- Revise taxation of Social Security benefits to bring them in line with private pensions 
- Reduce the number of phase-outs used in the income tax system

\section{Widen the base of personal income taxation}

- Phase out mortgage tax and state and local government tax deductions

- Work towards substantial changes in the Alternative Minimum Tax

- Lower the higher marginal rates of taxation

\section{Reform indirect taxation}

- Encourage states to move towards a uniform sales tax base

- Consider the introduction of a federal value-added tax

- Consider higher taxation of carbon-based products

\section{Improve the position of low-income employees}

- Extend the Earned Income Tax Credit

\section{Administration}

- Continue progress towards the 80 per cent target for electronic tax filing

- Used freed resources to improve cross-matching of different income data sources

- Reduce fraud in the Earned Income Tax Credit programme 
ECO/WKP(2001)39

\section{BIBLIOGRAPHY}

Alesina, Alberto, Rafael Di Tella and Robert MacCulloch (2001),

"Inequality and Happiness: Are Europeans and Americans Different?", National Bureau of Economic

Research Working Paper No. 8198, April.

Auerbach, Alan J. (1997),

"The Future of Fundamental Tax Reform", American Economic Review, 82, 2, May.

Balkovic, Brian (2001),

“Individual High-Income Tax Returns for 1998”, Statistics of Income Bulletin, Winter 2000-2001.

Bassanini, Andrea, Jørn H. Rasmussen, and Stefano Scarpetta (1999),

"The Economic Effects of Employment-Conditional Income Support Schemes for the Low-Paid", OECD

Economics Department Working Papers 224, October.

Bassanini, Andrea, Stefano Scarpetta and Philip Hemmings (2001),

"Economic Growth: The Role of Policies and Institutions. Panel Data Evidence from OECD Countries", OECD Economics Department Working Papers No. 283, January.

Boskin, Michael J. (ed.) (1996),

Frontiers for Tax Reform, Hoover Institution Press, Stanford.

Brazell, David W. and James B. Mackie (2000),

"Depreciation Lives and Methods: Current Issues in the U.S. Capital Cost Recovery System", National

Tax Journal, 53(3), Part I, September.

Bruce, David and Douglas Holtz-Eakin (2001),

"Will a Consumption Tax Kill the Housing Market?", in Kevin A. Hassett and R. Glenn Hubbard (eds.), Transition Costs of Fundamental Tax Reform, American Enterprise Institute Press, Washington, D.C.

Bull, Nicholas, Janet Holtzblatt, James R. Nunn, and Robert Rebelein (1999),

"Defining and Measuring Marriage Penalties and Bonuses", Office of Tax Analysis Working Paper 82, US Department of the Treasury.

Burkhauser, Richard V., Douglas Holtz-Eakin, and Stephen E. Rhody (1997),

"Labor Earnings Mobility and Inequality in the United States and Germany During the Growth Years of the 1980s", National Bureau of Economic Research Working Paper No. 5988, April.

Caplin, Joan (1998),

"Six Mistakes Even the Tax Loss Make", Money, March.

Carroll, Robert and David J. Joulfaian (1997),

"Taxes and Corporate Choice of Organisational Form", Office of Tax Analysis Working Paper 73,

US Department of the Treasury.

Congressional Budget Office (1997),

Comparing Income and Consumption Tax Bases, Congressional Budget Office, July. 


\section{ECO/WKP(2001)39}

Contos, George and Ellen Legel (2000),

“Corporation Income Tax Returns, 1997”, Statistics of Income Bulletin, Internal Revenue Service, March.

Cronin, Julie-Anne (1999),

"US Treasury Distributional Analysis Methodology", Office of Tax Analysis Working Paper No. 85.

Desai, Mihir A. and James R. Hines (2000),

"The Uneasy Marriage of Export Incentives and the Income Tax", National Bureau of Economic

Research Working Paper 8009, November.

Duncan, Harley T. and Charles E. McLure, Jr. (1997),

"Tax Administration in the United States of America: A Decentralized System", Bulletin of the

International Bureau of Fiscal Documentation, February.

Edwards, Chris (2001),

"Simplifying Federal Taxes: The Advantages of Consumption-Based Taxation", Policy Brief 416, Cato Institute, Washington, D.C., October.

Eissa, Nada and Hillary W. Hoynes (1999),

"Good News for Low-Income Families? Tax-Transfer Schemes and Marriage", unpublished.

Engen, Eric M. and Jonathan Skinner (1996),

"Taxation and Economic Growth", National Tax Journal, 49(4), December.

Enrich, Peter D. (1998),

"The rise -- and perhaps the fall of business tax incentives", in David Brunori (ed.), The Future of State

Taxation, The Urban Institute Press, Washington, D.C.

Federal Highways Administration (2000),

Addendum to the 1997 Federal Highway Cost Allocation Study Final Report, May Washington D.C

Feldstein, Martin and Daniel Feenberg (1995),

"The Taxation of Two Earner Households", National Bureau of Economic Research Working

Paper 5155, June.

Feldstein, Martin and Jeffery B. Liebman (2001),

"Social Security", National Bureau of Economic Research Working Paper No. 8451, September.

Forster, Michael F. (2000),

"Trends and Driving Factors in Income Distribution and Poverty in the OECD Area", OECD Labour Market and Social Policy Occasional Paper No. 42.

Gale, William G. (2001),

"Testimony Before the Subcommittee on Oversight of the House Committee on Ways and Means", Washington, D.C.

Gale, William G. and Janet Holtzblatt (2000),

"The Role of Administrative Factors in Tax Reform: Simplicity, Compliance, and Administration", in George R. Zodrow and Peter Mieszkowski (eds.), United States Tax Reform in the Twenty-First Century, Cambridge University Press, forthcoming.

Gale, William G. and Joel B. Slemrod (2001),

"Rethinking the Estate and Gift Tax: Overview", The Brookings Institution, xerox. 
General Accounting Office (1994),

Tax Gap - Many Actions Taken, But a Cohesive Compliance Strategy Needed, GAO/GGD-94-123, May.

Gentry, William M. and R. Glenn Hubbard (2000a),

"Entrepreneurship and Household Saving", National Bureau of Economic Research Working Paper 7894, September.

Gentry, William M. and R. Glenn Hubbard (2000b),

"Tax Policy and Entrepreneurial Entry", American Economic Review, 90, 2, May.

Gompers, Paul A. and Josh Lerner (1999),

"What Drives Venture Capital Fundraising", National Bureau of Economic Research Working

Paper 6906, January.

Goolsbee, Austan and Edward L. Maydew (1998),

"Coveting Thy Neighbour's Manufacturing: The Dilemma of State Income Apportionment", National

Bureau of Economic Research Working Paper No. 6614, January.

Gravelle, Jane G. (1995),

"The Corporate Income Tax: Economic Issues and Policy Options", National Tax Journal, Vol. 48, No. 2.

Gruber, Jon and Botond Köszegi (2000),

"Is Addiction 'Rational'? Theory and Evidence", National Bureau of Economic Research Working

Paper 7507, January.

Gruber, Jon and Emmanuel Saez (2000),

"The Elasticity of Taxable Income: Evidence and Implications", National Bureau of Economic Research Working Paper 7512.

Gyourko, Joseph and Todd Sinai (2001),

"The Spatial Distribution of Housing-Related Tax Benefits in the United States", National Bureau of Economic Research Working Paper 8165.

Hall, Brian J. and Kevin J. Murphy (2000),

"Stock Options for Undiversified Executives", National Bureau of Economic Research Working

Paper 8052, December.

Hassett, Kevin A. and R. Glenn Hubbard (2001),

Transition Costs of Fundamental Tax Reform, American Enterprise Press, Washington, D.C.

Hausman, Jerry (1999),

"Efficiency Effects on the U.S. Economy from Wireless Taxation", National Bureau of Economic

Research Working Paper 7281.

Heady, Christopher (1996),

"Optimal Taxation as a Guide to Tax Policy", in Michael P. Devereux (ed.), The Economies of Tax Policy.

Holtz-Eakin, Douglas, David Joulfaian and Harvey S. Rosen (1994a),

"Sticking it Out: Entrepreneurial Survival and Liquidity Constraints", Journal of Political Economy, 102, 1 , February. 


\section{ECO/WKP(2001)39}

Holtz-Eakin, Douglas, David Joulfaian and Harvey S. Rosen (1994b),

"Entrepreneurial Decisions and Liquidity Constraints", RAND Journal of Economics, $25,2$.

Hoppe, Robert A. (ed.) (2001),

"Structural and Financial Characteristics of U.S. Farms: 2001 Family Farm Report", Agriculture

Information Bulletin No. 768, US Department of Agriculture, Economic Research Service, May.

Hotz, V. Joseph and J.Karl Scholz (2000),

"Not Perfect But Still Pretty Good: The EITC and Other Policies to Support the US Low-wage Labor Market", unpublished paper written for the OECD.

Hotz, V. Joseph and J.Karl Scholz (2001),

"The Earned Income Tax Credit", National Bureau of Economic Research, Working Paper 8078, January.

Joint Committee on Taxation (2001a),

"Overview of Present Law and Economic Analysis of Marginal Tax Rates", JCX-6-01, US Congress, Washington, D.C., 6 March.

Joint Committee on Taxation (2001b),

"Overview of Present Law and Selected Proposals Regarding the Federal Income Taxation of Small

Businesses and Agriculture", JCX-19-01, US Congress, Washington, D.C., 27 March.

Jorgenson, Dale W. and Kun-Young Yun (2001),

"Lifting the Burden: Fundamental Tax Reform and U.S. Economic Growth", Paper presented to the

GTAP Annual Conference, Purdue University, May.

Judd, Kenneth L. (2001),

"The Impact of Tax Reform in Modern Dynamic Economies", in Kevin A. Hassett and

R. Glenn Hubbard (eds.) (2001), Transition Costs of Fundamental Tax Reform, American Enterprise Institute Press, Washington, D.C.

Keating, David L. (2001),

"A Treasury Trend: The Rise in Complexity", Policy Paper 105, National Taxpayers Union, Washington, D.C.

Kennickell, Arthur B., Martha Starr-McCluer and Brian J. Surette (2000),

"Recent Changes in US Family Finances: Results from the 1998 Survey of Consumer Finances", Federal Reserve Bulletin, January.

Kohl, Richard and Paul O'Brien (1998),

"The Macroeconomics of Ageing, Pensions and Savings: A Survey", OECD Economics Department Working Paper No. 200.

Kopczuk, Wojciech and Joel Slemrod (2000),

"The Impact of the Estate Tax on the Wealth, Accumulation and Avoidance Behaviour of Donors", National Bureau of Economic Research Working Paper 7960, October.

Krupnick, Alan J., Robert D. Rowe and Carolyn M. Lang (1997),

"Transportation and Air Pollution: The Environmental Damages", in David I. Greene and Mark A. Delucchi (1997), The Full Cost and Benefits of Transportation: Contributions to Theory, Method and Measurement, Springer, New York. 
Laibson, David I. (1996),

"Hyperbolic Discount Functions, Undersaving, and Savings Policy", National Bureau of Economic

Research, Working Paper No. 5635.

Leibfritz, Willi, John Thornton and Alexandra Bibbe (1997),

Taxation and Economic Performance, OECD Working Paper No. 176, June.

Manning, Willard G., Emmert B. Keeler, Joseph P. Newhouse, Elizabeth M. Sloss and Jeffrey Wasserman (1991),

The Costs of Poor Health Habits, Harvard University Press, Cambridge, Massachusetts.

McLure, Charles (1980),

"The State Corporate Income Tax: Lambs in Wolves' Clothing", from The Economics of Taxation,

H. Aaron and M. Boskin (eds.), Brookings, Washington, D.C.

Meyer, Bruce and Dan T. Rosenbaum (2000),

"Making Single Mothers Work: Recent Tax and Welfare Policies and its Effects", National Bureau of Economic Research Paper 7491, January.

Mitrusi, Andrew and James Poterba (2000),

"The Distribution of Payroll and Income Tax Burdens, 1979-1999”, National Bureau of Economic

Research Working Paper 7707, May

OECD (1999),

Economic Survey of the United States, Paris.

OECD (2000),

Economic Surveys, United States, Paris, May.

OECD (2001),

Economic Surveys, United States, Paris, November.

Office of Management and Budget (2001),

Information Collection Budget of the Federal Government for FY 1999 and FY 2000, Washington, D.C.

Parry, Ian W.H. (2000),

"Comparing the Marginal Excess Burden of Labour, Gasoline, Cigarette and Alcohol Taxes", Resources for the Future, Discussion Paper 00-33.

Petska, Toru, Mike Studler, and Ryan Petska (2000),

"Further Examination of the Distribution of Individual Income and Taxes Using a Consistent and

Comprehensive Measure of Income", Statistics of Income Overview, Research Paper, Internal Revenue Service, March.

Poterba, James (1989),

"Venture Capital and Capital Gains Taxation", in L. Summers (ed.), Tax Policy and the Economy, MIT Press, Cambridge, Massachusetts.

Poterba, James M., Steven F. Venti, and David Wise (1997), "Personal Retirement Saving Programs and Asset Accumulation: Reconciling the Evidence", National Bureau of Economic Research Working Paper No. 5599, January 


\section{ECO/WKP(2001)39}

Quadrini, Vincenzo (1999),

"The Importance of Entrepreneurship for Wealth Concentration and Mobility", Review of Income and Wealth, 45, 1, March.

Rebelein, Robert and Jerry Tempalski (2000),

"Who Pays the Individual AMT?", Office of Tax Analysis Working Paper 87, US Treasury Department.

Ring, Raymond J., Jr. (1999),

“Consumers' Share and Producers' Share of the General Sales Tax”, National Tax Journal, 52, 1.

Rosenbaum, Dan T. (2000),

"Taxes, the Earned Income Tax Credit and Marital Status", Joint Centre for Poverty Research Working Paper 177, Northwestern University and University of Chicago, May.

Shaviro, Daniel (1993),

Federalism in Taxation: the Case for Greater Uniformity, AEI Studies in Regulation and Federalism, American Enterprise Institute Press, Washington, D.C.

Slemrod, Joel (2001),

"Thoughts on the Growing Concentration of Income Subject to Tax", Private Communication, Version of 25 April.

Slemrod, Joel and Jan Bakija (2000),

"Does Growing Inequality Reduce Tax Progressivity? Should It?", National Bureau of Economic Research Working Paper 7576, March.

Small, Kenneth A. and Jose A. Gómez-Ibáñez (1999),

"Urban Transportation", in Paul Cheshire and Edwin S. Mills, Handbook of Regional and Urban Economics, Volume 3, Applied Urban Economics, North-Holland, Amsterdam.

Triest, Robert K. (1996),

"Fundamental Tax Reform and Labour Supply", in Henry J. Aaron and William G. Gale (eds.), Economic Effects of Fundamental Tax Reform, Brookings Institution Press, Washington, D.C.

US Treasury (2000),

"The Deferral of Income Earned Through US Controlled Foreign Corporations A Policy Study", Office of Tax Policy. 


\section{ANNEX}

\section{MAIN FEATURES OF THE TAX SYSTEM IN 2000/01 ${ }^{1}$}

\section{The personal income tax}

\subsection{Federal government income taxes}

US citizens and residents are subject to taxation on their worldwide income even if they are resident outside the United States.

\section{Tax rates and brackets}

Families are taxed in one of three ways:

- As married filing jointly (or qualifying widow or widower) on the combined income of both spouses;

- As married filing separately and reporting actual income of each spouse;

- As heads of household (only unmarried or separated with dependants).

All others, including dependent children with sufficient income, file as single individuals.

\begin{tabular}{|c|c|c|c|c|c|}
\hline \multicolumn{6}{|c|}{ Tax rates and brackets } \\
\hline Filing status & Tax rates & $\begin{array}{c}\text { Brackets } \\
\text { US\$ }\end{array}$ & Filing status & Tax rates & $\begin{array}{c}\text { Brackets } \\
\text { US\$ }\end{array}$ \\
\hline Single individuals & $\begin{array}{c}15 \\
28 \\
31 \\
36 \\
39.6\end{array}$ & $\begin{array}{c}0-26250 \\
26250-63550 \\
63550-132600 \\
132600-288350 \\
\text { Above } 288350\end{array}$ & Married filing jointly & $\begin{array}{c}15 \\
28 \\
31 \\
36 \\
39.6\end{array}$ & $\begin{array}{c}0-43850 \\
43850-105950 \\
105950-161450 \\
161450-288350 \\
\text { Above } 288350\end{array}$ \\
\hline Married filing separately & $\begin{array}{c}15 \\
28 \\
31 \\
36 \\
39.6\end{array}$ & $\begin{array}{c}0-21925 \\
21925-52975 \\
52975-80725 \\
80725-144175 \\
\text { Above } 144175\end{array}$ & Head of household & $\begin{array}{c}15 \\
28 \\
31 \\
36 \\
39.6\end{array}$ & $\begin{array}{c}0-35150 \\
35150-90800 \\
90800-147050 \\
147050-288350 \\
\text { Above } 288350\end{array}$ \\
\hline
\end{tabular}

The tax brackets are adjusted annually for inflation.

Tax base: All households are liable for income tax on gross income. Gross income is income from all sources: wages and salaries, unemployment compensation, tips and gratuities, interest, dividends,

1. Sources: OECD (2000), Taxing wages 1999-2000; Duncan, H.T. and C.E. McLure Jr., (1997). 
annuities, pensions, rents, royalties, capital gains, alimony, social security benefits if the recipient's income exceeds a base amount, and other types of income. Among the items excluded from gross income, and thus not subject to tax, are public assistance benefits and interest on exempt securities (mostly state and local bonds). Taxable income is adjusted gross income (AGI) minus personal exemptions of $\$ 2800$ per taxpayer or dependent and minus either the itemised deduction or the standard relief as elected by the taxpayer. AGI is gross income minus the adjustments for expenses ordinary and necessary to carrying on one's trade or business, capital losses (with certain limitations), alimony paid to a former spouse, and other fairly specific deductions. The above rates are used to compute a household's or individual's regular federal tax liability. The United States also imposes the alternative minimum tax (AMT) at a rate of 26 per cent on the alternative minimum taxable income up to $\$ 175000$, and a rate of 28 per cent on the alternative minimum taxable income exceeding $\$ 175000$. A number of deductions allowable against standard taxation are added back to taxable base of the AMT. It is an alternative tax because households must compute both the regular tax and the AMT liabilities. The greater of the two amounts constitute the final liability.

\section{Tax allowances and tax credits}

\section{Standard relief}

Basic relief: Taxpayers who do not itemise their deductions are entitled to a lump-sum standard deduction, which replaces the zero bracket amount that was built into the tax rate schedules under prior law. In 2000 a married couple filing a joint tax return is entitled to a standard deduction of $\$ 7350$. The standard deduction is $\$ 6450$ for heads of households and $\$ 4400$ for single individuals. This relief is indexed for inflation. A special rule applies to children who have sufficient income to pay tax and are also claimed as dependants by their parents. For such children, the standard deduction is the lesser of $\$ 700$ or the amount of their earned income plus $\$ 250$ or the standard deduction to which they would otherwise be entitled. Also, to prevent transfer of income-producing property from parents to children in order to avoid the higher tax rate of the parents, the net unearned income of a child under age 14 that exceeds the sum of the $\$ 700$ deduction plus the greater of $\$ 700$ or the itemised deductions directly related to the production of that income is taxed at the parents' top marginal tax rate. More liberal standard deductions are available for taxpayers that are aged 65 or older and taxpayers that are blind. These benefits replace additional personal exemptions available for the elderly and the blind under prior law.

Relief for children: For each child and other persons claimed as dependent on a taxpayer's return, the taxpayer is entitled to a dependency exemption of $\$ 2800$. Low-income workers with qualifying children are allowed a refundable (non-wasteable) earned income credit (EITC). For taxpayers with one child, the credit is 34 per cent of up to $\$ 6920$ of earned income. The credit phases down when income exceeds $\$ 12690$ and phases out when it reaches \$27 413. Both the earned income and the phase-out thresholds are indexed for inflation. For taxpayers with two or more children, the credit is 40 per cent of up to $\$ 9726$ of earned income in 1999. The credit phases down when income exceeds $\$ 12690$ and phases out when it reaches $\$ 31$ 152. Beginning in 1998, taxpayers are permitted a tax credit for each qualifying child under the age of 17 equal to $\$ 500$ per child. The maximum credit is reduced for taxpayers with income in excess of certain thresholds. The credit is reduced by $\$ 50$ for each $\$ 1000$ of income in excess of $\$ 110000$ for married taxpayers ( $\$ 75000$ for single and head of household taxpayers). These threshold amounts are not indexed for inflation. A taxpayer with three or more qualifying children may be allowed a supplemental refundable (non-wasteable) child credit, subject to certain restrictions. The refundable amount is equal to the amount by which the child credit exceeds the taxpayer's tax liability, but cannot exceed the taxpayer's social security taxes less the earned income credit received.

Relief for low income workers without children: In 1994 and thereafter, low income workers without children are eligible for the earned income credit (EITC). In 2000 low-income workers without children 
are permitted a non-wasteable earned income credit of 7.65 per cent of up to $\$ 4610$ of earned income. The credit phases down when income exceeds $\$ 5770$ and phases out when income reaches $\$ 10380$. This credit is available for taxpayers at least 25 years old and under 65 years old.

Relief for social security and other taxes: There is no special relief for social security taxes although the non-wasteable earned income credits described above are sometimes considered an offset to social security contributions made by eligible employees. Furthermore, only a portion of social security benefits are subject to tax. Benefits included in income for tax purposes are limited to the lesser of one-half of the annual benefits received for the year or the excess of the taxpayers' income (including one-half of the benefits) over $\$ 32000$ for married couples and $\$ 25000$ for others. However, up to 85 per cent of benefits could be included in income for tax purposes if the taxpayers' income (including one-half the benefits) exceeds $\$ 44000$ for married couples and $\$ 34000$ for others. Also, for taxpayers who do not elect the optional standard deduction, State and local taxes other than taxes on retail sales are generally deductible in computing federal taxable income.

\section{Main non-standard types of relief applicable to an APW}

The basic non-standard relief is the deduction of certain expenses to the extent that, when itemised, they exceed in aggregate the standard deduction. The principal itemised deductions claimed by individuals are:

- Medical and dental expenses that exceed 7.5 per cent of income;

- State and local income, real property, and personal property taxes (but not sales taxes);

- Home mortgage interest;

- Investment interest expense up to investment income with an indefinite carry forward of disallowed investment interest expense;

- Contributions to qualified charitable organisations (including religious and educational institutions);

- Casualty and theft losses to the extent that each loss exceeds \$100 and that all such losses combined exceed 10 per cent of income; and

- Miscellaneous expenses such as non-reimbursed employee business expenses (union dues, work shoes, etc.), investment expenses, tax return preparation fees and educational expenses required by employment, to the extent that, in aggregate, they exceed 2 per cent of income.

Otherwise allowable itemised deductions are reduced by 3 per cent of the amount by which income exceeds \$128 950 (\$64 475 for married individuals filing separately). However, the reduction is limited to 80 per cent of the total of otherwise allowable itemised deductions other than the allowable itemised deductions for medical expenses, investment interest, theft and casualty losses, and gambling losses

\section{Income taxed at preferential terms}

\section{Capital gains}

Net capital gain income is taxed at ordinary income rates, except that the maximum rate for longterm gains is limited to 20 per cent ( 10 per cent for individuals in the 15 per cent bracket). Net capital gain is equal to the difference between net long-term capital gains and net short-term capital losses. Long-term 
refers to assets held longer than 12 months. A special rate of 18 per cent ( 8 per cent for individuals in the 15 per cent bracket) applies to assets whose holding period begins after 31 December 2000 and that are held longer than five years and sold after 31 December 2000.

\section{Private saving plans}

Contributions to pension and life insurance plans. No relief is provided for employee contributions to employer sponsored pension plans or for life insurance premiums. However, employees are allowed to deduct contributions to an individual retirement account (IRA) of up to $\$ 2000$ per year (\$4 000 in the case of a married employee with a non-working spouse subject to certain restrictions). If a taxpayer is a participant in an employer-maintained retirement plan, then the $\$ 2000$ limit is reduced to zero over the income range, $\$ 32000$ to $\$ 42000$ for a single tax payer (\$52 000 to $\$ 62000$ if husband and spouse file a joint return). Earnings on these accounts are not subject to current taxation but a 10 per cent penalty generally applies if a withdrawal is made before the taxpayer attains age 59 years and 6 months.

Beginning in 1998, individuals can make non-deductible contributions of up to $\$ 2000$ to a new IRA ("Roth IRA"). The maximum annual contribution to this IRA is reduced by the amount contributed to the IRA described above. The maximum annual contribution to the Roth IRA is phased out over the income range $\$ 95000$ to $\$ 110000$ for a single taxpayer ( $\$ 150000$ and $\$ 160000$ if husband and spouse file a joint return). Earnings on these accounts are not taxed but must meet certain holding period and other requirements.

Employees, as well as employers, may make contributions to a qualified retirement plan. Employees may, subject to certain restrictions, make both pre-tax and after-tax contributions to a qualified plan. Pre-tax employee contributions (e.g. contributions to a qualified cash or deferred arrangement section "401(k) plan") are generally treated the same as employer contributions for tax purposes. The tax treatment of contributions under qualified plans is essentially the same as that of deductible IRAs. However, the limits on contributions to qualified plans are much higher than the IRA contribution limits, so that qualified plans provide for a greater accumulation of funds on a tax-favoured basis.

\section{Withholding taxes}

Wages and salaries are subject to withholding tax, which is collected by the employer. Withheld taxes are fully credited against tax liability calculated using annual income. Social Security tax is also collected at source by withholding.

Non-residents are subject to withholding tax at a rate of 30 per cent on rents, royalties, salaries, wages premiums, annuities, compensations, remuneration, interests and dividends. Payments to residents of countries with which the United States has an income tax treaty may be subject to a reduced or zero rate of withholding.

\subsection{State individual income taxes}

Tax rates: Six states levy a flat-rate individual income tax, most employ graduated rates. For the most part, top marginal state tax rates are clustered in the range of 5-9 per cent; in fewer than ten states does the top marginal rate exceed 10 per cent (see Table A1). Local jurisdictions (primarily cities) in 13 states also impose individual income taxes. Three states collect a flat percentage of federal income tax liability and one state collects a flat percentage of federal taxable income. 
ECO/WKP(2001)39

Table A1. State individual and corporate income taxes: top marginal rates ${ }^{1}$

\begin{tabular}{ccc}
\hline Top marginal rates & $\begin{array}{c}\text { Number of states } \\
\text { Individual }\end{array}$ & $\begin{array}{c}\text { Number of states } \\
\text { Corporate }\end{array}$ \\
\hline 0 per cent $-<5$ per cent & 7 & 4 \\
5 per cent $-<6$ per cent & 6 & 5 \\
6 per cent $-<7$ per cent & 12 & 10 \\
7 per cent $-<8$ per cent & 5 & 6 \\
8 per cent $-<9$ per cent & 5 & 9 \\
9 per cent $-<10$ per cent & 3 & 9 \\
10 per cent or greater & $5^{2}$ & 2 \\
\hline
\end{tabular}

1. Five states do not levy either individual or corporate income tax: Nevada, South Dakota, Texas, Washington and Wyoming. Additionally, Arkansas, Florida, New Hampshire and Tennessee levy only limited or no individual income tax.

2. Three states in this category base their individual income tax rates on a percentage of the taxpayer's federal income tax liability.

Source: http://www.taxfoundation.org/statefinance.html.

Tax base: Most states base the state individual income tax on federal law and they conform to the concept of adjusted gross income under federal law. In three states, state tax liability is calculated simply as a percentage of federal AGI with some modification and in three others, state tax liability is calculated simply as a percentage of federal liability.

\section{Social security contributions}

\section{Social Security Tax}

Under the Federal Insurance Contributions Act (FICA), social security tax is imposed on wages or salaries received by individual employees to fund retirement benefits paid by the federal government. The social security tax of 15.3 per cent, which includes a 2.9 per cent Medicare tax, is imposed on the first $\$ 76200$ of annual employment income. However, no limit applies to the amount of wages subject to the Medicare portion of the social security tax. Half of the tax is withheld from the employee's wages, and half is paid by the employer. FICA tax is imposed on compensation for services performed in the United States, regardless of the citizenship or residence of the employee or employer.

\section{Self-employment Tax}

Self-employment tax is imposed under the Self-employment Contributions Act (SECA) on self-employment income, net of business expenses, that is derived by US citizens and resident aliens. For 2000, SECA tax is imposed at a rate of 15.3 per cent, which includes a 2.9 per cent Medicare tax, on self-employment income, up to $\$ 76200$. However, no limit applies to the amount of income subject to the Medicare portion of SECA tax. Self-employed individuals must pay the entire tax but may deduct 50 per cent as a trade or business expense on their federal income tax return. No tax is payable if net earnings for the year are less than $\$ 400$. If a taxpayer has both wages subject to FICA tax and income subject to SECA tax, the wage base subject to FICA tax is used to reduce the income base subject to SECA tax. SECA tax is computed on the individual's US income tax return. Non-resident aliens are not subject to SECA tax. 


\section{Federal Unemployment Tax}

Federal unemployment tax (FUTA) is imposed on employers' wage payments to employees. FUTA is imposed on income from services performed within the United States, regardless of the citizenship or residency of the employer or employee. It is also imposed on wages for services performed outside the United States for a US employer by US citizens. The 2000 tax rate is 6.2 per cent on the first $\$ 7000$ of wages of each employee. All states also have unemployment taxes that are creditable against FUTA tax when paid. For employers who pay their state unemployment taxes on a timely basis, the after-credit FUTA rate is 0.8 per cent. Self-employed individuals are not subject to FUTA tax and cities in three other states impose payroll taxes. Such payroll taxes are commonly intended to collect tax from individuals who work in the taxing city but reside in another. Some states allow resident individual a credit for income and payroll taxes paid to localities in other states.

\section{The corporate income tax}

\subsection{The federal corporate income tax}

US corporations are subject to federal taxes on their worldwide income, including income of foreign branches (whether or not the profits are repatriated). In general, a US corporation is not taxed by the United States on the earnings of a foreign subsidiary until the subsidiary distributes dividends or is sold or liquidated. Numerous exceptions to this deferral concept may apply, resulting in current US taxation of some or all of the foreign subsidiary's earnings. Branches of foreign corporations generally are taxable on income that is effectively connected with a US trade or business. However, if the foreign corporation is resident in a country having an income tax treaty with the United States, business profits are taxable by the United States only to the extent the income is attributable to a permanent establishment in the United States.

Rates: A corporation's taxable income exceeding \$75 000 but not exceeding \$10 million is taxed at 34 per cent. Corporations with taxable income between $\$ 335000$ and $\$ 10$ million are effectively taxed at 34 per cent on all taxable income (including the first $\$ 75000$ ). Corporations with taxable income of less than $\$ 335000$ receive partial benefit from the graduated rates of 15 per cent and 25 per cent that apply to the first $\$ 50000$ and $\$ 75000$ of taxable income respectively. A corporation's taxable income exceeding \$15 million but not exceeding \$18 333333 is subject to an additional tax of 3 per cent. Corporations with taxable income in excess of \$18 333333 are effectively subject to tax at a rate of 35 per cent on all taxable income. These rates apply both to US corporations and to the income of foreign corporations that is effectively connected with a US trade or business.

\section{Alternative Minimum Tax}

The alternative minimum tax (AMT) is designed to prevent corporations with substantial economic income from using preferential deductions, exclusions and credits to substantially reduce or eliminate their tax liability. To achieve this goal, the AMT is structured as a separate tax system with its own allowable deductions and credit limitations. The tax is imposed at a flat rate of 20 per cent on alternative minimum taxable income (AMTI). It is an "alternative" tax because corporations are required to pay the higher of the regular tax or AMT. To the extent the AMT exceeds regular tax, a minimum tax credit is generated and carried forward to offset the taxpayer's regular tax to the extent it exceeds the AMT in future years. In general, AMTI is computed by making the adjustments to regular taxable income and then adding back certain non-deductible tax preference items. For example, net operating losses and foreign tax credits may reduce AMT by up to 90 per cent, compared to a potential reduction of 100 per 
cent for regular tax purposes. An AMT exemption applies to small business corporations that meet certain income requirements.

\section{Capital gains and losses}

Capital gains are generally taxed at the same rate as ordinary income. In general, capital losses may offset only capital gains, not ordinary income. A corporation's excess capital loss may be carried back three years and forward five years to offset capital gains in such other years.

\section{Foreign tax relief}

A tax credit is allowed for foreign income taxes paid, or deemed paid, by US corporations, but it is limited to the US tax on the foreign-source portion of a company's worldwide taxable income. Separate limitations must be calculated based on various categories of income, including the following: passive income; high withholding tax interest income; and dividend income from each foreign corporation in which the company holds a 10 per cent or greater interest and all US shareholders hold a total interest of less than 50 per cent. In addition, foreign tax credits, together with net operating loss deductions, may only reduce up to 90 per cent of the AMT.

\section{The tax base}

\section{General}

Income for tax purposes is generally computed according to generally accepted accounting principles, as adjusted for certain statutory tax provisions. Consequently, taxable income frequently does not equal income for financial reporting purposes. In general, a deduction is permitted for ordinary and necessary trade or business expenses. However, expenditures that creates an asset having a useful life longer than one year may need to be capitalised and recovered rateably.

\section{Depreciation}

A depreciation deduction is available for most property (except land) used in a trade or business or held for the production of income, such as rental property. Tangible depreciable property that is used in the United States (whether new or used) and placed in service after 1980 and before 1987 is generally depreciated on an accelerated basis (ACRS). Tangible depreciable property that is used in the United States and placed in service after 1986 is generally depreciated under a modified ACRS basis. In general, under the modified ACRS system, assets are grouped into six classes of personal property and into two classes of real property. Each class is assigned a recovery period and a depreciation method. The following are the depreciation methods and recovery periods for certain assets. 


\begin{tabular}{lll}
\hline Asset & Depreciation method & Recovery period (years) $^{1}$ \\
\hline Commercial and industrial buildings & Straight-line & $39^{2}$ \\
Office furniture & Double-declining balance & 7 \\
Motor vehicles and computer equipment & Double-declining balance & 5 \\
& & \\
\hline
\end{tabular}

1. These are the recovery periods, in general. Specific variations within a category can occur.

2. 31.5 years if placed in service before 13 May 1993.

Alternatively, a taxpayer may elect to use the straight-line method of depreciation over specified longer recovery periods or the methods prescribed for AMT purposes, which would avoid a depreciation adjustment for AMT.

The cost of intangible assets developed by a taxpayer may be amortised over the determinable useful life of an asset. If the asset has no determinable life its cost can be expensed. Certain intangible assets, including goodwill, going concern value, patents and copyrights, may generally be amortised over 15 years if they are acquired as part of a business after 10 August 1993. A taxpayer may elect to apply this provision to all property acquired after 25 July 1991.

Tax depreciation is generally subject to recapture on the sale of an asset to the extent the sales proceeds exceed the tax value after depreciation. The amounts recaptured are subject to tax as ordinary income.

\section{Net Operating Losses}

If allowable deductions of a US corporation or branch of a foreign corporation exceed its gross income, the excess is called a net operating loss (NOL). In general, NOLs may be carried back two years and forward 20 years to offset taxable income in those years. A specified liability loss (product liability loss) may be carried back 10 years. Commercial banks may carry back bad debt losses ten years and carry forward such losses 5 years. A real estate investment trust (REIT) may not carry back an NOL to a tax year in which the entity operated as a REIT. Farming business losses may be carried back five years. Limitations apply in utilising NOLs of acquired operations.

\section{Inventories}

Inventory is generally valued for tax purposes at either cost or the lower of cost or market value. In determining the cost of goods sold, the two most common inventory flow assumptions used are last-in, first-out (LIFO) and first-in, first-out (FIFO). The method chosen must be applied consistently. Uniform capitalisation rules require the inclusion in inventory costs of many expenses previously deductible as period costs.

\section{Dividends}

In general, dividends received from other US corporations qualify for a 70 per cent dividends-received deduction, subject to certain limitations. The dividends-received deduction is generally increased to 80 per cent of the dividend if the recipient corporation owns at least 20 per cent of the distributing corporation. Dividend payments between members of an affiliated group of US corporations 
qualify for a 100 per cent dividends-received deduction. In general, an affiliated group consists of a US parent corporation and all other US corporations in which the parent owns, directly or indirectly through one or more chains, at least 80 per cent of the total voting power and value of all classes of shares (excluding non-voting preferred shares).

\section{Consolidated returns}

An affiliated group of US corporations (as described in Dividends above) may elect to determine its taxable income and tax liability on a consolidated basis. The net operating losses of some members of the group can be used to offset the taxable income of other members of the group, and transactions between group members, such as inter-company sales and dividends, are generally deferred or eliminated until there is a transaction outside the group. Under certain circumstances, losses incurred on the sale of consolidated subsidiaries are disallowed.

\section{Foreign subsidiaries}

Under certain circumstances, undistributed income of a foreign subsidiary controlled by US shareholders is taxed to the US shareholders on a current basis, as if the foreign subsidiary distributed a dividend on the last day of its taxable year. This may result if the foreign subsidiary invests its earnings in "US property" (including loans to US shareholders) or earns certain types of income (referred to as "Sub-part F" income), including certain passive income and "tainted" business income.

Two other regimes restrict the deferral of tax on offshore income. The foreign personal holding company (FPHC) rules apply to foreign corporations with predominantly passive income that are closely held by US individual shareholders. The passive foreign investment company (PFIC) rules apply to foreign corporations with a high percentage of passive income or passive assets. The PFIC rules do not include a minimum threshold of ownership by US shareholders.

\section{Other tax rules}

\section{Debt-to-equity rules}

The United States has thin-capitalisation principles under which the Internal Revenue Service (IRS) may attempt to limit the deduction for interest expense if a US corporation's debt-to-equity ratio is too high. If a US corporation is thinly capitalised, funds loaned to it by a related party may be re-characterised by the IRS as equity. As a result, the corporation's deduction for interest expense may be disallowed, and principal and interest payments may be considered distributions to the related party and be subject to withholding tax. The United States has no fixed rules for determining if a thin-capitalisation situation exists. A debt-to-equity ratio of 3:1 or less is usually acceptable to the tax authorities, provided the taxpayer can adequately service its debt without the help of related parties. However, a deduction is disallowed for certain "disqualified" interest paid on loans made or guaranteed by related foreign parties that are not subject to US tax on the interest received. This disallowed interest may be carried forward to future years and allowed as a deduction. No interest deduction is disallowed under this provision if the payer corporation's debt-to-equity ratio does not exceed 1.5:1. If the debt-to-equity ratio exceeds this amount, the deduction of "excess interest expense" is deferred. "Excess interest expense" is defined as the excess of interest expense over interest income, minus 50 per cent of the adjusted taxable income of the corporation plus any "excess limitation carry-forward". 


\section{Transfer pricing}

In general, the IRS may re-compute the tax liability of related parties if, in its discretion, it is necessary to prevent the evasion of taxes or to clearly reflect income. Specific regulations require that related taxpayers (including United States and foreign affiliates) deal among themselves on an arm's length basis. Under the best-method rule included in the transfer-pricing regulations, the best transfer-pricing method is determined based on the facts and circumstances. Transfer-pricing methods that may be acceptable, depending on the circumstances, include uncontrolled price, resale price and profit-split. It is possible to reach transfer-pricing agreements in advance with the IRS. If the IRS adjusts a taxpayer's tax liability, tax treaties between the United States and other countries usually provide procedures for allocation of adjustments between related parties in the two countries to avoid double tax.

\section{Related-party loans}

Under US Treasury regulations, interest expense accrued on a loan from a related foreign lender must be actually paid before the US borrower can deduct the interest expense.

\section{Treaty withholding tax rates}

The United States withholding tax rates for dividend, interest and royalty payments from the United States to residents of various treaty countries ranges from 0 to 30 per cent depending on the treaty.

\subsection{The state corporate income tax}

Tax rates: All but 13 of the 46 states levying a corporate income tax employ a single rate. In those with a graduated rate, the top marginal rate is generally reached at a low level (less than \$250 000 net income in all but one state). State corporate income tax rates are generally clustered in the 6 to 9 per cent range (see Table A1). Local corporate income taxes are permitted in six states - Kentucky, Michigan, Missouri, New York, Ohio and Oregon. Rates range from 0.5 per cent in Missouri to nearly 8 per cent in New York City.

Tax base: The calculation of the state corporate income tax base differs from the federal tax base. Starting from the federal tax base, each state requires certain additions and allows certain subtractions in calculating income for state tax purposes. Among the most important additions are: interest exempt under federal law (interest on the debt of state and local governments), income taxes of other states (allowed as a deduction in calculating federal tax), depreciation allowances (to the extent that federal law is more generous than state law), and net operating losses from prior years allowed as a deduction in calculating federal tax liability. "Subtractions" include depreciation allowances in excess of those under federal law and interest on obligations of the federal government. States allow a variety of credits against the tax liability, notably for investment in pollution control and water conservation facilities. In addition, nearly all states allow some credits for increased investment and job creation in specified areas of the state called "enterprise zones". This is also generally applicable to the calculation of business income of individuals not operating in corporate form.

\section{The federal estate and gift tax}

The federal estate tax is computed by applying a rate schedule that ranges from 18 to 55 per cent, with a surtax of 5 per cent that applies to taxable estates between $\$ 10$ and $\$ 17$ million. There is a lifetime 
tax credit that is equal to the tax payable on an estate of $\$ 675000$. The effect of this credit is that the lowest marginal tax rate on transfers is 37 per cent rising to 60 per cent as the tax credit is phased out. Under current law, this tax credit is set to the equivalent of the tax paid on an estate of \$2 million in 2006 and the first marginal tax rate will rise to 46 per cent. Transfers to spouses are taxed at a zero rate. The tax is also reduced by a credit for state estate taxes.

The gift tax is integrated with the estate tax and it is levied on gifts of $\$ 10000$ per year per donee. For a married couple, a gift can be split between the spouses given consent by both spouses, thus $\$ 20000$ per year can be given tax-free to an unlimited number of people. An unlimited exemption is granted for tuition and medical expenses and charity donations. No credit is granted for state taxes. Unlike the estate tax, the gift tax applies on a tax-exclusive basis, which may provide a sizeable tax advantage to giving gifts rather than leaving bequests. For example, for an individual who wishes to transfer his wealth to his children, the gift tax of 50 per cent is applied to the net amount they receive. In effect, the tax rate is only 33.3 per cent of the gross amount transferred and is therefore lower than the estate tax rate.

For capital gains purposes, the basis of appreciated assets is "stepped-up" to the market value at death: when the heirs sell the inherited assets, gains accrued by the decedents are never subject to the capital gains tax. The donor's cost of basis is carried over as the asset's basis, when the asset is transferred inter vivos. In this case if the donee sells the asset, capital gains that accrued before the gift was made would be subject to capital gains taxation.

\section{Consumption taxes}

\subsection{Federal consumption taxes}

\section{A. Highway Trust Fund Excise Taxes}

Six separate excise taxes are imposed to finance the Federal Highway Trust Fund programme. Three of these taxes are imposed on highway motor fuels. The remaining three are a retail sales tax on heavy highway vehicles, a manufacturer's excise tax on heavy vehicle tires, and an annual use tax on heavy vehicles. The six taxes are summarised below.

\section{Highway motor fuels taxes}

The Highway Trust Fund ${ }^{2}$ motor fuels tax rates are as follows:

\author{
Gasoline \\ Diesel fuel and kerosene \\ Special motor fuels
}

18.3 cents per gallon 24.3 cents per gallon 18.3 cents per gallon

2. These fuels are subject to an additional 0.1 cent per gallon excise tax to fund the Leaking Underground Storage Tank ("LUST") Trust Fund. That tax is imposed as an "add-on" to other existing taxes; thus most of the simplification recommendations discussed in this section for motor fuels taxes also would apply to the LUST tax. 


\section{ECO/WKP(2001)39}

follows:

The statutory rate for certain special motor fuels is determined on an energy equivalent basis, as

Liquefied petroleum gas (propane)

Liquefied natural gas

Methanol derived from petroleum or natural gas

Compressed natural gas
13.6 cents per gallon

11.9 cents per gallon

9.15 cents per gallon

48.54 cents per $\mathrm{MCF}$

\section{Special motor fuels}

The special motor fuels tax is imposed on retail sale of the fuel, or on use if the fuel is consumed before a retail sale occurs.

\section{Exemptions and reduced rates}

Numerous exemptions (and partial exemptions) for specified uses of taxable fuels (or for specified fuels) are provided under present law. Typically, these exemptions are for governments or for uses not involving use of (and thereby damage to) the highway system. These exempt uses include:

- Use in State or local government and nonprofit educational organisation vehicles;

- Use in certain buses engaged in transporting students and employees of schools;

- Use in private local mass transit buses having a seating capacity of at least 20 adults (not including the driver) when the buses operate under contract with (or are subsidised by) a State or local government unit;

- Use of gasoline or special motor fuels in an off-highway business use or of diesel fuel or kerosene in an off-highway use (whether or not a business use).

Diesel fuel and kerosene used in certain inter-city buses is taxed at a special, reduced rate of 7.3 cents per gallon.

Ethanol and methanol derived from renewable sources (e.g. biomass) are eligible for an income tax credit (the "alcohol fuels credit") equal under present law to 53 cents per gallon (ethanol) $)^{3}$ and 60 cents per gallon (methanol). ${ }^{4}$ These tax credits are provided to blenders of the alcohols with other taxable fuels, or to retail sellers of unblended alcohol fuels. Part or all of the benefits of the income tax credit may be claimed through reduced excise taxes paid, either in reduced-tax sales or by expedited blender refunds on fully taxed sales of gasoline.

3. The 53 cents per gallon credit is scheduled to decline to 51 cents per gallon ver the period 2001 through 2007.

4. Ethanol produced by certain "small producers" is eligible for an additional 10 cents per gallon producer tax credit. Eligible small producers are defined as persons whose production capacity does not exceed 30 million gallons and whose annual production does not exceed 15 million gallons. 


\section{Non-fuels excise taxes}

Retail sales tax on tractors, heavy trucks and heavy trailers

A 12 per cent retail sales tax is imposed on the first retail sale of tractors, heavy trucks (over 33000 pounds) and trailers (over 26000 pounds). The taxable weight is the "gross vehicle weight", which is fully loaded, certified weight. In general, this tax is imposed on the price of a fully equipped highway vehicle. However, the price of certain equipment unrelated to the highway transportation function of the vehicle is excluded from the tax base. Additionally, a credit against the tax is allowed for the amount of tire excise tax imposed on manufacturers of new tires installed on the vehicle.

The term first retail sale includes the first sale of a "remanufactured" vehicle.

\section{Manufacturers tax on heavy vehicle tires}

Tires designed for use on heavy highway vehicles are subject to a graduated tax, based on the weight of the tire.
40 pounds or less
No tax
40 - 70 pounds
15 cents per pound 40 pounds
70 - 90 pounds
$\$ 4.50$ plus 30 cents per pound over 70 pounds
Over 90 pounds
$\$ 10.50$ plus 50 cents per pound over 90 pounds

Retread tires are not subject to tax except when the retreading covers the entire outer surface of the tire (i.e. is "bead to bead").

\section{Annual use tax for heavy vehicles}

An annual use tax is imposed on heavy highway vehicles, at the rates below.

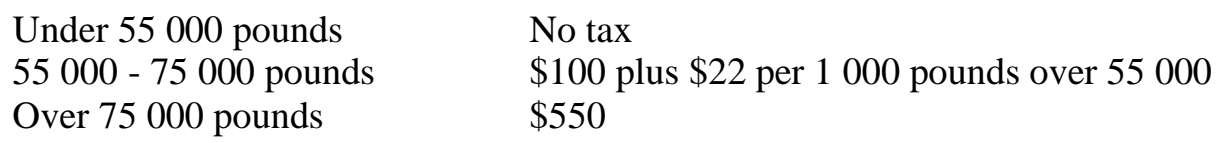

The annual use tax is imposed for a taxable period of 1 July through 30 June. Generally, the tax is paid by the person in whose name the vehicle is registered. In certain cases, taxpayers are allowed to pay the tax in quarterly instalments. Exemptions and reduced rates are provided for certain "transit-type buses", trucks used for fewer than 5000 miles on public highways (7 500 miles for agricultural vehicles), and logging trucks.

\section{B. Airport and Airway Trust Fund Excise Taxes}

Four separate excise taxes are imposed to finance the Federal Airport and Airway Trust Fund programme. The taxes are:

- Ticket taxed imposed on commercial passenger transportation;

- A waybill tax imposed on freight transportation; and 
- Two separate fuels taxes imposed on gasoline and jet fuel used in commercial aviation and non-commercial aviation. ${ }^{5}$

\section{Non-fuels taxes on commercial transportation by air}

\section{Passenger transportation}

Most domestic air passenger transportation is subject to a two-part excise tax. ${ }^{6}$ First, an ad valorem tax is imposed at the rate of 7.5 per cent of the amount paid for the transportation. Second, a flight segment tax of $\$ 2.75$ per segment is imposed. The flight segment tax is scheduled to increase to \$3 (1 January 2002 to 31 December 2002). Beginning on 1 January 2003, and each 1 January thereafter, the flight segment tax will be indexed annually for inflation occurring after calendar year 2001. A flight segment is defined as transportation involving a single take-off and a single landing. In addition, airports can level a Passenger Facility Charge of up to $\$ 4.50$.

The flight segment component of the tax does not apply to segments to or from qualified "rural airports". A rural airport is defined as an airport that $(i)$ in the second preceding calendar year had fewer than 100000 commercial passenger departures, and (ii) either (a) is not located within 75 miles of another airport that had more than 100000 such departures in that year, or $(b)$ is eligible for payments under the Federal "essential air service" programme.

International air passenger transportation is subject to a tax of $\$ 12.80$ per arrival or departure in lieu of the taxes imposed on domestic air passenger transportation. The international air transportation tax rate is indexed for inflation annually, effective on each 1 January. The definition of international transportation includes certain purely domestic transportation that is associated with an international journey. Under these rules, a passenger travelling on separate domestic segments integral to international travel is exempt from the domestic passenger taxes on those segments if the stopover time at any point within the United States does not exceed 12 hours.

Both of the preceding taxes apply only to transportation for which an amount is paid. Thus, free travel such that awarded in "frequent flyer" programs and non-revenue travel by airline industry employees is not subject to tax. However, amounts paid to air carriers (in cash or in kind) for the right to award free or reduced-fare transportation are treated as amounts paid for taxable air transportation, subject to 7.5 per cent ad valorem tax rate (but not the flight segment rate or the international air passenger tax). This tax applies to payments, whether made within the United States or elsewhere, if the rights to transportation for which the payments are made can be used in whole or in part for transportation that if purchased directly, would be subject to either the domestic or international air passenger taxes.

5. The tax rates vary both by fuel and by the type of aviation in which the fuel is used. Commercial aviation is defined as transportation "for hire" of passengers or freight. All other air transportation is defined as non-commercial aviation. Because these definitions are based on whether an amount is paid for the transportation, it is possible for the same aircraft to be used at times in commercial aviation and at times in non-commercial aviation. This determination is made on a flight-by-flight basis. For example, a corporate-owned aircraft transporting employees of the corporation is engaged in non-commercial aviation (and subject to a mix of ticket and fuels taxes).

6. Special rules apply to transportation between the 48 contiguous States and Alaska or Hawaii (or between Alaska and Hawaii) and to certain transportation between the United States and points within the "225-mile zone" of Canada or Mexico or within that zone (when the transportation is purchased within the United States). 
Passengers and transportation providers both are liable for payment of the air passenger excise taxes. Transportation providers are subject to special penalties if they do not separately disclose the amount of the passenger taxes on tickets and in advertising.

Unlike the air passenger taxes, only shippers are liable for payment of the air freight tax. Transportation providers are subject to penalties if they fail to make reasonable efforts to collect the tax. There is no disclosure requirement for the air freight tax.

\section{Aviation fuels taxes}

Both aviation gasoline and jet fuel are subject to excise taxes. The tax rates are lower for commercial aviation (also subject to the non-fuels taxes described above) than for non-commercial aviation (subject only to fuels taxes). The fuels tax rates are shown below. ${ }^{7}$
Aviation gasoline
Commercial aviation
4.3 cents per gallon
Non-commercial aviation
19.3 cents per gallon
Jet fuel
Commercial aviation
4.3 cents per gallon
Non-commercial aviation
21.8 cents per gallon

The aviation gasoline tax is imposed on all gasoline removed from a registered pipeline or barge terminal in a transaction where the fuel "breaks bulk". (Typically, fuel breaks bulk when it is loaded into a rail car or a truck from the pipeline or barge terminal). The person liable for the tax is the owner of the fuel on the terminal records (the "position holder"). All parties owning non-tax-paid gasoline must be registered with the Internal Revenue Service. Exemptions generally are realised by refunds of tax previously paid.

The aviation jet fuel tax is imposed when the fuel is sold by a wholesale distributor. Most jet fuel is kerosene. The Highway Trust Fund provisions generally require payment of the highway excise tax on kerosene when the fuel is removed from a terminal unless the kerosene is dyed. A special exception to the dying requirement applies to aviation-grade kerosene. Aviation-grade kerosene may be removed from terminals without payment of the Highway Trust Fund excise taxes and without being dyed if it is removed for use as aeroplane fuel (i) by pipeline connected to an airport or (ii) by or on behalf of a registered aviation fuel dealer.

\section{Harbour maintenance trust fund excise tax and tax on passenger transportation by water}

The Code contains provisions imposing a 0.125 per cent excise tax on the value of most commercial cargo loaded or unloaded at US ports (other than ports included in the Inland Waterway Trust Fund system). The tax also applies to amounts paid for passenger transportation using these US ports. Exemptions are provided for (i) cargo donated for overseas use, (ii) possessions and (iii) cargo shipped between Alaska, Hawaii and/or US possessions. Receipts from this tax are deposited in the Harbor Maintenance Trust Fund.

7. Aviation fuels are subject to an additional 0.1 cent per gallon tax to fund the Leaking Underground Storage Tan ("LUST") Trust Fund. The tax is an add-on tax and could be affected by changes to the structure of the fuels taxes. 
A separate, $\$ 3$ per passenger General Fund excise tax is imposed on international passenger transportation by water. This tax applies to travel on a commercial passenger vessel by passengers embarking or disembarking in the United States if the travel extends over one or more nights. The tax also is imposed on commercial vessel transportation of passengers engaged in gambling aboard the vessel beyond the territorial waters of the United States (i.e. more than 3 miles from shore). The tax does not apply to a voyage on any vessel owned or operated by the United States or a State or any agency or political subdivision, nor does it apply to a voyage of fewer than 12 hours between two US ports. A passenger vessel is any vessel having berth or stateroom accommodations for more than 16 passengers.

\section{Aquatic resources trust fund excise taxes}

The Aquatic Resources Trust Fund is comprised of two accounts. First, the Boat Safety Account is funded by a portion of the receipts from the excise tax imposed on motorboat gasoline and special motor fuels. ${ }^{8}$ Transfers to the Boat Safety Account are limited to amounts not exceeding $\$ 70$ million per year. In addition, these transfers are subject to an overall annual limit equal to an amount that will not cause the Account to have an unobligated balance in excess of $\$ 70$ million.

Second, the Sport Fish Restoration Account receives the balance of the motorboat gasoline and special motor fuels receipts that are transferred to the Trust Fund. This Account also is funded with receipts from an ad valorem manufacturer's excise tax on sport fishing equipment. The general ad valorem rate is 10 per cent, the rate reduced to 3 per cent for electric outboard motors and certain fish finders. Examples of the items of sport fishing equipment subject to the 10 per cent rate include fishing rods and poles, fishing reels, fly fishing tackle, tackle boxes and containers designed to hold fish, fishing vests, landing nets, and portable bait containers.

A separate sub-account in the Sport Fish Restoration Account, the Wetlands Sub-Account, is funded with a portion of the general gasoline tax equal to the tax on gasoline used in nonbusiness off-highway use of small-engine outdoor power equipment.

Expenditures from the Boat Safety Account are subject to annual appropriations. Expenditures from the Sport Fish Restoration Account (including the Wetlands Sub-Account) are made pursuant to a permanent appropriation, enacted in 1951.

\section{E. Federal aid to wildlife fund and non-regular firearms excise taxes}

\section{Taxable articles}

The Federal Aid to Wildlife Fund (the "Wildlife Fund") programme is financed with receipts from ad valorem excise taxes imposed on the sale by the manufacturer of a taxable item or on its importation. The Wildlife Fund supports grants for State wildlife programs. Expenditures from the Fund are made pursuant to a permanent 1951 appropriation.

8. A total tax rate of 18.4 cents per gallon is imposed on gasoline and special motor fuels used in motorboats. Of this rate, 0.1 cent per gallon is dedicated to the Leaking Underground Storage Tank Trust Fund. Of the remaining 18.3 cents per gallon, 11.5 cents per gallon (through 1 October 2001), is transferred to the Aquatic Resources Trust Fund. These transfers are scheduled to increase to 13 cents per gallon (1 October 2001 to 30 September 2003) and 13.5 cents per gallon (1 October 2003 to 30 September 2005), after which time no transfers will occur. Tax collected in excess of these amounts is retained in the General Fund of the Treasury. The motorboat gasoline and special motor fuels taxes are collected under the same rules as apply to the Highway Trust Fund excise taxes on those fuels. 


\section{Item}

Bows having a draw weight of 10 lbs or more

Arrow components (shafts, point, nocks, and vanes) for arrows 18" or more in length (or suitable for use with a taxable bow, if shorter)

Pistols and revolvers

Firearms other than pistols and revolvers

Shells and cartridges

\section{Tax rate}

11 per cent of mfr's price 12.4 per cent of mfr's price

10 per cent of mfr's price

11 per cent of mfr's price

11 per cent of mfr's price

Separate General Fund excise taxes are imposed on the making or transfer of "non-regular" firearms or explosive devices such as bombs, grenades, small rockets, and mines, sawed-off shotguns or rifles, silencers, and certain concealable weapons.

\section{Non-regular firearms occupational taxes}

In addition to excise taxes on the manufacture and transfer of non-regular firearms, present law imposes annual occupational excise taxes on importers and manufacturers ( $\$ 1000$ per year per premise) of and on dealers ( $\$ 200$ per transfer) of these weapons. ${ }^{9}$ These taxes are administered by the Bureau of Alcohol, Tobacco, and Firearms (the "BATF") in conjunction with non-tax Federal firearms laws.

\section{F. Black lung trust fund excise tax}

A $\$ 1.10$ per ton excise tax is imposed on coal mined in the United States from underground mines. The rate is 55 cents per ton for coal mined in surface mining operations. The tax cannot exceed 4.4 per cent of the coal's selling price. No tax is imposed on lignite.

The coal excise tax rates are scheduled to decline to 50 cents per ton for underground-mined coal and 25 cents per ton for surface-mined coal on 1 January 2014 or any earlier 1 January on which there is no balance of repayable advances from the Black Lung Trust Fund to the General Fund.

\section{G. Communications excise tax}

A 3 per cent Federal excise tax is imposed on amounts paid for communications services. Communications services are defined as "local telephone service", "toll telephone service" and "teletypewriter exchange service". ${ }^{10}$

Local telephone service is the provision of voice quality telephone access to a local telephone system that provides access to substantially all persons having telephone stations constituting a part of the system. Toll telephone service is defined as telephonic ("voice") quality communication for which $(i)$ there is a toll charge that varies with the distance and elapsed transmission time of each individual call and payment for which occurs in the United States or (ii) a service (such as WATS service) which, for a flat periodic charge, entitles the subscriber to an unlimited number of telephone calls to or from an area outside the subscriber's local system area.

9. The taxable period is 1 July through 30 June.

10. Teletypewriter exchange service refers to a data system that is understood to be no longer in use. 
The person paying for the service (i.e. the consumer) is liable for payment of the tax. Service providers are required to collect the tax, however, if a consumer refuses to pay, the service provider is not liable for the tax and is not subject to penalty for failure to collect if reasonable efforts to collect have been made. Instead, the service provider must report the delinquent consumer's name and address to the Treasury Department, which then must attempt to collect the tax.

Special rules, enacted in 1997, apply to the sale of "prepaid telephone cards". These cards are subject to tax when they are sold by a telecommunications carrier to a non-carrier (e.g. a retail store) rather than when communications services are provided to the consumer. The base to which the tax is applied is the face amount of the card. The non-carrier is responsible for paying the tax to the carrier.

Present law exempts numerous types of service from one or both of the tax on local service or toll service. Examples of these exemptions are private communications services (from the tax on local service), news and other public press organisations (from the tax on toll service), use by certain charitable organisations and States and local governments, and radio and broadcast networks (from the tax on toll service).

\section{H. Ozone-depleting chemicals excise tax}

An excise tax is imposed on ozone-depleting chemicals sold or used in the United States. The tax is determined by multiplying a base tax amount (which changes annually) by the specific chemical's ozone-depleting chemicals are subject to the tax.

The excise tax also applies to imported products that were manufactured using chemicals that would have been taxable had the manufacture occurred in the United States (e.g. imported electronic products the manufacture of which involves chemical "washes"). In the case of imported products, the tax equals the tax that would have been imposed on the chemicals used in the manufacture had the activity occurred in the United States unless the taxpayer demonstrates that a different process resulting in less tax was used.

\section{Alcohol excise taxes}

\section{Taxes on alcoholic beverages}

Separate excise taxes are imposed on distilled spirits, wine, and beer. Both the tax rates and the volumetric measures on which the taxes are imposed differ depending on the type of beverage. 
ECO/WKP(2001)39

The tax rates are shown below:

\begin{tabular}{|c|c|}
\hline Beverage & Tax Rate \\
\hline Distilled spirits & $\$ 13.50$ per proof gallon ${ }^{1}$ \\
\hline $\begin{array}{l}\text { Wine: }^{2} \\
\text { Still wines: } \\
\text { No more than } 14 \text { per cent alcohol } \\
\text { More than } 14 \text { percent but not more than } 21 \text { per cent } \\
\text { More than } 21 \text { per cent but not more than } 24 \text { per cent } \\
\text { More than } 24 \text { per cent alcohol } \\
\text { Hard apple cider }\end{array}$ & $\begin{array}{l}\$ 1.07 \text { per wine gallon } \\
{ }^{3} \\
\$ 1.57 \text { per wine gallon } \\
\$ 3.15 \text { per wine gallon } \\
\text { Taxed at the distilled spirits rate } \\
\$ 0.226 \text { per wine gallon }\end{array}$ \\
\hline $\begin{array}{l}\text { Sparkling wines: } \\
\text { Champagne and other naturally } \\
\text { Sparkling wines } \\
\text { Artificially carbonated wines }\end{array}$ & $\begin{array}{l}\$ 3.40 \text { per wine gallon } \\
\$ 3.30 \text { per wine gallon }\end{array}$ \\
\hline Beer & $\$ 18.00$ per barrel (31 gallons) generally ${ }^{4}$ \\
\hline
\end{tabular}

1. A proof gallon is a US liquid gallon consisting of 50 per cent alcohol.

2. Domestic wineries having aggregate annual production not exceeding 250000 gallons are entitled to a tax credit equal to 90 cents per gallon (the amount of the wine tax increase enacted in 1990) on the first 100000 gallons of wine (other than champagne and other sparkling wines) removed in a calendar year. The credit is phased out by 1 per cent for each 1000 gallons produced in excess of 150000 gallons. The credit reduces the effective tax rate on these wines from $\$ 1.07$ per wine gallon to $\$ 0.17$ per wine gallon (the rate that applied before 1990 when the credit was enacted). The credit has been the subject of a challenge under the General Agreement on Trade and Tariffs ("GATT"). Hard apple cider production from "small" domestic wineries, defined as above, receives a credit of 5.6 cents per gallon of cider produced. Production of hard apple cider and other wines eligible for the small winery production credit is aggregated in applying the per-winery volume limits of the credit. (This credit rate produces the same effective tax rate on hard apple cider produced by small wineries as is imposed on other still wines having an alcohol content of more than 14 per cent).

3. A wine gallon is a US liquid gallon, without regard to alcoholic content.

4. The $\$ 18$ per barrel rate equals approximately 58 cents per gallon. The tax rate is $\$ 7$ per barrel (approximately 22.6 cents per gallon) on the first 60000 barrels of beer removed each year by domestic brewers producing less than 2 million barrels of beer during the calendar year. This reduced rate provision was the subject of a GATT challenge.

Liability for these taxes arises when the beverage is produced or imported. Under the current bonded production facility system, payment generally is due on removal of the domestically produced beverages from the facility where produced. Foreign alcoholic beverages that are bottled before importation are taxed on removal from the first US warehouse into which they are entered. Foreign alcoholic beverages that are imported in bulk and transferred to a domestic facility for bottling are taxed as if domestically produced.

Present law includes a tax credit that reduced the effective tax rate on alcohol in a distilled spirits product that is derived from fruit to the lower, wine tax rates. There is no requirement that the "wine" be produced from any particular type of fruit or that wine colouring or that wine flavouring be evident in the distilled spirits product. For example, it is understood that some of the "wine" with respect to which the credit currently is claimed is produced from table grapes, oranges, and grapefruits and that, in some cases, the wine is filtered to eliminate both colour and flavouring. There is no limit other than Federal alcoholic beverage product labelling rules on the amount of a distilled spirits product that may be comprised of this fruit-derived alcohol. Additionally, present law includes a separate tax credit that eliminates the distilled spirits tax on certain "flavourings" added to distilled spirits products.

Annual occupational taxes are imposed on each premise of alcoholic beverage producers, wholesale distributors, and retailers. Additionally, occupational taxes are imposed on proprietors of 
facilities using alcohol for nonbeverage or industrial uses. These taxes are payable annually, for the twelve-month period from 1 July through 30 June. The tax rates are shown below.

\begin{tabular}{ll}
\hline Tax & Tax rate \\
\hline Producers & $\$ 1000$ per year \\
Wholesale distributors & $\$ 500$ per year \\
Retailers & $\$ 250$ per year \\
Distilled spirits non-beverage use facilities & \$500 per year \\
Distilled spirits industrial use facilities & $\$ 250$ per year \\
\hline
\end{tabular}

1. The tax rate is $\$ 500$ per year per premise for businesses with gross receipts of less than $\$ 500000$ in the preceding taxable year. Certain small alcohol fuel (e.g. ethanol) producers are exempt from the tax.

\section{J. Tobacco excise taxes}

\section{Tobacco products taxes}

Excise taxes are imposed on cigarettes and a variety of other tobacco products. The taxes are imposed on removal of the products by a manufacturer, or in the case of products manufactured in other countries, when the products are imported or brought into the United States.

The taxable products and tax rates are shown below:

\begin{tabular}{|c|c|c|}
\hline Product & & ate \\
\hline \multicolumn{3}{|l|}{ Cigarettes: } \\
\hline Small cigarettes ${ }^{1}$ & $\$ 17 / 1000^{3}$ & $\$ 19.50 / 1000$ \\
\hline Large cigarettes ${ }^{2}$ & $\$ 35.70 / 1000$ & $\$ 40.95 / 1000$ \\
\hline \multicolumn{3}{|l|}{ Cigars: ${ }^{4}$} \\
\hline Small cigars & $\$ 1.594 / 1000$ & $\$ 1.828 / 1000$ \\
\hline Large cigars & $\begin{array}{l}\text { 18.063per cent of mfr. price } \\
\text { but not over } \$ 32.50 / 1000\end{array}$ & $\begin{array}{l}20.719 \text { per cent of mfr. price } \\
\text { but not over } \$ 48.75 / 1000\end{array}$ \\
\hline \multicolumn{3}{|l|}{ Smokeless tobacco: } \\
\hline Snuff & $\$ 0.51 / \mathrm{lb}$ & $\$ 0.585 / 1000$ \\
\hline Chewing tobacco & $\$ 0.17 / \mathrm{lb}$ & $\$ 0.195 / 1000$ \\
\hline $\begin{array}{l}\text { Pipe tobacco and "roll your own" } \\
\text { tobacco: }\end{array}$ & $\$ 0.9567 / \mathrm{lb}$ & $\$ 1.0969 / \mathrm{lb}$ \\
\hline Cigarette papers & $\begin{array}{l}\$ 0.0106 / \mathrm{pkg} \text { of } 50 \text { papers } \\
\text { or part thereof }\end{array}$ & $\begin{array}{l}\$ 0.0122 / \mathrm{pkg} \text { of } 50 \text { papers } \\
\text { or part thereof }\end{array}$ \\
\hline Cigarette tubes & $\begin{array}{l}\$ 0.213 / \mathrm{pkg} \text { of } 50 \text { papers } \\
\text { or part thereof }\end{array}$ & $\begin{array}{l}\$ 0.0244 / \mathrm{pkg} \text { of } 50 \text { papers } \\
\text { or part thereof }\end{array}$ \\
\hline
\end{tabular}

1. Small cigarettes are cigarettes weighing no more that three pounds per thousand. Virtually all tobacco excise tax revenues are derived from the tax on small cigarettes.

2. Large cigarettes are cigarettes weighing more than three pounds per thousand. Large cigarettes (measuring more than 6.5 inches in length) are taxed at the rate prescribed for small cigarettes, counting each 2.75 inches (or fraction thereof) as one cigarette.

3. This rate equals 34 cents per pack of 20 cigarettes. The increased rate scheduled to take effect in 2002 equals 39 cents per pack of 20 cigarettes.

4. Small and large cigars are distinguished by weight, with the same three-pound break point as cigarettes. Most taxable cigars are large cigars. 


\section{Tobacco occupational tax}

Manufacturers and exporters of taxable tobacco products (including cigarette papers and tubes) are subject to an annual occupational excise tax of $\$ 1000$ per year per premise. The tax rate is reduced to $\$ 500$ per year, per premise for businesses with gross receipts of less than $\$ 500000$ in the preceding taxable year. The occupational tax is imposed with respect to the twelve month period from 1 July through 30 June. This tax is part of a larger system of Federal regulation of tobacco manufacturers and exporters. Among the Federal regulations are requirements that these parties receive permits to conduct business and post bonds as necessary to ensure payment of relevant tobacco products excise taxes.

\subsection{State indirect tax rates}

Tax rates: Although state tax rates range from 3 per cent to 7 per cent, they are clustered fairly narrowly in the range of 5 to 6.5 per cent; 30 state tax rates fall within this range (see Table A2). In about two-thirds of the states that levy general sales taxes, local governments also levy sales taxes, commonly as surcharges on the state tax. While the most common practice is for municipalities or counties to levy local sales taxes, in some states special districts (commonly transit districts) also levy sales taxes. Combined state and local sales tax rates reach 8 per cent or higher in several states such as Alabama, California, Louisiana, New York and Texas.

Table A2. Some state tax rates

\begin{tabular}{|c|c|c|c|c|c|}
\hline General sales and use tax rate & $\begin{array}{l}\text { Number of } \\
\text { states }\end{array}$ & $\begin{array}{c}\text { Gasoline tax } \\
\text { (cents per gallon) }\end{array}$ & $\begin{array}{l}\text { Number of } \\
\text { states }\end{array}$ & $\begin{array}{c}\text { Cigarette tax } \\
\text { (cents per 20-pack) }\end{array}$ & $\begin{array}{c}\text { Number of } \\
\text { states }\end{array}$ \\
\hline 0 per cent & 5 & $4-8$ & 4 & $1-7$ & 5 \\
\hline 3 per cent $-<4$ per cent & 2 & $10-16$ & 9 & $12-20$ & 10 \\
\hline 4 per cent $-<5$ per cent & 13 & $17-20$ & $17^{1}$ & $21-28$ & 7 \\
\hline 5 per cent $-<6$ per cent & 16 & $21-23$ & $10^{2}$ & $30-36$ & 7 \\
\hline \multirow[t]{5}{*}{6 per cent -7 per cent } & 15 & $>23$ & 9 & $41-48$ & 4 \\
\hline & & & & $50-59$ & 6 \\
\hline & & & & $65-68$ & 3 \\
\hline & & & & $71-76$ & 4 \\
\hline & & & & $>80$ & $5^{3}$ \\
\hline
\end{tabular}

1. It includes one state with 20.5 cents per gallon.

2. It includes one state with 23.1 cents per gallon.

3. It includes two states with 100 cents per 20-pack.

Source: http://www.taxfoundation.org/statefinance.html. 


\section{ECONOMICS DEPARTMENT}

\section{WORKING PAPERS}

312. Product and Labour Markets Interactions in OECD Countries (December 2001) Giuseppe Nicoletti, Andrea Bassanini, Ekkehard Ernst, Sébastien Jean, Paulo Santiago and Paul Swaim

311. Modelling Import Responsiveness for OECD Manufactures Trade (October 2001) Mara Meacci and David Turner

310. Trade Linkages and the Trade Matrices in the OECD Interlink Model (October 2001) Laurence Le Fouler, Wim Suyker and Dave Turner

309. Encouraging Environmentally Sustainable Growth in Australia (October 2001) Ann Vourc'h and Robert Price

308. Financial Market Liberalisation, Wealth and Consumption (September 2001) Laurence Boone, Nathalie Girouard and Isabelle Wanner

307. The Economic Integration of Germany's New Länder (September 2001) Eckhard Wurzel

306. Standard Shocks in the OECD Interlink Model (September 2001) Thomas Dalsgaard, Christophe André and Pete Richardson

305. Fiscal Implications of Ageing: Projections of Age-related Spending (September 2001) Thai Thanh Dang, Pablo Antolin and Howard Oxley

304. The Width of the Intra-European Economic Borders (August 2001) Alain de Serres, Peter Hoeller and Christine de la Maisonneuve

303. Surveillance of Tax Policies: A Synthesis of Findings in Economic Surveys (July 2001) Paul van den Noord and Christopher Heady

302. Reforming the Tax System in Portugal (July 2001) Chiara Bronchi, José C. Gomes-Santos

301. Tax Systems in European Union Countries (June 2001) Isabelle Joumard

300. Encouraging Environmentally Sustainable Growth in Belgium (June 2001) Paul O’Brien, David Carey, Jens Høj, Andreas Woergoetter

299. Encouraging Environmentally Sustainable Growth in Poland (June 2001) Grzegorz Peszko, Patrick Lenain

298. Tracking the Euro (June 2001) Vincent Koen, Laurence Boone, Alain de Serres, Nicola Fuchs

297. Firm Dynamics and Productivity Growth: A Review of Micro-evidence from OECD Countries (June 2001) Sanghoon Ahn

296. How should Norway Respond to Ageing? (May 2001) Pablo Antolín and Wim Suyker 
295. How will Ageing Affect Finland?

(May 2001) Pablo Antolín, Howard Oxley and Wim Suyker

294. Sectoral Regulatory Reforms in Italy: Framework and Implications

(May 2001) Alessandro Goglio

293. Encouraging Environmentally Sustainable Growth: Experience in OECD Countries (May 2001) Paul O'Brien and Ann Vourc'h

292. Increasing Simplicity, Neutrality and Sustainability: A Basis for Tax Reform in Iceland (May 2001) Richard Herd and Thorsteinn Thorgeirsson

291. Options for Reforming the Tax System in Greece (April 2001) Chiara Bronchi

290. Encouraging Environmentally Sustainable Growth in Canada (March 2001) Ann Vourc'h

289. Encouraging Environmentally Sustainable Growth in Sweden (March 2001) Deborah Roseveare

288. Public Spending in Mexico: How to Enhance its Effectiveness (March 2001) Bénédicte Larre and Marcos Bonturi

287. Regulation in Services: OECD Patterns and Economic Implications (February 2001) Giuseppe Nicoletti

286. A Small Global Forecasting Model (February 2001) David Rae and David Turner

285. Managing Public Expenditure: Some Emerging Policy Issues and a Framework for Analysis (February 2001) Paul Atkinson and Paul van den Noord

284. Trends in Immigration and Economic Consequences (February 2001) Jonathan Coppel, Jean-Christophe Dumont and Ignazio Visco

283. Economic Growth: The Role of Policies and Institutions. Panel Data Evidence from OECD Countries (January 2001) Andrea Bassanini, Stefano Scarpetta and Philip Hemmings

282. Does Human Capital Matter for Growth in OECD Countries? Evidence from Pooled Mean-Group Estimates (January 2001) Andrea Bassanini and Stefano Scarpetta

281. The Tax System in New Zealand: An Appraisal and Options for Change (January 2001) Thomas Dalsgaard

280. Contributions of Financial Systems to Growth in OECD Countries (January 2001) Michael Leahy, Sebastian Schich, Gert Wehinger, Florian Pelgrin and Thorsteinn Thorgeirsson

279. House Prices and Economic Activity (January 2001) Nathalie Girouard and Sveinbjörn Blöndal

278. Encouraging Environmentally Sustainable Growth in the United States (January 2001) Paul O’Brien 